\title{
2011 Annual Criticality Safety Program Performance Summary
}

December 2011

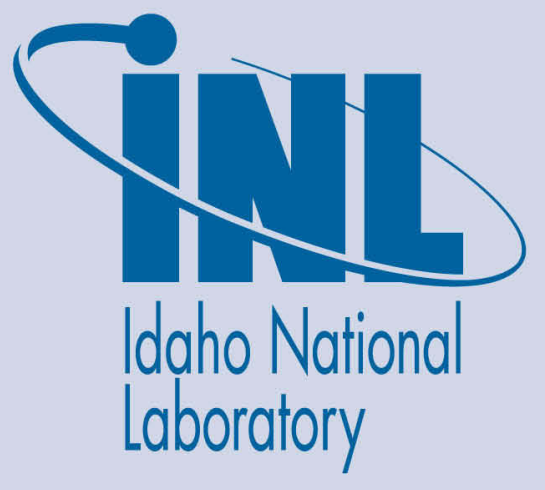

The INL is a U.S. Department of Energy National Laboratory operated by Battelle Energy Alliance 
INL/EXT-11-23919

IAS 1236

\title{
2011 Annual Criticality Safety Program Performance Summary
}

December 2011

\author{
Idaho National Laboratory \\ Idaho Falls, Idaho 83415
}

http://www.inl.gov

\author{
Prepared for the \\ U.S. Department of Energy \\ Office of Nuclear Energy \\ Under DOE Idaho Operations Office \\ Contract DE-AC07-05ID14517
}




\section{DISCLAIMER}

This information was prepared as an account of work sponsored by an agency of the U.S. Government. Neither the U.S. Government nor any agency thereof, nor any of their employees, makes any warranty, expressed or implied, or assumes any legal liability or responsibility for the accuracy, completeness, or usefulness, of any information, apparatus, product, or process disclosed, or represents that its use would not infringe privately owned rights. References herein to any specific commercial product, process, or service by trade name, trade mark, manufacturer, or otherwise, does not necessarily constitute or imply its endorsement, recommendation, or favoring by the U.S. Government or any agency thereof. The views and opinions of authors expressed herein do not necessarily state or reflect those of the U.S. Government or any agency thereof. 


\section{Annual Criticality Safety Program \\ Performance Summary}

Approved by:

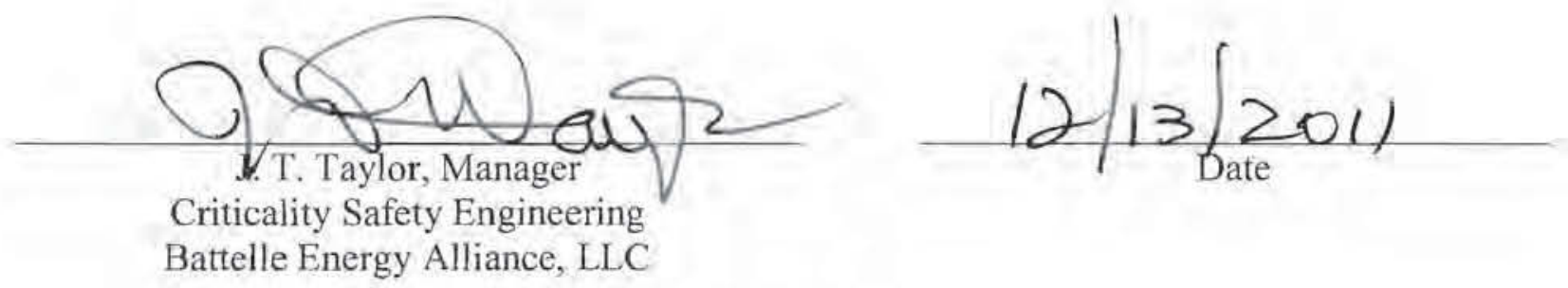


IAS 1236

INL/EXT-11-23919

Page $i$ of iv

\section{Summary}

The 2011 review of the INL Criticality Safety Program has determined that the program is robust and effective. The review was prepared for, and fulfills Contract Data Requirements List (CDRL) item H.20, "Annual Criticality Safety Program performance summary that includes the status of assessments, issues, corrective actions, infractions, requirements management, training, and programmatic support." This performance summary addresses the status of these important elements of the INL Criticality Safety Program.

Assessments - Assessments in 2011 were planned and scheduled. The scheduled assessments included a Criticality Safety Program Effectiveness Review, Criticality Control Area Inspections, a Protection of Controlled Unclassified Information Inspection, an Assessment of Criticality Safety SQA, and this management assessment of the Criticality Safety Program. All of the assessments were completed with the exception of the "Effectiveness Review" for SSPSF, which was delayed due to emerging work.

Although minor issues were identified in the assessments, no issues or combination of issues indicated that the INL Criticality Safety Program was ineffective. The identification of issues demonstrates the importance of an assessment program to the overall health and effectiveness of the INL Criticality Safety Program.

Issues and Corrective Actions - There are relatively few criticality safety related issues in the Laboratory ICAMS system. Most were identified by Criticality Safety Program assessments. No issues indicate ineffectiveness in the INL Criticality Safety Program. All of the issues are being worked and there are no imminent criticality concerns.

Infractions - There was one criticality safety related violation in 2011. On January 18, 2011, it was discovered that a fuel plate bundle in the Nuclear Materials Inspection and Storage (NMIS) facility exceeded the fissionable mass limit, resulting in a technical safety requirement (TSR) violation. The TSR limits fuel plate bundles to 1085 grams U-235, which is the maximum loading of an ATR fuel element. The overloaded fuel plate bundle contained 1097 grams U-235 and was assembled under an 1100 gram U-235 limit in 1982. In 2003, the limit was reduced to 1085 grams citing a new criticality safety evaluation for ATR fuel elements. The fuel plate bundle inventories were not checked for compliance prior to implementing the reduced limit. A subsequent review of the NMIS inventory did not identify further violations.

Requirements Management - The INL Criticality Safety program is organized and well documented. The source requirements for the INL Criticality Safety Program are from 10 CFR 830.204, DOE Order 420.1B, Chapter III, "Nuclear Criticality Safety," ANSI/ANS 8-series Industry Standards, and DOE Standards. These source requirements are documented in LRD-18001, "INL Criticality Safety Program Requirements Manual."

The majority of the criticality safety source requirements are contained in DOE Order 420.1B because it invokes all of the ANSI/ANS 8-Series Standards. DOE Order 420.1B also invokes several DOE Standards, including DOE-STD-3007, "Guidelines for Preparing Criticality Safety Evaluations at Department of Energy Non-Reactor Nuclear Facilities." 
IAS 1236

INL/EXT-11-23919

Page ii of iv

DOE Order 420.1B contains requirements for DOE "Heads of Field Elements" to approve the criticality safety program and specific elements of the program, namely, the qualification of criticality staff and the method for preparing criticality safety evaluations. This was accomplished by the approval of SAR-400, "INL Standardized Nuclear Safety Basis Manual," Chapter 6, "Prevention of Inadvertent Criticality." Chapter 6 of SAR-400 contains sufficient detail and/or reference to the specific DOE and contractor documents that adequately describe the INL Criticality Safety Program per the elements specified in DOE Order 420.1B. The Safety Evaluation Report for SAR-400 specifically recognizes that the approval of SAR-400 approves the INL Criticality Safety Program.

No new source requirements were released in 2011. A revision to LRD-18001 is planned for 2012 to clarify design requirements for criticality alarms.

Training - Criticality Safety Engineering has developed training and provides training for many employee positions, including fissionable material handlers, facility managers, criticality safety officers, firefighters, and criticality safety engineers. Criticality safety training at the INL is a program strength. A revision to the training module developed in 2010 to supplement MFC certified fissionable material handlers (operators) training was prepared and presented in August of 2011. This training, "Applied Science of Criticality Safety," builds upon existing training and gives operators a better understanding of how their criticality controls are derived. Improvements to 00INL189, "INL Criticality Safety Principles" are planned for 2012 to strengthen fissionable material handler training. Criticality Safety Engineering assisted the Training Directorate in developing fissionable material handler training at SSPSF. Facility specific training on new and existing criticality controls was provided by Criticality Safety Engineering to operators in classroom settings for FCF, FMF, HFEF, TREAT and ZPPR.

Programmatic Support - The major activity/deliverable of the INL Criticality Safety Engineering Department is performing criticality safety evaluations (CSEs) to support work. CSEs derive administrative and engineered criticality safety controls and limits. The CSEs support changes to Documented Safety Analyses (DSAs) and Criticality Control Lists that provide the specific criticality safety controls for fissionable material activities allowed in a facility. Seventeen CSEs and fifteen revisions to Criticality Control Lists were completed in support of INL activities. In addition to producing these technical reports, all DSA revisions and upgrades were reviewed by criticality safety personnel to ensure that CSEs were used correctly.

The Criticality Safety Engineering Department hired two recent graduates in 2010 and used two subcontractors in early 2011. One of those engineers left the INL in 2011. The current staffing level is projected to be adequate for the projected 2012 work-load. 
IAS 1236

INL/EXT-11-23919

Page iii of iv

New Issues Identified in this Management Assessment:

1) Criticality Safety Training (INL1126) for INL Emergency Responders was developed in 2007. An area for improvement was identified to incorporate comments/improvements received on the training and its companion study guide (INL/EXT-07-12535).

2) The existing training plan for Criticality Safety Engineers assumes a certain level of experience and is not adequate for engineers out of college. The qualification needs to be strengthened to help new engineers realize expectations. 
IAS 1236

INL/EXT-11-23919

Page iv of iv

This page intentionally blank 
IAS 1236

INL/EXT-11-23919

Page 1 of 16

\section{Introduction}

The purpose of the Criticality Safety Program is to ensure appropriate actions are taken to prevent and mitigate the consequences of a criticality accident. The requirements of the Criticality Safety Program are documented in Laboratory Requirements Document, LRD-18001, "INL Criticality Safety Program Requirements Manual." LRD-18001 complies with the requirements of 10 CFR 830.204, applicable DOE Orders/Standards, and the ANSI/ANS-8-Series Standards.

A mature and effective criticality safety program requires the involvement of multiple organizations. These organizations include Criticality Safety, Emergency Management, Engineering, Fire Protection, Nuclear Operations, Safety Analysis, Safeguards \& Security, and Training. Because of this multi-organizational involvement, the INL Criticality Safety Program relies on, and is part of the Integrated Safety Management System (ISMS). The Laboratory ISMS Program, which includes Criticality Safety, is documented in PDD-1004, "Integrated Safety Management System." The Criticality Safety Program is, in fact, based on the core functions and guiding principles of ISMS.

Management defines the scope of work. The Criticality Safety Engineering Department works with line management to analyze the hazards and develop controls for the prevention and mitigation of a criticality accident. Criticality safety evaluations (CSEs) are performed that identify and document controls. Criticality Safety Engineering assists line management in the implementation of controls and has a program in place to provide feedback and continuous improvement, which includes assessments and lessons learned.

The Criticality Safety Program is built on the first principle of ISMS, "line management is responsible for safety." A strength of the INL Criticality Safety Program is that line management owns, accepts, understands and participates in the criticality safety of their operations and facilities. Criticality Safety Engineering is responsible for developing and documenting the requirements for the INL Criticality Safety Program, but the real owners of the program are facility ("line") management.

The Criticality Safety Program (LRD-18001) clearly defines Laboratory, line management, and criticality safety engineering responsibilities. LRD-18001 also contains the requirements for process evaluation and analysis. CSEs are prepared, reviewed and approved per Laboratory procedures, mainly NS-18201, "Performing and Reviewing Criticality Safety Evaluations." Requirements for fissionable material control and operational procedures are also described in LRD-18001.

The Criticality Safety Program describes the training requirements for fissionable material handlers that meet the requirements of ANSI/ANS-8.20, "Nuclear Criticality Safety Training." The Criticality Safety Program contains specific training and qualification for criticality safety engineers, facility managers, fissionable material handlers, and Criticality Safety Officers (CSOs). 
IAS 1236

INL/EXT-11-23919

Page 2 of 16

Annual and periodic criticality safety assessments and reviews are performed to ascertain that process conditions have not changed to affect applicable CSEs. The Criticality Safety Program requires these assessments are performed per Laboratory procedures, mainly NS-18202, "Criticality Safety Assessments." These procedures address the response to deficiencies, control violations and infractions.

Implementation of the INL Criticality Safety Program ensures that all operations with the potential for criticality have controls in place to prevent and mitigate the consequence of accidental criticality.

\section{Description}

This performance summary addresses the status of the following important elements of the INL Criticality Safety Program and fulfills Contract Data Requirements List (CDRL) requirement H.20, "Annual Criticality Safety Program performance summary that includes the status of assessments, issues, corrective actions, infractions, requirements management, training, and programmatic support." Each area is addressed in the following sections with supporting information included as appropriate.

Assessments - plans, schedules, and results.

Issues and Corrective Actions - significant issues and status.

Infractions - discussion of any criticality safety control or limit violation and status of corrective actions.

Requirements Management - status of contractual requirement implementation.

Training - adequacy of training and qualification.

Programmatic Support - criticality safety evaluations and technical guidance performed in support of INL goals and milestones. 
IAS 1236

INL/EXT-11-23919

Page 3 of 16

\section{Assessments}

\section{CY 2011}

Several criticality safety assessments were performed in 2011. Contractor assessments were scheduled in the Laboratory Integrated Assessment Schedule (IAS) database, which is shown in the Appendix. The scheduled assessments included a Criticality Safety Program Effectiveness Review (IAS11711), Criticality Control Area Inspections (IAS11702), a Protection of Controlled Unclassified Information inspection (IAS11714), an Assessment of Criticality Safety SQA (IAS111705), and this management assessment of the Criticality Safety Program (IAS1236).

Quarterly assessments were performed by DOE-ID. The DOE Quarterly assessments use elements from DOE-STD-1158, "Self-Assessment Standard for DOE Contractor Criticality Safety Programs" and other lines of inquiry. These lines of inquiry are mainly programmatic in nature and derived from ANSI/ANS-8.1, "Nuclear Criticality Safety in Operations with Fissionable Material Outside Reactors" and 8.19, "Administrative Practices for Nuclear Criticality Safety". No significant criticality safety issues were identified in the 2011 DOE-ID quarterly assessments.

\section{Criticality Safety Program Effectiveness Review}

The "Program Effectiveness" assessment (IAS11711) was planned to use LRD-18001, "INL Criticality Safety Program Requirements Manual," for lines of inquiry. LRD-18001 includes all regulatory requirements from the CFR, DOE Orders/Standards, and ANSI/ANS Standards (see the Requirement Management section). The "Program Effectiveness" assessment (IAS11711) was planned for the Space and Security Power Systems Facility (SSPSF) at MFC. The SSPSF was designated because a new upgraded DSA (SAR-408) was submitted to DOE-ID in September 2009 for review and approval, and was implemented in June of 2011. The purpose of the assessment was to determine the effectiveness of the criticality safety program at the SSPSF. Benefits from the assessment include line management becoming more knowledgeable of the processes that implement the criticality safety program. Another benefit derived from the Program Effectiveness assessment is that it provides an opportunity for Criticality Safety Engineering to improve LRD-18001, i.e., reinforcing requirements and Best Management Practices that may need to be improved. The assessment will identify criticality safety requirements applicable to SSPSF operations and the programs and systems that implement the requirements, ensuring that these programs are not eroded or lost. IAS11711 is scheduled to be complete December 15, 2011, however conflicting priorities have delayed the start of this assessment.

\section{Criticality Control Area Inspections}

The purpose of the annual Criticality Control Area (CCA) Inspections (IAS11702) is to ensure that process conditions have not been altered to affect the criticality safety evaluations. These inspections are required by ANSI/ANS 8.1, "Nuclear Criticality Safety in Operations with 
IAS 1236

INL/EXT-11-23919

Page 4 of 16

Fissionable Material Outside Reactors" and 8.19, "Administrative Practices for Nuclear Criticality Safety." The inspections also include compliance to LWP-18003, "Establishing, Operating and Deleting CCAs" and were performed according to NS-18202, "Criticality Safety Assessments," and LWP-13740, "Performing Inspections and Surveillances," and documented on checklists (Form 431.03). There are currently 26 CCAs and all but NRAD were walked down. No conditions were identified that would invalidate a criticality safety evaluation (see Inspection information in the Appendix). Observations corrected immediately included information updates to the CCA master-list such as updating names of CSOs/alternates and CCA Line Managers. Issues identified were entered into the ICAMS and include:

(1) The inspection at HFEF (CSI11102) determined that a Mass limit CCA located in room 125 within the HFEF Procedure CCA, be eliminated because the majority of the fissionable material has been transferred to another CCA at MFC. Elimination of the CCA required a revision to the HFEF CHCS document, HFEF-OI-1020, which was submitted to HFEF for review, and issued.

(2) Criticality Safety Engineering made a recommendation at CITRC CCAs (CSI11105) that the Laboratory Instruction (LI) for work in this CCA be revised to reflect moderated fissionable equivalent (MFE), which was implemented in several INL facilities in 2010. Homeland Security has a project planned, contingent on funding, to conduct detection of fissionable material (DTRA-LEU) using active-interrogation at the SOX range. The MFE definition will have little effect on the current inventory. Criticality Safety has requested to review and approve the LI.

(3) The inspection of FMF (CSI11117) identified the need to better define/address the "no liquid" moderator control for approved storage in LST-386 and derive the need to control special reflectors.

In addition to the facility inspections, IAS11702 also included a review of all Material Balance Areas to determine whether facilities that contain greater than 15 grams of fissionable material should be designated as CCAs. The MBA information provided a list of fissionable material, custodians, facility, building and location for the following areas: ATR Complex (includes CFA, IF town facilities and CITRC), MFC and PBF. As a result of this review, all MBAs were reviewed. An MBA at CFA-625 containing radioactive sources stored in a cargo container used for research experiments was re-evaluated. The material inventory was previ ously eval uated in 2008 ( $Л T-11-08$ ) and was again determined that a CCA is not necessary per LRD-18001 and LWP-18003 requirements. The MBA review determined that there were no areas containing greater than 15 grams of fissionable material that should be designated as CCAs. The results of the CCA inspections are included in the "Assessments" section of the Appendix.

\section{Criticality Safety Software Quality Assurance}

Criticality Safety Software Quality Assurance was assessed (IAS111705) per LWP-13620, "Software Quality Assurance." The assessment used Form 220.25, which contains 18 lines of inquiry. These included training, configuration control, verification activities and process improvements. The assessment determined that the Criticality Safety Engineering Software is compliant to Laboratory Requirements. Process improvements identified included several 
IAS 1236

INL/EXT-11-23919

Page 5 of 16

editorial improvements to the software quality assurance plan, NS-18211, "Criticality Safety Analysis Software," the procurement of uninterruptible power supplies and another network attached storage device. The completed checklist is attached in the "Assessments" section.

\section{Protection of Controlled Unclassified Information}

Protection of Controlled Unclassified Information was assessed via an inspection (IAS11714) per LWP-11202, "Controlled Unclassified Information Program." The assessment used Form 220.23 for lines of inquiry. A walk-down of the criticality safety area was performed and three organizational members were interviewed. No issues were identified. The completed checklist is attached in the "Assessments" section of the Appendix.

\section{Summary}

The assessments described here were performed according to NS-18202, "Criticality Safety Assessments," and Laboratory procedures such as LWP-13760, "Performing Independent Reviews and Assessments." NS-18202 was revised and issued in October of 2011.

Although several issues were identified in the above described assessments, no issues or combination of issues indicate an ineffective Criticality Safety Program. The assessments show that an assessment program is important to the overall health and effectiveness of the INL Criticality Safety Program. 
IAS 1236

INL/EXT-11-23919

Page 6 of 16

\section{Issues and Corrective Actions}

A search of the Laboratory Issues and Corrective Action Management System (ICAMS) was performed for criticality safety related issues to determine trends or areas of weakness. The search looked for Issues/Observations (IOs) that were either "open" or "closed" in CY2011. The criticality safety related issues and corrective action items in ICAMS are summarized here and listed in the "Issues and Corrective Actions" section of the Appendix. The listing in the appendix includes all criticality safety related 2011 issues and action items (open and closed) with ICAM number, title, description, and status.

There are relatively few criticality safety related issues in the ICAMS system. Most issues are actively being resolved. Many of the issues were identified from Criticality Safety Program assessment activities. There are no issues that are an imminent criticality concern. The important issues are discussed below.

(1) Criticality Safety Officer Program. There are two issues that identify improvement in the MFC Criticality Safety Officer (CSO) program, particularly the CSO at HFEF. A new CSO was appointed at HFEF with time available to perform expected roles and responsibilities. An improvement was made to the qualification plan for CSOs (NS-18204) that requires the Criticality Safety Engineering Manager to interview the prospective CSO to validate CSO familiarity/understanding of the facility criticality safety program. Two criticality safety engineers were appointed to assist FCF and HFEF operations personnel in understanding their facility programs. There is one remaining action item that requires the Criticality Safety Manager to meet with MFC CSOs and discuss criticality safety issues. To date, half of the CSOs have been contacted. This action is expected to be complete by the end of CY2011.

(2) Criticality Control Area Issues. Criticality Control Area inspections resulted in areas for improvement at HFEF and FMF. The definition of moderator in the CHCS at HFEF was revised to be specific to hydrogenous liquid. This issue is closed. New missions at FMF and ZPPR will require special reflector controls. A criticality safety evaluation was completed that defines special reflectors. Action items remain open to revise the criticality controls at FMF and ZPPR. These actions are scheduled for closure in early CY2012.

(3) Mass Tracking System (MTG) at FCF. The MTG contains conservative mass factors that are used to conservatively implement controls in the absence of analytical data. An issue was entered to update the conservative mass factor for salt in the MK-V electrorefiner. The processing of FFTF fuel resulted in numerous samples taken of the salt during the campaign and analysis of the samples at the Analytical Laboratory. The analysis demonstrated that the process model accurately predicts the plutonium concentration. Criticality Safety engineering issued a report (TEV-1359) recommending the actions required to reduce the conservative mass factor from 1.1 to 1.0 for plutonium in the MK-V electrorefiner. The action is complete but the mass factor in the MTG has not been modified. 
(4) Criticality Safety Principles Training. "Criticality Safety Principles" is a training model used for fissionable material handlers, criticality safety officers, system engineers, safety analysts, and other disciplines. This web-based training and its companion study guide INL/INT-06-01183 have not been revised since 2006. A review of comments from those who have taken the training and test question performance, has identified areas for improvement. Significant improvements have been made and are in the process of being programmed into the training and study guide. The revisions are expected to be complete in early CY2012.

(5) ATRC Fissionable Material Handler Training. A 2010 review of the ATRC fissionable material handler training identified an area for improvement by creating a unique Lesson Plan for ATRC. The ATRC training was using the documents and scenarios for ATR. A new ATRC specific Lesson Plan was created by ATR training personnel with review and concurrence by Criticality Safety Engineering. This action item is closed.

(6) Response to Criticality Alarms (CASs) at MFC. There are currently four facilities at MFC with CASs - FCF, FMF, TREAT, and ZPPR. The CPP-651 project is currently planning to have a CAS, but it is not yet installed. FCF has been shown to be "well shielded" and the approved "Upgraded" DSA does not require the CAS. Criticality in TREAT has been shown to be "incredible" with the types of materials allowed and implementation of controls. The "Upgraded" DSA for TREAT does not require a CAS. In the very near future there will only be CASs at FMF and ZPPR. The current response to a CAS at MFC is immediate evacuation of the affected facility. An MFC-wide voice announcement states that there is a criticality in the affected facility and directs personnel to evacuate. Affected facility personnel evacuate to a staging area outside the immediate evacuation zone (12 Rad-in-air boundary). The Emergency Action Manager (EAM) activates the ECC. Unaffected personnel are trained to "not approach" the affected facility but are not required to "TAKE SHELTER." Personnel in facilities and buildings with staging areas stage at the appointed area and prepare to evacuate. Nuclear facilities shutdown important equipment/activities, stage at the appointed area and prepare to evacuate. All facilities/buildings that stage do so no matter how close they are to the affected facility. Nuclear Facilities shutdown their facility, stage and prepare to evacuate while personnel outside continue to perform construction work or walk around.

Criticality Safety Engineering recommended that MFC response to a facility criticality alarm include:

a. Immediate evacuation of the affected facility beyond the immediate evacuation zone (12 Rad-in-air boundary).

b. A voice announcement stating that a criticality alarm has occurred in the affected facility (the existing voice announcement is adequate). 
IAS 1236

INL/EXT-11-23919

Page 8 of 16

c. Personnel be trained to avoid the affected facility (the fence around FMF and ZPPR is adequate to protect personnel) - "MFC access training" (MFC00003) should be revised to include this training.

d. Facilities (other, Radiological and Nuclear) determine whether they have processes that need orderly shut-down or curtailment. Criticality Safety Engineering does not believe that ALL facilities should shut-down and stage for evacuation (a requirement for TAKE SHELTER), however there may be some facilities that wish to respond (e.g., SSPSF may wish to stop/shutdown activities/processes for a response to a CAS alarm at ZPPR because of its proximity to ZPPR). Facility Managers should evaluate activities within their facilities and determine their response. "Criticality Alarms at MFC" training (MFC00175) should be revised to be consistent with this approach.

e. No requirement for office/maintenance buildings to stage and prepare for evacuation.

f. A revision to the existing EAL that requires "immediate facility evacuation" and criteria for determining whether a criticality has occurred.

The recommended actions will require a change to the generic EAL for unplanned criticality at MFC and facility specific Emergency Alarm Response procedures. A new EAL has been drafted and is under review. 
IAS 1236

INL/EXT-11-23919

Page 9 of 16

\section{Status of Issues Listed in 2010}

1) Criticality Safety Engineering has not participated in the evaluation of the fissionable material handler training as recommended by LRD-18001, section 3.9. In addition, the criticality accident scenarios are not always a part of the fissionable material handler training as required by LRD-18001. Corrective actions have been identified and listed in ICARE (DR 42158) (Action Items 42230, 31 - 37, 39, 40, 41). This issue predated ICAMS and was issued under the ICARE system. All facility training reviews have been completed.

2) The CSO at HFEF and other MFC facilities does not have adequate resources to perform roles/responsibilities. (IO-004035, Action Item AI-02543). The Criticality Safety Officer (CSO) training was strengthened by requiring the CSO to meet with the Manager of Criticality Safety Engineering to ensure facility familiarization. This item was closed in November of 2010. The final Action Item (AI-02546) to meet with MFC CSOs is scheduled to be closed by December 15, 2011. IO-004035 can then be closed.

3) Revise the HFEF CHCS to change the definition of "moderator" to "liquid moderator" in the next revision. (IO-005849, Action Item AI-02542) The CHCS was revised and this action has been closed (May of 2011). 
IAS 1236

INL/EXT-11-23919

Page 10 of 16

\section{Infractions}

There was one criticality safety violation in 2011 . On January 18,2011 , it was discovered that a fuel plate bundle in the Nuclear Materials Inspection and Storage (NMIS) facility exceeded the fissionable mass limit, resulting in a technical safety requirement (TSR) violation. The TSR limits fuel plate bundles to 1085 grams U-235, which is the maximum loading of an ATR fuel element. ATR fuel plates vary in width and U-235 loading. The overloaded fuel plate bundle contained 1097 grams U-235 and was assembled under an 1100 gram U-235 limit in 1982 at INTEC (CPP-651). In 2003, the limit was reduced to 1085 grams citing a new criticality safety evaluation for ATR fuels. The fuel plate bundle inventories were not checked for compliance prior to implementing the reduced limit. A subsequent review of the NMIS inventory did not identify further violations.

The overloaded fuel plate bundle was repackaged under an existing handling limit into two separate bundles and placed into storage according to TSR loading limits.

See Occurrence Report NE-ID-BEA-ATR-2011-0003, "Nuclear Materials Inspection and Storage (NMIS) Facility Fuel Storage Safety Analysis Report (SAR)-154 Administrative Control Limit Exceeded" included in the Appendix. 
IAS 1236

INL/EXT-11-23919

Page 11 of 16

\section{Requirements Management}

The INL Criticality Safety Program is organized and well documented. Other DOE contractors contact the INL asking for advice and examples of documents demonstrating compliance. The requirements for the INL Criticality Safety Program are documented in LRD-18001, "INL Criticality Safety Program Requirements Manual.” LRD-18001 contains requirements and recommendations that are in compliance with 10 CFR 830.204, DOE Orders, mainly DOE Order 420.1B, Chapter III. "Nuclear Criticality Safety," DOE Standards, industry standards, and best management practices used at the INL and throughout the DOE complex. The source requirement documents are listed in the "Requirements Management" section. Following each requirement and recommendation in LRD-18001 is a reference in parentheses listing the source document(s) or BMP for Best Management Practice. A unique document was created that demonstrates complete requirements roll-down for all source requirements. This document, NS-18210, "Criticality Safety Program Requirements Identification and Implementation Document," has a matrix for each source requirement and a reference to where in the program the requirement is implemented. NS-18210 effectively demonstrates that the program is in compliance with all source requirements.

The majority of criticality safety source requirements are contained in DOE Order 420.1B because it invokes all of the ANSI/ANS 8-Series Standards. In addition to ANSI/ANS Standards, DOE Order 420.1B also invokes several DOE Standards, including DOE-STD-3007, "Guidelines for Preparing Criticality Safety Evaluations at Department of Energy Non-Reactor Nuclear Facilities."

DOE Order 420.1B also contains requirements for DOE "Heads of Field Elements" to approve the criticality safety program and specific elements of the program, namely, the qualification of criticality staff and the method for preparing criticality safety evaluations. This was accomplished by the approval of SAR-400, "INL Standardized Nuclear Safety Basis Manual," Chapter 6, "Prevention of Inadvertent Criticality," which was first submitted to DOE-ID in June, 2006. Chapter 6 of SAR-400 contains sufficient detail and/or reference to the specific DOE and contractor documents that adequately describe the INL Criticality Safety Program per the elements specified in DOE Order 420.1B. The DOE Safety Evaluation Report for SAR-400 states that the approval of SAR-400 approves the INL Criticality Safety Program. This demonstrates clear DOE approval of the INL Criticality Safety Program.

A new software quality assurance and configuration management plan was issued in 2010 . This document meets DOE and Laboratory quality assurance requirements. Verification and validation documentation was completed for the most recent versions of MCNP and SCALE in 2011. This effort also addressed new hardware and software.

A complete list of all INL Criticality Safety Program documents is contained in NS-18209, "List of Criticality Safety Program Documents," and is included in the Appendix. 
IAS 1236

INL/EXT-11-23919

Page 12 of 16

Several criticality safety program documents were improved in 2011 . The program documents revised in 2011 include:

- NS-18202, "Criticality Safety Assessments"

- NS-18209, "List of Criticality Safety Program Documents"

- INL/INT-10-19661, "MCNP5 1.51 Verification and Validation for the Criticality Safety Analysis Software Application

- INL/INT-11-22236, "SCALE 6.0 Verification and Validation for the Criticality Safety Analysis Software Application 
IAS 1236

INL/EXT-11-23919

Page 13 of 16

\section{Training}

Criticality safety training is a strength of the INL program, but there is always room for improvement. Criticality Safety Engineering review of the facility specific training materials was identified as a previous issue. ICARE item DR 42158 was initiated to address this issue. Reviews of all fissionable material handler training programs at the INL were scheduled. To date, reviews of the Fuel Conditioning Facility, Fuel Manufacturing Facility, Hot Fuel Examination Facility, Nuclear Material Inspection and Storage facility, Radioactive Scrap and Waste Facility, Space and Security Power Systems Facility, Transient Reactor Test Facility, Zero Power Physics Reactor, Advanced Test Reactor and Advanced Test Reactor Critical facility have been completed. The reviews documented criticality scenarios and identified areas for improvement. These reviews strengthened operator understanding of criticality safety for their facilities and minimize violations.

Criticality Safety training has been developed for many employee positions, including fissionable material handlers, facility managers, criticality safety officers, firefighters, and criticality safety engineers.

The training for firefighters was introduced to the INL in 2007. Besides responding to fires, firefighters are the first responders to a criticality alarm or accident. The training (0INL1226, "Criticality Safety for Firefighters") is web-based and includes a companion study guide, INL/EXT-07-12074, "Criticality Safety Basics for INL Emergency Responders." The training explains why fire-fighting restrictions may be in place, provides examples of restrictions, and helps first responders learn and recognize the effects of direct neutron/gamma radiation resulting from a criticality accident. Feedback from the firefighters has been very positive. An update to this training module is planned for FY2012 to incorporate comments and improve understanding.

Fissionable Material Handler training continues to improve at the INL. Standardized training on the principles of criticality safety was developed in 2006 (00INL189, "INL Criticality Safety Principles"). This web-based training is much more efficient for most handlers and provides better training than that received previously at some facilities. Since its inception in 2006, hundreds of INL personnel have taken 00INL189. The study guide that accompanies the training, INL/EXT-06-01183, "Criticality Safety Basics for INL FMHs and CSOs," has been well received. Hundreds of copies of the study guide have been given to FMHs by facility management and training personnel. A review of comments from those who have taken the training and test question performance has identified areas for improvement. A major improvement effort was planned for FY2011, but was delayed due to emerging work. Several improvements have been made that better address basic physics, more emphasis on parameter control factors, and more examples for solid systems rather than solutions. The changes are currently being programmed into the training and the revision is expected to be complete in early 2012. Facility specific training on new and existing criticality controls was provided by Criticality Safety Engineering to operators in classroom settings for FCF, FMF, HFEF, TREAT, and ZPPR. 
IAS 1236

INL/EXT-11-23919

Page 14 of 16

Criticality Safety Engineers again provided numerous training sessions for FMHs at MFC. This has been beneficial to both Criticality Safety Engineering and Nuclear Operations. The technicians have learned new concepts, criticality safety engineers have learned more about the facilities, and a positive relationship continues to develop between the organizations.

The criticality safety training for Facility Managers (00INL618, "Criticality Safety Training for Facility Managers") continues to have a positive effect on the Criticality Safety Program. This training focuses on criticality safety roles and responsibilities and has created an ownership role in line management that is the strength of the INL Criticality Safety Program. 00INL618 is a course taught by the Criticality Safety Engineering Department Manager and results in a positive relationship between the organizations. An update of the training was made in 2011.

The criticality safety training for Criticality Safety Officers (0INL1134, "INL Criticality Safety Officer Training") has also had a positive impact on the Criticality Safety Program. This training focuses on criticality safety roles and responsibilities for CSOs and creates an ownership role within the facility. OINL1134 is a course taught by the Criticality Safety Engineering Department Manager and results in a positive relationship between the Department and the CSO. Improvements to 0INL1134 were again made in 2011. The CSO qualification standard was revised in 2010 to require an interview of the trainee by the Criticality Safety Engineering Manager. This change was made to strengthen the CSO's knowledge and understanding of facility specific controls and their implementation. The CSOs are an extremely important element of the INL Criticality Safety Program.

Criticality safety engineer training and qualification is documented in NS-18203, "Criticality Safety Engineer Qualification Plan." This qualification was written to, and meets requirements of DOE Order 426.2, DOE-STD-1135, "Guidance for Nuclear Criticality Safety Engineer Training and Qualification," and ANSI/ANS-8.26-2007, "Criticality Safety Engineer Training and Qualification Program." NS-18203 was revised in 2009 to include additional required training courses available in the DOE Complex for engineers to attend. A revision to NS-18203 was planned for 2011 but did not occur. Newly hired criticality safety engineers in the Department are working on their qualification (QNCRITEG). The existing plan assumes a certain level of experience and is not adequate for engineers out of college. The qualification needs to be strengthened to help new engineers realize expectations.

A new training module was developed in 2009 by Criticality Safety Engineering to supplement MFC training for certified fissionable material handlers (operators). The training, "Applied Science of Criticality Safety, " builds upon the existing training and gives the operators a better understanding of criticality accidents and how controls are derived. The training was significantly revised in 2011 to include more accidental criticality information and presented in August of 2011. 
IAS 1236

INL/EXT-11-23919

Page 15 of 16

A new training course was developed for the Nuclear Infrastructure Assessment and Disablement Team (NIAD). The course was coordinated with National Nuclear Safety Administration (NNSA) and included the following topics: 1) Principles of Criticality Safety, 2) Criticality Accidents, 3) Criticality safety limits and their use, and 4) Applications. The training was well received by the customer, the U.S. Army. This training module was revised in 2011 to incorporate recovery actions from accidental criticalities and taught to the NIAD in April of 2011. 
IAS 1236

INL/EXT-11-23919

Page 16 of 16

\section{Programmatic Support}

The major deliverable of the INL Criticality Safety Engineering Department is performing criticality safety evaluations (CSEs) that support work. There is little need for a criticality safety organization if there isn't a need to handle and store fissionable material. CSEs derive administrative and engineered criticality controls and limits. The CSEs support changes to Documented Safety Analyses (DSAs) and Criticality Control Lists (LST) that document the facility specific controls.

Seventeen CSEs (includes revisions to existing CSEs) were completed in support of ATR Complex, MFC and CPP-651 operations. Other reports were issued for training and software qualification and verification. In addition to these technical reports, all DSA revisions and upgrades (TREAT and ZPPR) were reviewed by criticality safety personnel to ensure that CSEs were used correctly. Fifteen CHCS and LST revisions were written and approved in 2011 to support new work at MFC (including Inter-facility Transfers, FCF, FMF, HFEF, TREAT, and ZPPR facilities). Many of the revisions involved follow up training of operators by criticality safety engineers.

No new CCAs were created in 20011, but seven new Criticality Safety Officers were appointed, trained, and qualified. There are currently 26 CCAs that are located at ATR Complex, MFC, PBF and REC.

All of the work was planned and scheduled. A list of documents issued by the Criticality Safety Engineering Department is included in the "Programmatic Support" section. The Criticality Safety Engineering Department hired two recent graduates in 2010 and used two subcontractors to augment staff in 2011. The contractors completed their assignments in early 2011, and have taken employment elsewhere. One of those engineers left the INL in 2011. The existing staffing level is projected to be adequate for the projected 2012 workload.

A significant upgrade was completed for the Criticality Safety Computational Network. A new network storage device and uninterruptible power supplies were installed. This equipment greatly reduced the effort to manage the system. In addition, a new more powerful workstation with multiple processors was procured and installed. This system was needed to support the computational intensive criticality alarm detector and accident evaluations for ZPPR and CPP-651. The latest versions of SCALE and MCNP were installed and verified for the network. The latest version of SCALE was used for burnup calculations in support of the EBR-II fuel returns from INTEC.

The INL Criticality Safety Engineering Department met all commitments and supported all Laboratory milestones. 2011 was a very successful year. 
Appendix 


\section{Integrated Assessment Schedule for Criticality Safety 2011}




\section{Current Assessment Schedule}

\begin{tabular}{|c|c|c|c|c|c|}
\hline \multirow[t]{5}{*}{ AS ID } & \multicolumn{5}{|c|}{ IAS11714 - Protection of Controlled Unclassified Information } \\
\hline & \multirow{2}{*}{\begin{tabular}{|l|} 
Risk Level: \\
Low \\
$\begin{array}{l}\text { Assessment Lead: } \\
\text { Taylor, Joseph Todd }\end{array}$ \\
\end{tabular}} & \multicolumn{2}{|l|}{ Risk Description: } & \multirow{2}{*}{\multicolumn{2}{|c|}{$\begin{array}{l}\text { Performing Organization: } \\
\text { W310 - CRITICALITY } \\
\text { SAFETY ENGINEERING } \\
\begin{array}{l}\text { Assessment Type: } \\
\text { Inspection }\end{array} \\
\end{array}$}} \\
\hline & & \multirow{2}{*}{$\begin{array}{l}\text { Resp Mgr: } \\
\text { Taylor, Joseph Todd } \\
\text { Scheduled End: } \\
09 / 30 / 2011\end{array}$} & \multirow{2}{*}{\begin{tabular}{|l} 
AC: \\
French, Mary Ellen \\
Report Date: \\
09/21/2011
\end{tabular}} & & \\
\hline & $\begin{array}{l}\text { Scheduled Start: } \\
10 / 07 / 2010\end{array}$ & & & $\begin{array}{l}\text { Status: } \\
\text { Closed }\end{array}$ & Rqrd: \\
\hline & $\begin{array}{l}\text { Facility: } \\
\text { REC/WCB }\end{array}$ & \multicolumn{2}{|c|}{$\begin{array}{l}\text { Assessed Organization: } \\
\text { W300 - Nuclear Safety Engineering }\end{array}$} & \multicolumn{2}{|c|}{$\begin{array}{l}\text { Work Evolution } \\
\text { Observation: } \\
\text { No }\end{array}$} \\
\hline \multirow[t]{5}{*}{ AS ID } & \multicolumn{5}{|c|}{ IAS11702 - Criticality Control Area (CCA) Inspections } \\
\hline & $\begin{array}{l}\text { Risk Level: } \\
\text { Low }\end{array}$ & \multicolumn{2}{|l|}{ Risk Description: } & \multicolumn{2}{|c|}{$\begin{array}{l}\text { Performing Organization: } \\
\text { W310 - CRITICALITY } \\
\text { SAFETY ENGINEERING }\end{array}$} \\
\hline & $\begin{array}{l}\text { Assessment Lead: } \\
\text { Taylor, Joseph Todd }\end{array}$ & $\begin{array}{l}\text { Resp Mgr: } \\
\text { Taylor, Joseph Todd }\end{array}$ & $\begin{array}{l}\text { AC: } \\
\text { French, Mary Ellen }\end{array}$ & \multicolumn{2}{|c|}{$\begin{array}{l}\text { Assessment Type: } \\
\text { Inspection, Surveillance }\end{array}$} \\
\hline & $\begin{array}{l}\text { Scheduled Start: } \\
10 / 11 / 2010\end{array}$ & $\begin{array}{l}\text { Scheduled End: } \\
09 / 30 / 2011\end{array}$ & \begin{tabular}{|} 
Report Date: \\
09/29/2011
\end{tabular} & $\begin{array}{l}\text { Status: } \\
\text { Completed }\end{array}$ & Rqrd: \\
\hline & $\begin{array}{l}\text { Facility: } \\
\text { REC Labs } \\
\text { MFC } \\
\text { ATR Complex }\end{array}$ & \multicolumn{2}{|c|}{$\begin{array}{l}\text { Assessed Organization: } \\
\text { C000 - Nuclear Science \& Technology } \\
\text { GC00 - MFC Nuclear Operations } \\
\text { D000 - National \& Homeland Security } \\
\text { GB00 - ATR Programs }\end{array}$} & \multicolumn{2}{|c|}{$\begin{array}{l}\text { Work Evolution } \\
\text { Observation: } \\
\text { No }\end{array}$} \\
\hline \multirow[t]{5}{*}{ AS ID } & \multicolumn{5}{|c|}{ IAS11711 - Criticality Safety Program Effectiveness Review } \\
\hline & $\begin{array}{l}\text { Risk Level: } \\
\text { Moderate }\end{array}$ & \multicolumn{2}{|l|}{ Risk Description: } & \multicolumn{2}{|c|}{$\begin{array}{l}\text { Performing Organization: } \\
\text { W310 - CRITICALITY } \\
\text { SAFETY ENGINEERING }\end{array}$} \\
\hline & $\begin{array}{l}\text { Assessment Lead: } \\
\text { Taylor, Joseph Todd }\end{array}$ & $\begin{array}{l}\text { Resp Mgr: } \\
\text { Taylor, Joseph Todd }\end{array}$ & $\begin{array}{l}\text { AC: } \\
\text { French, Mary Ellen }\end{array}$ & \multicolumn{2}{|c|}{$\begin{array}{l}\text { Assessment Type: } \\
\text { Independent }\end{array}$} \\
\hline & $\begin{array}{l}\text { Scheduled Start: } \\
10 / 18 / 2010\end{array}$ & $\begin{array}{l}\text { Scheduled End: } \\
12 / 15 / 2011\end{array}$ & Report Date: & $\begin{array}{l}\text { Status: } \\
\text { Planned }\end{array}$ & $\underset{Y}{\text { Rqrd: }}$ \\
\hline & $\begin{array}{l}\text { Facility: } \\
\text { MFC } \\
\text { MFC/SSPSF }\end{array}$ & \multicolumn{2}{|c|}{$\begin{array}{l}\text { Assessed Organization: } \\
\text { GC00 - MFC Nuclear Operations }\end{array}$} & \multicolumn{2}{|c|}{$\begin{array}{l}\text { Work Evolution } \\
\text { Observation: } \\
\text { No }\end{array}$} \\
\hline
\end{tabular}




\begin{tabular}{|c|c|c|c|c|c|}
\hline \multirow[t]{3}{*}{ AS ID } & \multicolumn{5}{|c|}{ IAS111705 - Assessment of Criticality Safety SQA } \\
\hline & \multirow{2}{*}{\begin{tabular}{|l|}
$\begin{array}{l}\text { Risk Level: } \\
\text { Moderate }\end{array}$ \\
$\begin{array}{c}\text { Assessment Lead: } \\
\text { Taylor, Joseph Todd }\end{array}$ \\
\end{tabular}} & \multicolumn{2}{|l|}{ Risk Description: } & \multirow{2}{*}{\multicolumn{2}{|c|}{\begin{tabular}{|l} 
Performing Organization: \\
W310 - CRITICALITY \\
SAFETY ENGINEERING \\
$\begin{array}{c}\text { Assessment Type: } \\
\text { Inspection }\end{array}$ \\
\end{tabular}}} \\
\hline & & \multirow{2}{*}{\begin{tabular}{|l|} 
Resp Mgr: \\
Taylor, Joseph Todd \\
Scheduled End: \\
09/30/2011
\end{tabular}} & \multirow{2}{*}{$\begin{array}{l}\text { AC: } \\
\text { French, Mary Ellen } \\
\text { Report Date: } \\
\text { 09/29/2011 }\end{array}$} & & \\
\hline & $\begin{array}{l}\text { Scheduled Start: } \\
08 / 26 / 2011\end{array}$ & & & $\begin{array}{l}\text { Status: } \\
\text { Closed }\end{array}$ & Rqrd: \\
\hline & $\begin{array}{l}\text { Facility: } \\
\text { REC Other }\end{array}$ & \multicolumn{2}{|c|}{$\begin{array}{l}\text { Assessed Organization: } \\
\text { W300 - Nuclear Safety Engineering }\end{array}$} & \multicolumn{2}{|c|}{$\begin{array}{l}\text { Work Evolution } \\
\text { Observation: } \\
\text { No }\end{array}$} \\
\hline \multirow[t]{5}{*}{ AS ID } & \multicolumn{5}{|c|}{ IAS1236 - Criticality Safety Program Performance Review (CDRL) } \\
\hline & $\begin{array}{l}\text { Risk Level: } \\
\text { Low }\end{array}$ & \multicolumn{2}{|l|}{ Risk Description: } & \multicolumn{2}{|c|}{$\begin{array}{l}\text { Performing Organization: } \\
\text { W310 - CRITICALITY } \\
\text { SAFETY ENGINEERING }\end{array}$} \\
\hline & $\begin{array}{l}\text { Assessment Lead: } \\
\text { Taylor, Joseph Todd }\end{array}$ & $\begin{array}{l}\text { Resp Mgr: } \\
\text { Taylor, Joseph Todd }\end{array}$ & $\begin{array}{l}\text { AC: } \\
\text { French, Mary Ellen }\end{array}$ & \multicolumn{2}{|c|}{$\begin{array}{l}\text { Assessment Type: } \\
\text { Management }\end{array}$} \\
\hline & $\begin{array}{l}\text { Scheduled Start: } \\
10 / 03 / 2011\end{array}$ & $\begin{array}{l}\text { Scheduled End: } \\
12 / 23 / 2011\end{array}$ & Report Date: & $\begin{array}{l}\text { Status: } \\
\text { Planned }\end{array}$ & Rqrd: \\
\hline & $\begin{array}{l}\text { Facility: } \\
\text { Lab-wide }\end{array}$ & \multicolumn{2}{|c|}{$\begin{array}{l}\text { Assessed Organization: } \\
\text { G600 - Nuclear Safety Engineering } \\
\text { W300 - Nuclear Safety Engineering }\end{array}$} & \multicolumn{2}{|c|}{$\begin{array}{l}\text { Work Evolution } \\
\text { Observation: } \\
\text { No }\end{array}$} \\
\hline
\end{tabular}

$5 \operatorname{record}(s)$. 


\section{IAS11702 \\ "Criticality Control Area Inspections"}




\section{INTEROFFICE MEMORANDUM Idaho Naional lobocitory}

Date: $\quad$ October 3,2011

$\begin{array}{llcc}\text { To: } & \text { J. T. Taylor } & \text { MS 3458 } & 6-9656 \\ \text { From: } & \text { A. B. Hoffman } & \text { MS 3458 } & 6-1252 \\ \text { Subject: } & \text { Completion of 2011 CCA Inspections - Closeout IAS11702-ABH-01-2011 } & \end{array}$

Criticality Control Areas (CCAs) at the INL (see the CCA Master List in the Attachment) have been inspected by Criticality Safety Engineering per LWP-18003, "Establishing, Operating, and Deleting Criticality Control Areas (CCAs)" and NS-18202, "Criticality Safety Assessments", These annual reviews are to ensure that process conditions have not been altered to affect the criticality safety evaluations. No conditions were identified that would invalidate a criticality safety evaluation.

Currently there are a total of 26 CCAs at MFC, PBF (CITRC), ATR Complex, and STC. These operations or processes involve significant quantities of fissionable material and require criticality controls. The inspections included a facility walk down and interviews with personnel, usually the Criticality Safety Officers (CSOs), per the requirements of LWP-18003. Inspections were documented on Form 431.03, "Criticality Control Area (CCA) Inspection Checklist", per NS-18202. The checklists used in the inspections are maintained in the Criticality Safety Group per NS-18305, "Records Management Plan for Nuclear Safety Engineering" and copies have been forwarded to the CSOs and their respective facility managers or laboratory managers. A summary listing of the checklists is included in the Attachment. Improvements and recommendations identified by the inspections were screened using LWP-13840, "Management of Issues, Observations, and Noteworthy Practices".

Items corrected immediately included suggested CCA Master List improvements such as updating control list documents, updating names of CSOs and alternates, and CCA Line Managers. Recommendations made by Criticality Safety Engineering included the following:

An inspection at HFEF (CSI11102) determined that a Mass limit CCA, located in room 125 within the HFEF Procedure CCA be eliminated since the majority of the material has been transferred to another CCA at MFC. This required a revision to the HFEF CHCS document, HFEF-OI-1020, which has been submitted to HFEF for review. Most of the material in room 125 was transferred into the Flectron Microscopy Lab (EML) CCA at MFC/ANLW-774.

Criticality Safety Engineering made a recommendation at CITRC CCAs (CSI11105) that the Laboratory Instruction (LI) for work in this CCA be revised to reflect moderated fissionable equivalent (MFE), which was implemented in several INL facilities in 2010. Homeland Security has a project planned, contingent on funding, to conduct detection of fissionable material (DTRA-LEU) using activeinterrogation at the SOX range. This material would have little effect on the current inventory. Criticality Safety has requested to review and approve the LI before the exercise is approved for funding.

During a CCA inspection at ATRC (CS111101), Criticality Safety Engineering observed CSOs transfer material to authorized UN Type A 7A drums in preparation of receiving the AFIP-7 experiment. 


\section{J. T. Taylor}

Attachment

ABH-01-11

Page 2

Material handling and calculation of CSIs were observed and were in compliance with ATRC criticality safety limits.

At FMF, an inspection (CSI11117) identified the need to address the "no liquid" control for approved storage as well as the need for identification of special reflectors in the next LST-386 revision. This has been documented in ICAMS per LWP-13840, "Management of Issues, Observations, and Noteworthy Practices".

In addition to the CCA inspections, per NS-18202, "Criticality Safety Assessments", section 4.2.2, an annual review was completed of information from Safeguards and Security of all Material Balance Areas (MBAs) at INL facilities that contain 15 grams or greater of fissionable material. The MBA information provided a list of fissionable material, custodians, facility, building and location for the following areas: ATR Complex (includes CFA, IF town facilities and CITRC), MFC and PBF. As a result of this review, all MBAs were reviewed. An MBA at CFA-625 containing radioactive sources stored in a cargo container that is used for research experiments was re-evaluated. The material inventory was previously evaluated in 2008 (JTT-11-08) and was determined that a CCA is not necessary per LRD-18001 and LWP-18003 requirements.

Criticality Safety Engineering has concluded that all areas with an inventory of 15 grams or greater have been evaluated for designation as Criticality Control Areas (CCA) per LWP-18003 "Establishing, Operating, and Deleting Criticality Control Areas (CCAs)" and no conditions exist that invalidate the existing criticality safety evaluations.

It should be noted that the specific MBA information is Official Use Only and is not included in this correspondence. If you have any questions regarding this effort, please call J. T. Taylor (6-9656) or A. B. Hoffman

$(6-1252)$.

\section{Attachment}

Uniform File Code: $\underline{7651}$

Disposition Authority: ENV1-b-4-a

Retention Schedule: Review annually. Cutoff when superseded, obsolete or cancelled. Destroy 75 years after cutoff.

NOTE: Original disposition authority, retention schedule, and Uniform Filing Code applied by the sender may not be appropriate for all recipients. Make adjustments as needed. 
J. T. Taylor

Attachment

ABH-01-11

Page 1

\begin{tabular}{|c|c|c|c|c|c|c|c|c|c|c|}
\hline Building No. & $\begin{array}{l}\text { Area } \\
\text { Description } \\
\text { (CCA Name) }\end{array}$ & Line Manager & $\begin{array}{l}\text { CCA } \\
\text { Type } \\
\text { M/P }\end{array}$ & $\begin{array}{l}\text { Critcality Safety } \\
\text { Officer (CSO) }\end{array}$ & $\begin{array}{l}\text { Control } \\
\text { Identification } \\
\text { Document }\end{array}$ & $\begin{array}{l}\text { CAS } \\
\text { Y/N }\end{array}$ & $\begin{array}{l}\text { List \# } \\
\text { After } \\
\text { SAR } \\
\text { Upgr } \\
\text { ade }\end{array}$ & $\begin{array}{l}\text { LRD- } \\
18001 \\
\text { Implemen } \\
\text { tation } \\
\text { Documen } \\
t\end{array}$ & $\begin{array}{l}\text { OI/TPR Proc. } \\
\#\end{array}$ & $\begin{array}{l}\text { CCA } \\
\text { Inspection }\end{array}$ \\
\hline MFC/ANLW-704 & FMF & J. E. Mayer (3-7999) & $P$ & C. S. Brower (3-7044) & LST-386 & Yes & NA & IAS07196 & FMF-OI-005 & CSI11117 \\
\hline MFC/ANLW-720 & TREAT & $\begin{array}{l}\text { S. S. Cunningham } \\
(3-7969)\end{array}$ & $P$ & K. L. Brinker (3-7287) & TREAT-OI-1014 & Yes & $\begin{array}{l}\text { LST. } \\
387\end{array}$ & TBD & $\begin{array}{l}\text { TREAT-OI- } \\
1015\end{array}$ & CSI11116 \\
\hline MFC/ANLW-723 & TREAT-WH & P. J. Crane (3-7179) & $P$ & J. L. Shriver (3-8012) & TREAT-OH-1017 & No & $\begin{array}{l}\text { SAR- } \\
410\end{array}$ & TBD & $\begin{array}{l}\text { TREAT-OI- } \\
\text { 1021, TREAT- } \\
\text { O1-2360 }\end{array}$ & CSI111115 \\
\hline MFC/ANLW-752 & $\begin{array}{l}\text { Analytical } \\
\text { Laboratories }\end{array}$ & T. C. Couch (3-7944) & $P$ & G. I. Dexter (3-8029) & INLINT-08-14953 & No & $\begin{array}{l}\text { LST: } \\
389\end{array}$ & TBD & $\begin{array}{l}\text { AL-6000-OI- } \\
001\end{array}$ & CSI11114 \\
\hline MFC/ANLW-765 & FCF & P. J. Crane (3-7179) & $P$ & J. L. Shriver (3-8012) & F0000-0026-ES & Yes & $\begin{array}{l}\text { LST- } \\
390\end{array}$ & TBD & FCF-OI-1302 & CSI11113 \\
\hline MFC/ANLW-771 & RSWF & P. J. Crane (3-7179) & $P$ & $\begin{array}{l}\text { J. Blankenship (3- } \\
\text { 7059) }\end{array}$ & LST-391 & No & NA & IAS0888 & $\begin{array}{l}\text { RSWF-OI-001, } \\
\text { Storage } \\
\text { Operations, } \\
\text { RSWF-Ol-003, } \\
\text { Material } \\
\text { Acceptance }\end{array}$ & CSI11112 \\
\hline MFC/ANLW-772 & $\begin{array}{l}\text { Radiography } \\
\text { Lab Rm } 103 \\
\text { (EDL) }\end{array}$ & S. L. Winn (3-7814) & M & J. J. Green (3-8092) & LWP-18003 & No & NA & NA & NA & CSI11111 \\
\hline MFC/ANL-W-774 & $\begin{array}{l}\text { Electron } \\
\text { Microscopy Lab } \\
\text { (EML) }\end{array}$ & L. T. Evens $(3-8036)$ & $\mathrm{P}$ & $\begin{array}{l}\text { J. C. Merrill (3-7809) } \\
\text { M. A. Osment (3- } \\
7424 \text { ) }\end{array}$ & INLINT-10-18996 & No & NA & NA & SD-37.1.4 & CSI11121 \\
\hline $\begin{array}{l}\text { MFC/ANLW- } \\
775 / 776\end{array}$ & $\begin{array}{l}\text { ZPPR Work } \\
\text { Room Vault, } \\
\text { and Cell }\end{array}$ & J. E. Mayer (3-7999) & $\mathrm{P}$ & C. S. Brower (3-7044) & W0430-0006-KH & Yes & $\begin{array}{l}\text { LST- } \\
392\end{array}$ & TBD & ZPPR-OI-005 & CSI11110 \\
\hline MFC/ANLW-785 & HFEF & R. L. Casler (3-7621) & $\mathrm{P}$ & K. L. Kynaston $(3-7680)$ & HFEF-OI-1020 & No & $\begin{array}{l}\text { LST- } \\
393\end{array}$ & TBD & HFEF-Ol-1302 & CSI11109 \\
\hline MFC/ANLW-785 & $\begin{array}{l}\text { HFEF Room } \\
125 \text { (incl } 127 \\
\text { and 129) }\end{array}$ & R. L. Casler (3-7621) & M & K. L. Kynaston $(3-7680)$ & LWP-18003 & No & NA & NA & LWP-18003 & CS111102 \\
\hline MFC/ANLW-787 & FASB & L. T. Evens & P & J. J. Green (3-8092) & INLINT-10-18996 & No & NA & $T B D$ & SD-37.1.4 & CSI11107 \\
\hline MFC/ANLW-792A & SSPSF & $\begin{array}{l}\text { R. A. Gunderson (3- } \\
8045 \text { ) }\end{array}$ & $\mathrm{P}$ & $\begin{array}{l}\text { R. P Gomez (3- } \\
8088)\end{array}$ & LST-395 & No & NA & TBD & $\begin{array}{l}\text { SSPSF-O1- } \\
21160\end{array}$ & CSI11106 \\
\hline
\end{tabular}


J, T, Taylor Attachment ABH-01-11 Page 2

\begin{tabular}{|c|c|c|c|c|c|c|c|c|c|c|}
\hline Building No. & $\begin{array}{l}\text { Area } \\
\text { Description } \\
\text { (CCA Name) }\end{array}$ & Line Manager & $\begin{array}{l}\text { CCA } \\
\text { Type } \\
\text { M/P }\end{array}$ & $\begin{array}{l}\text { Critcality Safety } \\
\text { Officer (CSO) }\end{array}$ & $\begin{array}{l}\text { Control } \\
\text { Identification } \\
\text { Document }\end{array}$ & $\begin{array}{l}\text { CAS } \\
\text { Y/N }\end{array}$ & $\begin{array}{l}\text { List \# } \\
\text { After } \\
\text { SAR } \\
\text { Upgr } \\
\text { ade }\end{array}$ & $\begin{array}{l}\text { LRD- } \\
18001 \\
\text { Implemen } \\
\text { tation } \\
\text { Documen } \\
\mathrm{t}\end{array}$ & $\begin{array}{l}\text { OIITPR Proc. } \\
\#\end{array}$ & $\begin{array}{l}\text { CCA } \\
\text { Inspection }\end{array}$ \\
\hline MFC/ANLW-797 & ORSA & P. I Crane (3-7179) & $P$ & $\begin{array}{l}\text { J. Blankenship (3- } \\
7059)\end{array}$ & INLINT-09-15995 & No & NA & NA & TSD-0i-004 & CSI11122 \\
\hline MFC/ANLW-794 & CESB & L. T. Evens $(3-8036)$ & $P$ & J. J. Green (3-8092) & INLINT-09-15995 & No & NA & NA & $\begin{array}{l}\text { CESB-OI-001, } \\
\text { TSD-01-004 }\end{array}$ & CSI11123 \\
\hline MFC/ANL-W-1702 & $\begin{array}{l}\text { Radioctiemistry } \\
\text { Lab (RCL) }\end{array}$ & L. T. Evens $(3-8036)$ & M & $\begin{array}{l}\text { J. C. Merrill (3-7809) } \\
\text { J. J. Green (3-8092) }\end{array}$ & LWP-18003 & No & NA & NA & SD-37.1.4 & CSI11124 \\
\hline IRC/IF-638 & Lab Room 115 & L. D. Smith* (6-1182) & M & $\begin{array}{l}\text { S. C. Taylor (6-6125) } \\
\text { G. L. Seal (6-7838) } \\
\text { (alt) }\end{array}$ & LWP-18003 & No & NA & NA & $\begin{array}{l}\text { LWP-18003, LI } \\
\text { 1139-07-STC }\end{array}$ & CSI11118 \\
\hline IRC/IF-603 & Lab C-6 & L. D. Smith* (6-1182) & M & $\begin{array}{l}\text { S. C. Taylor (6-6125) } \\
\text { G. L. Seal (6-7838) } \\
\text { (alt) }\end{array}$ & LWP-18003 & No & NA & NA & $\begin{array}{l}\text { LWP-18003, LI } \\
\text { 1138-07-IRC }\end{array}$ & CSI11119 \\
\hline PBF/PER-612 & CITRC & D. G. Blatter (6-5100) & P & $\begin{array}{l}\text { D. R. Norman (6- } \\
3953)\end{array}$ & JTT-05-09 & No & NA & TBD & L1-399 & CSI111105 \\
\hline PBFIPER-613 & CITRC & D. G. Blatter $(6-5100)$ & $P$ & $\begin{array}{l}\text { D. R. Norman (6- } \\
3953)\end{array}$ & गTा-05-09 & No & NA & NA & LI-399 & CSI11103 \\
\hline PBFIPER-622 & CITRC & D. G. Blatter (6-5100) & $P$ & $\begin{array}{l}\text { J. O. Thaigott (3- } \\
\text { 7624) } \\
\text { J, A. Turnage (3- } \\
7716 \text { ) (alt.) }\end{array}$ & JTT-05-09 & No & NA & NA & LL -399 & CS 111120 \\
\hline RTC/TRA-621 & NMIS & $\begin{array}{l}\text { E J Schuebert (3- } \\
4246 \text { ) }\end{array}$ & $P$ & K. L. Zimmer (3-4063) & $\begin{array}{l}\text { SAR-154-6A, } \\
\text { TSR-154 }\end{array}$ & Yes & NA & TBD & DOP-7.11 & CSI11104 \\
\hline RTC/TRA-670 & $\begin{array}{l}\text { ATR Critical } \\
\text { Facility }\end{array}$ & $\begin{array}{l}\text { E. J. Schuebert (3- } \\
4246 \text { ) }\end{array}$ & $P$ & C. D. Jackson (3-4755) & $\begin{array}{l}\text { SAR-192-10, } \\
\text { TSR-192 }\end{array}$ & No & NA & TBD & $\begin{array}{l}\text { SD-17.3.2, OP- } \\
3.7, \text { OP-3.10 }\end{array}$ & CSI11101 \\
\hline RTC/TRA-670 & ATR Facility & $\begin{array}{l}\text { E. J. Schuebert (3- } \\
4246 \text { ) }\end{array}$ & $P$ & $\begin{array}{l}\text { S. L. Denison (3- } \\
4433 \text { ) }\end{array}$ & $\begin{array}{l}\text { SAR-153-9, TSR- } \\
186\end{array}$ & No & NA & TBD & $\begin{array}{l}\text { TOC } 182,184, \\
185\end{array}$ & CSI111100 \\
\hline
\end{tabular}

\section{As of 10/3//2011}

*Facility Manager for CCA with a Tenant Use Agreement

* Training in progress

Note: Fire fighting restrictions have been removed from this list as none are derived from Criticality Safety requirements. 
Date: September 28,2011

CCA(s) ATR Reactor Area/Canal

CSO: S. L. Denison

(or representative)
Inspector: C. E. Stuart

Building: TRA-670

Organization Name: ATR Operations staff

\section{INSPECTION PURPOSE}

Criticality Safety Engineenng inspections of CCAs are performed to determine compliance with applicable requirements and to ensure that process conditions have not changed that would affect the Criticality Safely Evaluations (CSES).

FACILITY STATUS, SUMMARIZE CHECKLIST ACTIVITIES

Record additional information and comments on page 2. Notify facility management of any imminent safety hazards

N/A YES NO

$\triangle \square 1$. Is CCA information listed correctly on the CCA master list? (Access the master list via https://nucleus . inl. gov/portal/server.pt?open=512\&objlD=369\&mode=2)

Master list date: $\quad 9 / 19 / 2011$

$\triangle \square 2$. Are the boundaries identified and consistent with CCA information on file with Criticality Safety Engineering? Entire Building (with the exception of the ATRC facility) constitutes the ATR CCA.

3. Is the most current and applicable governing criticality safety document in use at the time of this inspection of the CCA? List applicable documents (e g., DSA, CHCS, LST, or CSE).

SAR-153 Section 9.1 \& TSR-186

4. If the CCA is posted, is the CCA posted correctly?

a) Is the CSO identified on posting(s) and, if applicable, Alternate?

b) Correct mass limit identified (applies to Mass CCAs only): $\leq 350 \mathrm{~g} \square$ or $\leq 250 \mathrm{~g}$ limit $\square$

5. How is inventory of fissionable material items maintained? ATR is a Procedure CCA Total $(g):$ N/A

6. If there is a criticality control that affects emergency response, has the CSO reviewed the pre-incident plan? (on file with the INL Fire Department) $\square$ Yes $\square$ No Reference \#

7. Were fissionable materials visibly labeled where practical?

8. Does the CCA have a Criticality Alarm System?

a) Are calibrations and testing current? References:

b) Are detectors free from any obstruction(s) that could impair criticality accident detection?

9. Are activities within facility, equipment, or procedures enveloped by the current and approved criticality safety documents (for example, DSAs, CSEs, applicable approval letter, and/or CHCS/LST of criticality controls) (Notify Facility management immediately if there is a safely concern): (Describe on page 2)

10. Were observed in-progress activities in compliance with criticality safety limits? Describe details on page 2 if applicable. (Notify facility management immediately if there is a safety concern.)

11. Was satisfactory progress made on action items noled during previous inspections? Summarize items and progress on page 2 if applicable.

12. Was the facility free from observable criticality safety problems, other than those described above? Describe items on page 2 if applicable. (Notify facility management immediately if there is a safety concern.) 


\section{ADDITIONAL INFORMATION AND COMMENTS}

All action items from the previous CCA inspection were listed as "suggestions" and did not require corrective action.

Summarize the changes that have been made to the facility, equipment and/or procedures since the last CCA inspection.

No changes that affect criticality safety have been made to the ATR facility since the last CCA inspection.

What are the current activities in the CCA? Describe: (refer to item \#9 from page 1)

The ATR is an operating test reactor with underwater storage racks within the canal. During the CCA inspection, the ATR was in an outage and no fissile material activities were in progress,

$\bigotimes$ None

As documented in ICAMS system per LWP-13840

As documented elsewhere. Reference:

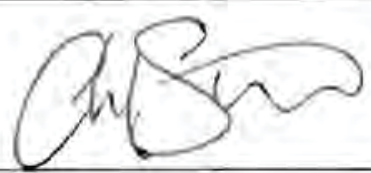


Date: $\quad 22$ March 2011

CCA(s): ATRC

CSO: Craig D. Jackson (or representative) inspector: Valerie L. Putman

Building: TRA-670

Organization Name: ATR/ATRC Operations

\section{INSPECTION PURPOSE}

Criticality Safety Engineering inspections of CCAs are performed to determine compliance with applicable requirements and to ensure that process conditions have not changed that would affect the Criticality Safety Evaluations (CSEs).

FACILITY STATUS, SUMMARIZE CHECKLIST ACTIVITIES

Record additional information and comments on page 2. Notify facility management of any imminent safety hazards

N/A YES NO

$\bigotimes \square$ 1. Is CCA information listed correctly on the CCA master list? (Access the master list via https://nucleus.inl.gov/portal/server.pt?open=512\&objlD=369\&mode=2)

Master list date: $\quad 14$ March 2011

$\triangle \square 2$. Are the boundaries identified and consistent with CCA information on file with Criticality Safety Engineering? Entire ATRC Facility, consistent with description since establishment with CCA approval CCA98021 of 21 September 1998

3. Is the most current and applicable governing criticality safety document in use at the time of this inspection of the CCA? List applicable documents (e.g., DSA, CHCS, LST, or CSE).

SAR-192 Chapter 10 and TSR-J92 AC 5.192.4

$\triangle \square \square$ 4. If the CCA is posted, is the CCA posted correctly? CCA identificalion signs are unnecessary and not posled for ATRC

a) Is the CSO identified on posting(s) and, if applicable, Alternate?

b) Correct mass limit identified (applies to Mass CCAs only): $\leq 350 \mathrm{~g} \square$ or $5250 \mathrm{~g}$ limit $\square$

5. How is inventory of fissionable material iterns maintained? See comment 5 on page 2

Total (g): about $427 \mathrm{~g}$ U-235 in cabinet by 4 p.m. Other stored material not subject to mass limits

$\triangle \square$ 6. If there is a criticality control that affects emergency response, has the CSO reviewed the pre-incident plan? (on file with the INL Fire Department) Reference \#:

7. Were fissionable materials visibly labeled where practical? See comment 7 on page 2

8. Does the CCA have a Criticality Alarm System?

a) Are calibrations and testing current? References:

b) Are detectors free from any obstruction(s) that could impair criticality accident detection?

9. Are activities within facility, equipment, or procedures enveloped by the current and approved criticality safety documents (for example, DSAs, CSEs, applicable approval letter, and/or CHCSILST of criticality controls) (Notify Facility management immediately if there is a safety concern): (Describe on page 2)

References: SAR/TSR-192 for controls: SD-17,3,2, OP-3.7, OP-3,I0 for instructions/documentation

10. Were observed in-progress activities in compliance with criticality safety limits? Describe details on page 2 if applicable. (Nolify facility management immediately if there is a safety concern.)

11. Was satisfactory progress made on action items noted during previous inspections? Summarize items and progress on page 2 if applicable.

12. Was the facility free from observable criticality safety problems, other than those described above? Describe items on page 2 if applicable. (Notify facility management immediately if there is a safety concem.) 
ADDITIONAL INFORMATION AND COMMENTS

1. Suggested CCA Master List Improvement incorporated 23 March 2011: Update the telephone number listed for the CSO, from $3-4756$ to $3-4755$.

5. For information only: The CSO maintains an inventory list and he periodically reconciles the list with LANMAS data using a Safeguards printout of ATRC-specific data. In addition, a reactor status board identifies the locations of each element in the reactor. Another status board is available for tracking out-of-storage fuel when the $365 \mathrm{~g}$ handling limit applies and for tracking the cumulative CSI.

7. For information only: ATR elements and various materials include an engraved identification number. Flux wires are stored in numbered "bottles." ATRC staff members do not need labels that specifically identify fuel items as fissionable, except when required for shipping packages.

10. No fuel was out of storage in the canal during the inspection. Safeguards inventory records indicate the material in the reactor, racks, and cabinet comply with their respective limits (TSR-192 AC 5.192.4). The status board indicates the cumulative CSI is less than 100. See the current activities question below for further information.

Summarize the changes that have been made to the facility, equipment and/or procedures since the last CCA inspection.

Craig D. Jackson was assigned as ATRC CSO on 15 February 2011, replacing Kirk D. Stueve who is still available to assist with ATRC operations. Jackson completed CSO training on 10 March 201 1. Jackson previously qualified as an ATRC Reactor Supervisor, which incorporates FMH Supervisor qualification, on 15 June 2010.

\section{FUTURE CHANGES:}

Criticality Safety Engineering is drafting updates for SAR-192-10 and TSR-192 AC 5.192.4 to incorporate a definition of U-235 equivalence consistent with the definition used at the ATR and NMIS Facilities: " 1 gram of Pu $=1$ gram of U-233 $=2$ grams of U-235." Future drafts will also update criticality accident scenario and contingency scenarios for consistency with the ATR and NMIS Facilities and to simplify the scenario descriptions and criticality safety controls.

New FMH and FMH Supervisor training (part of ATRC Reactor Operator and ATRC Reactor Supervisor training) will also be developed to resolve issues identified in an assessment of ATR and ATRC criticality safety training materials (VLP-04-10). The development may include the above-mentioned safety-basis updates, depending on when those updates will be approved.

What are the current activities in the CCA? Describe: (refer to item \#9 from page 1)

Also see comment 10 above,

This inspection occurred while Craig D. Jackson and Kirk D. Stueve (current and former ATRC CSOs) transferred material from the cabinet to authorized UN Type A 7A drums in accordance with Work Order 152747-01, Prepare for Receipt of AFIP-7. Francisca H. Gutierrez (Safeguards), Stacy W. Meyer (ATR Crafts), Edward G. Waters (Senior Radiological Control Technician), Daniel B. McDonald (shipping engineer), and Susan M. Case (representing Robert Roesener of lrradiation Testing) assisted. Putman observed loading three of the four drums involved. Jackson and Stueve (qualified ATRC FMH Supervisars), performed all fissionable material handling and, working off separate copies of the Work Order, calculated the drum and cumulative CSIs. At the end of the process, ATRC had a cumulative CSI of 28.3 and about $427 \mathrm{~g}^{235} \mathrm{U}$ in the cabinet, in compliance with ATRC criticality safety limits (TSR-192 AC 5.192.4).

\section{ACTION ITEM (Improvements, corrections, etc)}

None

As documented in ICAMS system per LWP-13840

As documented elsewhere. Reference:

\begin{tabular}{|l|l|l}
\hline Report Date & Assessor(s) & Inspection Record No. \\
16 June 2011 & Valerie L, Putman Valorios of Putman
\end{tabular}


Date: June 1, 2011

CCA(s) HFEF Rm 125

CSO: K. L. Kynaston (or representative)
Inspector: C. E. Stuart

Building MFC/ANLW-785

Organization Name: Hot Cell Services

\section{INSPECTION PURPOSE}

Criticality Safety Engineening inspections of CCAs are performed to determine compliance with applicable requirements and to ensure that process conditions have not changed that would affect the Criticality Safety Evaluations (CSEs).

FACILITY STATUS, SUMMARIZE CHECKLIST ACTIVITIES

Record additional informalion and comments on page 2. Nolify facility management of any imminent safety hazards

N/A YES NO

$\bigotimes \square$ 1. Is CCA information listed correctly on the CCA master list? (Access the master list via https://nucleus , inl.gov/portal/server.pt?open=512\&objlD=3698mode=2)

Master list date: $\quad 5 / 02 / 2011$

$\bigotimes \square 2$ Are the boundaries identified and consistent with CCA information on file with Criticality Safety Engineering? Room 125 only

Х $\square$. Is the most current and applicable governing criticality safety document in use at the time of this inspection of the CCA? List applicable documents (e.g., DSA, CHCS, LST, or CSE).

LWP-18003

$\square \square 4$ if the CCA is posted, is the CCA posted correctly?

a) Is the CSO identified on posting(s) and, if applicable, Alternate?

b) Correct mass limit identified (applies to Mass CCAs only): $\leq 350 \mathrm{~g} \square$ or $\leq 250 \mathrm{~g}$ limit $\square$

5. How is inventory of fissionable material items maintained? Total $(\mathrm{g}): 52.0 \mathrm{~g}$ TFM

6. If there is a criticality control that affects emergency response, has the CSO reviewed the pre-incident plan? (on file with the INL Fire Department) $\square$ Yes $\square$ No Reference \#:

7. Were fissionable materials visibly labeled where practical? material was locked within a storage cabinet Does the CCA have a Criticality Alarm System?

a) Are calibrations and testing current? References:

b) Are detectors free from any obstruction(s) that could impair criticality accident detection?

9. Are activities within facility, equipment or procedures enveloped by the current and approved criticality safety documents (for example, DSAs. CSEs, applicable approval letter, and/or CHCS/LST of criticality controls) (Notify Facility management immediately if there is a safety concern): (Describe on page 2)

10. Were observed in-progress activities in compliance with criticality safety limits? Describe details on page 2 if applicable. (Notify facility management immediately if there is a safety concern.)

11. Was satisfactory progress made on action items noted during previous inspections? Summarize items and progress on page 2 if applicable.

$\triangle \square$ 12. Was the facility free from observable criticality safety problems, other than those described above? Describe items on page 2 if applicable. (Notify facility management immediately if there is a safety concern.) 


\section{ADDITIONAL, INFORMATION AND COMMENTS}

1. The current CCA posting lists the previous CSO and alternate, rather than the current CSO (K. L. Kynaston). A new CCA posting sign (Form 431.08 ) has been sent to the CSO in order to post the CCA properly.

2. The listed CSO (K. L. Kynaston) is currently in the process of completing qualification training in order to become certified as a Mass CCA CSO. In order to address this deficiency, Room 125 will be asborbed into the HFEF Procedure CCA and eliminated as an individual Mass CCA. Fissionable material controls for Room 125 will be incorporated into the HFEF CHCS (HFEF-Ol-1020).

3. The current fissionable material inventory is maintained in an Excel Spreadsheet but did not include a total inventory mass. Incorporating Room 125 into the HFEF Procedure CCA (as suggested in item \#2 above) will take care of this concern.

Summarize the changes that have been made to the facility, equipment and/or procedures since the last CCA inspection. The key to the CCA and the inventory was obtained from the former Criticality Safety Officer, Chris McGrath.

What are the current activities in the CCA? Describe: (refer to item \#9 from page 1)

None

$\bigotimes$ As documented in ICAMS system per LWP-13840

As documented elsewhere. Reference:

Report Date Assessor(s)


Date: $\quad$ August 17,2011

CCA(s): CITRC

CSO: D. R. Norman (or representative)
Inspector: J. T. Taylor/A. B. Hoffman

Building: 613

Organization Name: Sensor Technologies

INSPECTION PURPOSE

Criticality Safety Engineering inspections of CCAs are performed to determine compliance with applicable requirements and to ensure that process conditions have not changed that would affect the Criticality Safety Evaluations (CSEs).

FACILITY STATUS, SUMMARIZE CHECKLIST ACTIVITIES

Record additional information and comments on page 2. Notify facility management of any imminent safety hazards

N/A YES NO

$\square$ 1. Is CCA information listed correctly on the CCA master list? (Access the master list via https://nucleus.inl.gov/portal/server,pt?open=512\&objlD=369\&mode=2)

Master list date: $\quad 05 / 02 / 2011$ replaced D. G. Blatter as Line Manager per LWP-18005

2. Are the boundaries identified and consistent with CCA information on file with Criticality Safety Engineering?

$\otimes \square$ 3. Is the most current and applicable governing criticality safety document in use at the time of this inspection of the CCA? List applicable documents (e.g., DSA, CHCS, LST, or CSE).

4. If the CCA is posted, is the CCA posted correctly?

a) Is the CSO identified on posting(s) and, if applicable, Alternate?

b) Correct mass limit identified (applies to Mass CCAs only): $\leq 350 \mathrm{~g} \square$ or $\leq 250 \mathrm{~g}$ limit

5. How is inventory of fissionable material items maintained? see attached inventory form

Total(g): $156.00 \mathrm{~g}$ (PuBe source)

6. If there is a criticality control that affects emergency response, has the CSO reviewed the pre-incident plan? (on file with the INL Fire Departmeni) $\square$ Yes $\square$ No Reference \#:

7. Were fissionable materials visibly labeled where practical?

8. Does the CCA have a Criticality Alarm System?

a) Are calibrations and testing current? References:

b) Are detectors free from any obstruction(s) that could impair criticality accident detection?

9. Are activities within facility, equipment, or procedures enveloped by the current and approved criticality safety documents (for example, DSAS, CSEs, applicable approval letter, and/or CHCS/LST of criticality controls) (Notify Facility management immediately if there is a safety concern) : (Describe on page 2)

10. Were observed in-progress activities in compliance with criticality safety limits? Describe details on page 2 if applicable. (Notify facility management immediately if there is a safety concern.)

\ $\square$ 11. Was satisfactory progress made on action items noted during previous inspections? Summarize items and progress on page 2 if applicable.

$\bigotimes \square$ 12. Was the facility free from observable criticality safety problems, other than those described above? Describe items on page 2 if applicable. (Notify facility management immediately if there is a safety concern.) 
ADDITIONAL INFORMATION AND COMMENTS

PuBe source is contained in a cargo container at Building 613 .

Summarize the changes that have been made to the facility, equipment and/or procedures since the last CCA inspection.

NA

What are the current activities in the CCA? Describe: (refer to item \#9 from page 1)

NA

$\triangle$ None

As documented in ICAMS system per LWP-13840

As documented elsewhere. Reference: 
Idaho National Laboratory

\begin{tabular}{|c|c|c|c|}
\hline $\begin{array}{c}\text { PROCEDURE CRITICALITY CONTROL } \\
\text { AREAS AT CITRC }\end{array}$ & $\begin{array}{l}\text { Identifier: } \\
\text { Revision: } \\
\text { Effective Date: }\end{array}$ & $\begin{array}{l}\text { LI-399 } \\
0 \\
03 / 19 / 09\end{array}$ & Page: 7 of 11 \\
\hline
\end{tabular}

\section{Appendix A - CITRC Criticality Control Areas Inventory Record}

Criticality Safety Officer Signature:
Transfer Verification Signature:

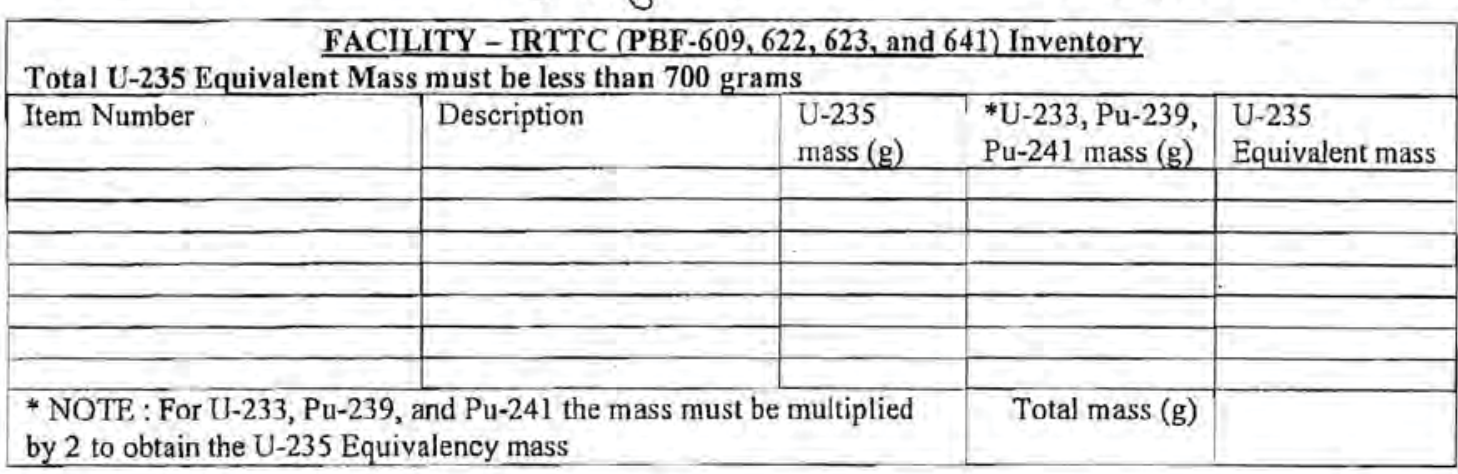

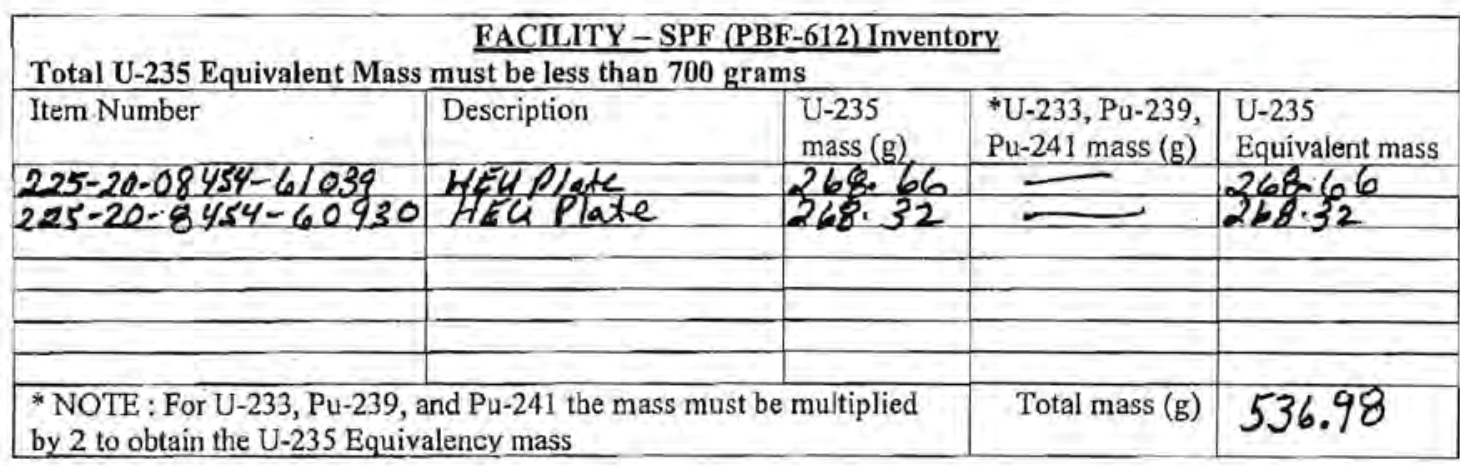

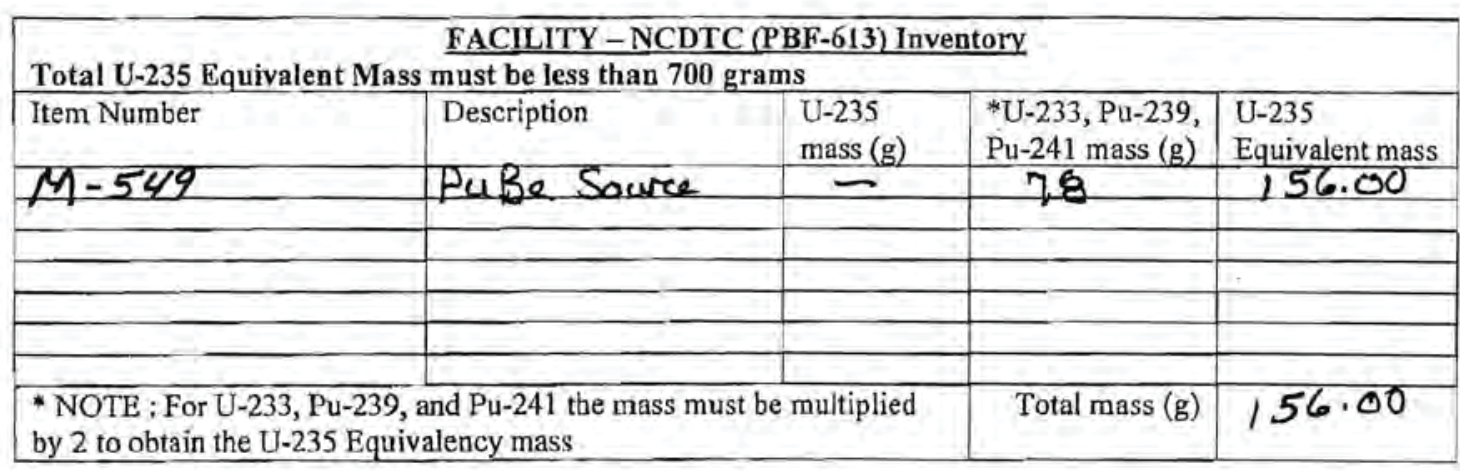

\begin{tabular}{|c|c|c|c|c|}
\hline Total U-235 Equivalent Mas & $\frac{\text { Transfer Ir }}{\text { must be less than } 350 \text { gr }}$ & entory & & \\
\hline Item Number & From ${ }^{2}$ Transfer & \begin{tabular}{|l|}
$\mathrm{U}-235$ \\
mass $(\mathrm{g})$
\end{tabular} & $\begin{array}{l}\text { *U-233, Pu-239, } \\
\text { Pu-241 mass (g) }\end{array}$ & $\begin{array}{l}\text { U-235 } \\
\text { Equivalent mass }\end{array}$ \\
\hline $\begin{array}{l}\text { * NOTE : For U-233, Pu-239, } \\
\text { by } 2 \text { to obtain the U-235 Equi }\end{array}$ & $\begin{array}{l}\text { ind } P u-241 \text { the mass must } \\
\text { alency mass }\end{array}$ & multiplied & Total mass $(\mathrm{g})$ & \\
\hline
\end{tabular}


Date: September 13,2011

CCA(s): NMIS Facility

CSO: K. L. Zimmer (or representative)
Inspector: C. E. Stuart

Building: TRA- 621

Organization Name: ATR/ATRC Operations

\section{INSPECTION PURPOSE}

Criticality Safety Engineering inspections of CCAs are performed to determine compliance with applicable requirements and to ensure that process conditions have not changed that would affect the Cnticality Safety Evaluations (CSES).

\section{FACILITY STATUS, SUMMARIZE CHECKLIST ACTIVITIES}

Record additional information and comments on page 2. Notify facility management of any imminent safety hazards

N/A YES NO

$\triangle \square$ 1. Is CCA information listed correctly on the CCA master list? (Access the master list via https://nucleus.jnl. gov/portal/server.pt?open=512\&objlD=369\&mode=2)

Master list date: $\quad$ 9/19/2011

$\triangle \square$ 2. Are the boundaries identified and consistent with CCA information on file with Criticality Safety Engineering? Entire Building TRA-621 constitutes the NMIS CCA.

$\square \square$ 3. Is the most current and applicable governing criticality safety document in use at the time of this inspection of the CCA? List applicable documents (e.g., DSA, CHCS, LST, or CSE).

SAR-154-6A \& TSR-154

Х $\square$ 4. If the CCA is posted, is the CCA posted correctly?

a) Is the CSO identified on posting(s) and, if applicable, Alternate?

b) Correct mass limit identified (applies to Mass CCAs only) $\leq 350 \mathrm{~g} \square$ or $\leq 250 \mathrm{~g}$ limit $\square$

How is inventory of fissionable material items maintained? NMIS is a Procedure CCA Total $(g):$ N/A

6. If there is a criticality control that affects emergency response, has the CSO reviewed the pre-incident plan? (on file with the INL Fire Department) $\square$ Yes $\quad \square$ No $\quad$ Reference \#: NMIS pre-incident plan. Sept. 2007

7. Were fissionable materials visibly labeled where practical? CSIs appropriately labeled on packages

8. Does the CCA have a Criticality Alarm System?

a) Are calibrations and testing current? References:

b) Are delectors free from any obstruction(s) that could impair criticality accident detection?

9. Are activilies within facility, equipment, or procedures enveloped by the current and approved criticality safety documents (for example, DSAs, CSES, applicable approval letter, and/or CHCS/LST of criticality controls) (Notify Facility management immediately if there is a safety concern): (Describe on page 2)

Х $\square$ 10. Were observed in-progress activities in compliance with criticality safety limits? Describe details on page 2 if applicable. (Notify facility management immediately if there is a safety concern.)

11. Was satisfactory progress made on action items noled during previous inspections? Summarize items and progress on page 2 if applicable.

12. Was the facility free from observable crificality safely problems, other than those described above? Describe items on page 2 if applicable. (Notify facility management immediately if there is a safety concern.) 
All action items from the previous CCA inspection were listed as "suggestions" and did not require corrective action.

Summarize the changes that have been made to the facility, equipment and/or procedures since the last CCA inspection.

Since the last CCA inspection, the most current annual update to the NMIS safety basis (SAR-154, TSR-154) eliminated the requirement for the criticality alarm system (CAS) within the facility. With that change, periodic lesting and calibration requirements for the CAS are no longer necessary.

What are the current activities in the CCA? Describe: (refer to item \#9 from page 1)

NMIS is predominately a storage facility for ATR fuel elements in support of the ATR. No activities were in progress within NMIS during the CCA inspection.

$\bigotimes$ None

As documented in ICAMS system per LWP 13840

As documented elsewhere. Reference:

\begin{tabular}{|l|l|l|l}
\hline Report Date & Assessor(s) & Inspection Record No. \\
September 29,2011 & C.E. Stuart & CSI11104
\end{tabular}


Date: $\quad$ August 17, 2011

CCA(s): CITRC

CSO: D. R. Norman
Inspector: J. T. Taylor/A. B. Hoffman

Building: 612

Organization Name: Sensor Technologies

(or representative)

\section{INSPECTION PURPOSE}

Criticality Safety Engineering inspections of CCAs are performed to determine compliance with applicable requirements and to ensure that process conditions have not changed that would alfect the Criticality Safety Evaluations (CSES).

FACILITY STATUS, SUMMARIZE CHECKLIST ACTIVITIES

Record additional information and comments on page 2. Notify facility management of any imminent safely hazards

N/A YES NO https://nucleus. inl gov/portal/server. pt?open $=512 \&$ objlD =369\&mode $=2$ )

Master list date: $\quad 05 / 02 / 2011$ replaced D. G. Blatter as Line Manager per LWP-18005

$\triangle \square$ 2. Are the boundaries identified and consistent with CCA information on file with Criticality Safety Engineering?

$\bigotimes \square$ 3. Is the most current and applicable governing criticality safety document in use at the time of this inspection of the CCA? List applicable documents (e.g., DSA, CHCS LST, or CSE)

4. If the CCA is posted, is the CCA posted correctly?

a) Is the CSO identified on posting(s) and, if applicable, Alternate?

b) Correct mass limit identified (applies to Mass CCAs only): $\leq 350 \mathrm{~g} \square$ or $\leq 250 \mathrm{~g}$ limit

5. How is inventory of fissionable material items maintained? see attached inventory form

Total(g): $536.98 \mathrm{~g}$

6. If there is a criticality control that affects emergency response, has the CSO reviewed the pre-incident plan? (on file with the INL Fire Department) $\square$ Yes $\square$ No $\quad$ Reference \#:

7. Were fissionable materials visibly labeled where practical?

8. Does the CCA have a Criticality Alarm System?

a) Are calibrations and testing current? References:

b) Are detectors free from any obstruction(s) that could impair criticality accident detection?

9. Are activities within facility, equipment, or procedures enveloped by the current and approved criticality safety documents (for example, DSAs, CSEs, applicable approval letter, and/or CHCS/LST of criticality controls) (Notify Facility management immediately if there is a safety concern) : (Describe on page 2)

10. Were observed in-progress activities in compliance with criticality safety limits? Describe details on page 2 if applicable. (Notify facility management immediately if there is a safety concern.)

11. Was satisfactory progress made on action items noted during previous inspections? Summarize items and progress on page 2 if applicable.

12. Was the facility free from observable criticality safety problems, other than those described above? Describe items on page 2 if applicable. (Notify facility management immediately if there is a safety concern.) 
CSO, Daren Norman is currently revising LI-399, "Procedure Criticality Control Areas at CITRC." The purpose of the revision is to address fissionable controls at other facilities for DTRA activities including the SOX Range. This will require development and approval of a Hazard Assessment Document, establishing a new CCA at SOX, implementation of "Criticality Safety Evaluation for the DTRA Low-Enriched Uranium Inspection Object" and a revision to JTT-05-09, "Criticality Safety Conirols for CITRC CCAs (revision 1).

It is also recommended that the U-235 equivalency be modified to be consistent with the new INL standard moderated fissionable equivalency (MFE). Criticality Safety Engineering will work closely with the CSO to modify equivalency during the review/approval of LI-399, "Procedure Criticality Control Areas at CITRC".

Summarize the changes that have been made to the facility, equipment and/or procedures since the last CCA inspection.

CSO, Daren Norman, is actively pursuing obtaining another uranium metal plate ( $\$ 200 \mathrm{~g} U-235)$ to add to his fissionable material inventory at building PER-612.

What are the current activities in the CCA? Describe: (refer to item \#9 from page 1)

The facility was undergoing a Safeguards and Security nuclear materials inventory.

None

As documented in ICAMS system per LWP-13840

(Response Due Date)

As documented elsewhere. Reference.

\begin{tabular}{|l|l|l}
\hline Report Date & Assessor(s) & Inspection Record No. \\
August 18,2011 & J. T. Taylor/A. B. Hoffman & CSI11105
\end{tabular}


Idaho National Laboratory

\begin{tabular}{|c|c|c|c|}
\hline $\begin{array}{c}\text { PROCEDURE CRITICALITY CONTROL } \\
\text { AREAS AT CITRC }\end{array}$ & $\begin{array}{l}\text { Identifier: } \\
\text { Revision: } \\
\text { Effective Date: }\end{array}$ & $\begin{array}{l}\text { LI-399 } \\
0 \\
03 / 19 / 09\end{array}$ & \\
\hline
\end{tabular}

\section{Appendix A - CITRC Criticality Control Areas Inventory Record}

Criticality Safety Officer Signature: Danen 12 Date: $8 / 17 / 2011$ Time: $13: 45$ Transfer Verification Signature: 2ffotan Date: $8-17-11$ Time: $, 3: 42$

\begin{tabular}{|l|l|l|l|l|}
\hline \multicolumn{3}{|c|}{ FACILITY - IRTTC (PBF-609, 622, 623, and 641) Inventory } \\
\hline Total U-235 Equivalent Mass must be less than 700 grams & $\begin{array}{l}\text { U-235 } \\
\text { mass (g) }\end{array}$ & $\begin{array}{l}\text { U-233, Pu-239, } \\
\text { Pu-241 mass (g) }\end{array}$ & $\begin{array}{l}\text { U-235 } \\
\text { Equivalent mass }\end{array}$ \\
\hline Item Number & Description & & \\
\hline & & & & \\
\hline & & & & \\
\hline & & & & \\
\hline & & & & \\
\hline $\begin{array}{l}\text { * NOTE : For U-233, Pu-239, and Pu-241 the mass must be multiplied } \\
\text { by 2 to obtain the U-235 Equivalency mass }\end{array}$ & Total mass (g) & \\
\hline
\end{tabular}

\section{FACILITY - SPF (PBF-612) Inventory}

Total U-235 Equivalent Mass must be less than 700 grams

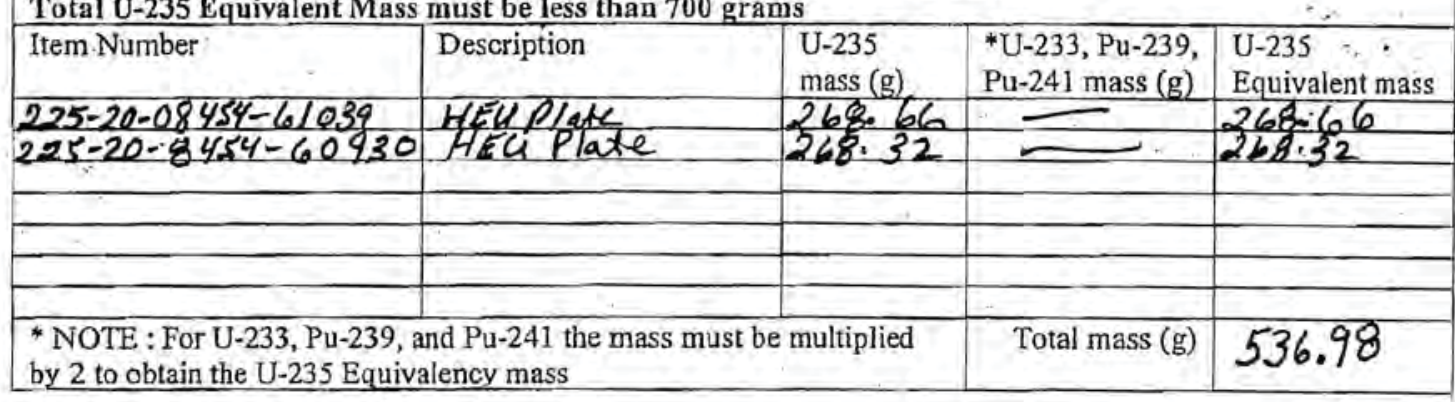

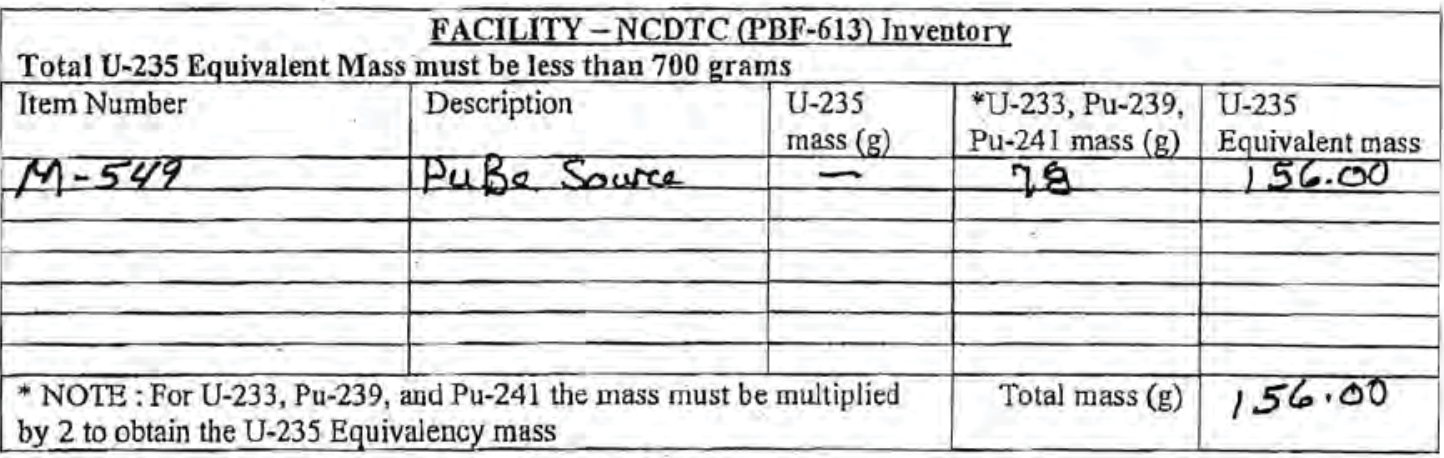

\begin{tabular}{|c|c|c|c|c|c|}
\hline \multicolumn{6}{|c|}{$\begin{array}{l}\text { Transfer Inventory } \\
\text { Total U-235 Equivalent Mass must be less than } 350 \text { grams too and from }\end{array}$} \\
\hline Item Number & From & To & $\begin{array}{l}\mathrm{U}-235 \\
\operatorname{mass}(\mathrm{g})\end{array}$ & $\begin{array}{l}{ }^{*} \mathrm{U}-233, \mathrm{Pu}-239, \\
\mathrm{Pu}-241 \text { mass }(\mathrm{g})\end{array}$ & $\begin{array}{l}\text { U-235 } \\
\text { Equivalent mass }\end{array}$ \\
\hline \multicolumn{4}{|c|}{$\begin{array}{l}\text { NOTE : For U-233, Pu-239, and Pu- } 241 \text { the mass must be multiplied } \\
\text { by } 2 \text { to obtain the U-235 Equivalency mass }\end{array}$} & Total mass (g) & \\
\hline
\end{tabular}




\section{CRITICALITY CONTROL AREA (CCA) INSPECTION CHECKLIST}

Rev. 09

Date: 6/15/2011

$\mathrm{CCA}(\mathrm{s})$ - SSPSF

CSO: R. P. Gomez

(or representative) inspector: L. R Flatten

Building: MFC-792-A

Organization Name: Fuel Manufacturing

\section{INSPECTION PURPOSE}

Criticality Safety Engineering inspections of CCAs are performed to determine compliance with applicable requirements and to ensure that process conditions have not changed that would affect the Cnticality Safety Evaluations (CSEs).

\section{FACILITY STATUS, SUMMARIZE CHECKLIST ACTIVITIES}

Record additional infomation and comments on page 2. Notify facility management of any imminent safety hazards

NIA YES NO

Х 1. is CCA information listed correctly on the CCA master list? (Access the master list via https: $/$ /nucleus. inl.gov/portal/server.pt?open=512\&objiD=369\&mode=2)

Master list dale: $\quad 6 / 09 / 2011$

$\bigotimes \square$ 2. Are the boundaries identified and consistent with CCA information on file with Criticality Safety Engineering?

Х 3. Is the most current and applicable governing criticality safety document in use at the time of this inspection of the CCA? List applicable documents (e.g., DSA, CHCS, LST, or CSE).

LST-395, Criticality Controls for SSPSF, Rev. 0, May 11, 2011

$\triangle \square \square$ 4. If the CCA is posted, is the CCA posted correctly?

a) Is the CSO identified on posting(s) and, if applicable, Alternate?

b) Correct mass limit identified (applies to Mass CCAs only) $\leq 350 \mathrm{~g} \square$ or $\leq 250 \mathrm{~g}$ limit $\square$

$\square \square$ 5. How is inventory of fissionable material items maintained? Local database

Total $(g): \underline{28 \text { pieces }}$

6. If there is a criticality control that affects emergency response, has the CSO reviewed the pre-incident plan? (on file with the INL Fire Department) $\square$ Yes $\square$ No Reference \#:

$\otimes \square \square 7$.

Were fissionable materials visibly labeled where practical? No fissionable material was visible

8. Does the CCA have a Criticality Alarm System?

a) Are calibrations and testing current? References:

b) Are detectors free from any obstruction(s) that could impair criticality accident detection?

9. Are activities within facility, equipment, or procedures enveloped by the current and approved criticality safety documents (for example, DSAS, CSEs, applicable approval letter, and/or CHCS/LST of criticality controls) (Notify Facility management immediately if there is a safety concern) : (Describe on page 2)

See page 2

10. Were observed in-progress activities in compliance with criticality safety limits? Describe details on page 2 if applicable. (Notify facility management immediately if there is a safety concern.)

11. Was satisfactory progress made on action items noted during previous inspections? Summarize items and progress on page 2 if applicable.

12. Was the facility free from observable criticality safety problems, other than those described above? Describe items on page 2 if applicable. (Notify facility management immediately if there is a safety concern.) 


\section{ADDITIONAL INFORMATION AND COMMENTS}

5- Controls based on item piece counts. Locally controlled Access Database maintains inventory of material.

Summarize the changes that have been made to the facility, equipment and/or procedures since the last CCA inspection.

The upgraded Documented Safety Analysis (SAR/TSR-408) was approved by DOE December 2010 and implemented in the facility May 11, 2011. LST -395, Criticality Controls for SSPSF, was created and identified controls are implemented through SSPSF-OI21160, Nuclear-Material Handling, and FRM-550, SSPSF Nuclear Material Transfer Form.

What are the current activities in the CCA? Describe: (refer to item \#9 from page 1)

- Maintenance activities were in progress in SSPSF at the time of the inspection.

A new glovebox for the building of Stirling Generators is being installed within the SSPSF to be completed in FY-11. Use of the new glovebox in FY-12 will introduce vaporized Hydrogen Peroxide into the facility.

- There is one Advanced Stirling Radioisotope Generator (ASRG) build planned in SSPSF for FY-12.

区 None

As documented in ICAMS system per LWP-13840

As documented elsewhere. Reference:

Report Date

$6 / 16 / 2011$

\section{Assessor(s)}

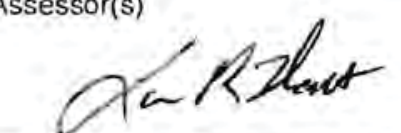

Inspection Record No.

$$
C S I / 1106
$$


Date: Seplember 13, 2011

CCA(s): FASB

CSO: J.J.Green

(or representative)
Inspector A. B. Hoffman/J. T. Taylor

Building MFC/ANL W-787

Organization Name: FASB/EML/RCL/CESB Operations

\section{INSPECTION PURPOSE}

Crilicality Safely Engineering inspections of CCAs are performed to detemine compliance with applicable requirements and to ensure that process conditions have not changed that would affect the Criticality Safety Evaluations (CSEs).

\section{FACILITY STATUS, SUMMARIZE CHECKLIST ACTIVITIES}

Record additional information and comments on page 2. Notify facility management of any imminent safety hazards

N/A YES NO

$\triangle \square$ 1. Is CCA information listed correclly on the CCA master list? (Access the master list via https://nucleus. inl.gov/portal/server. pt?open=512\&objl $D=369 \&$ mode=2)

Master list date: $\quad 08 / 31 / 11$

$\bigotimes \square$ 2. Are the boundaries identified and consistent with CCA information on file with Criticality Safety Engineering?

$\bigotimes$ 3. Is the most current and applicable governing criticality safety document in use at the time of this inspection of the CCA? List applicable documents (e.g., DSA, CHCS, LST, or CSE).

INL/INT-10-18996,"Criticality Safety Evaluation for 700 Gram Moderated Fissionable Equivalent (MFE) Criticality Control Areas (CCAs)", SD-37.1.4 "Radiological Material Tracking For FASB/EML/RCL/CESB

4. If the CCA is posted, is the CCA posted correctly?

a) Is the CSO identified on posting(s) and, if applicable, Alternate?

b) Correct mass limit identified (applies to Mass CCAs only): $\leq 350 \mathrm{~g} \square$ or $\leq 250 \mathrm{~g}$ limit

5. How is inventory of fissionable material items maintained? CSO maintains inventory in electronic Database Total $(\mathrm{g}): \quad 555.82 \mathrm{~g}$

6. If there is a criticality control that affects emergency response, has the CSO reviewed the pre-incident plan? (on file with the INL Fire Department) $\square$ Yes $\square$ No $\quad$ Reference \#.

7. Were fissionable materials visibly labeled where practical?

8. Does the CCA have a Criticality Alarm System?

a) Are calibrations and testing current? References:

b) Are detectors free from any obstruction(s) that could impair criticality accident detection?

\ 9. Are activities within facility, equipment, or procedures enveloped by the current and approved criticality safety documents (for example, DSAs, CSEs, applicable approval letter, and/or CHCS/LST of criticality controls) (Notify Facility management immediately if there is a safety concern): (Describe on page 2)

10. Were observed in-progress activities in compliance with criticality safety limits? Describe details on page 2 if applicable. (Notify facility management immediately if there is a safety concern.)

$\triangle \square$ 11. Was satisfactory progress made on action items noled during previous inspections? Summarize items and progress on page 2 if applicable.

D 12. Was the facility free from observable criticality safely problems, other than those described above? Describe items on page 2 if applicable. (Notify facility management immediately if there is a safety concern.) 
Summarize the changes that have been made to the facility, equipment and/or procedures since the last CCA inspection. N/A

What are the current activities in the CCA? Describe: (refer to item \#9 from page 1)

CSO J. Green states that waste drums usually go to directly to ORSA and are not kept at FASB.

$\triangle$ None

As documented in ICAMS system per LWP-13840

As documented elsewhere. Reference:

\begin{tabular}{l|l|l}
\hline Report Date & Assessor(s) & Inspection Record No. \\
September 13,2011 & A. B. Hoffman & CSI11107
\end{tabular}


FASB CCA inventory Summary

\author{
LEU $\quad 253.13$ \\ HEU 299.13 \\ Hold-Up $3.56 \mathrm{~g}$ \\ Total $\quad 555.82$
}


This page intentionally blank 


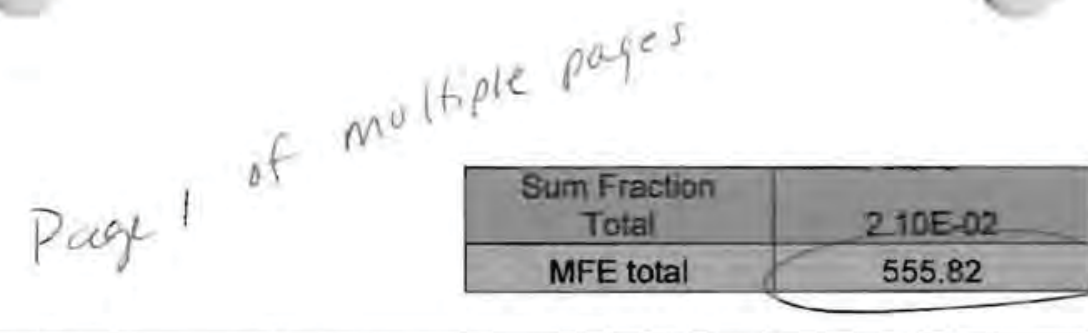

INVENTORY

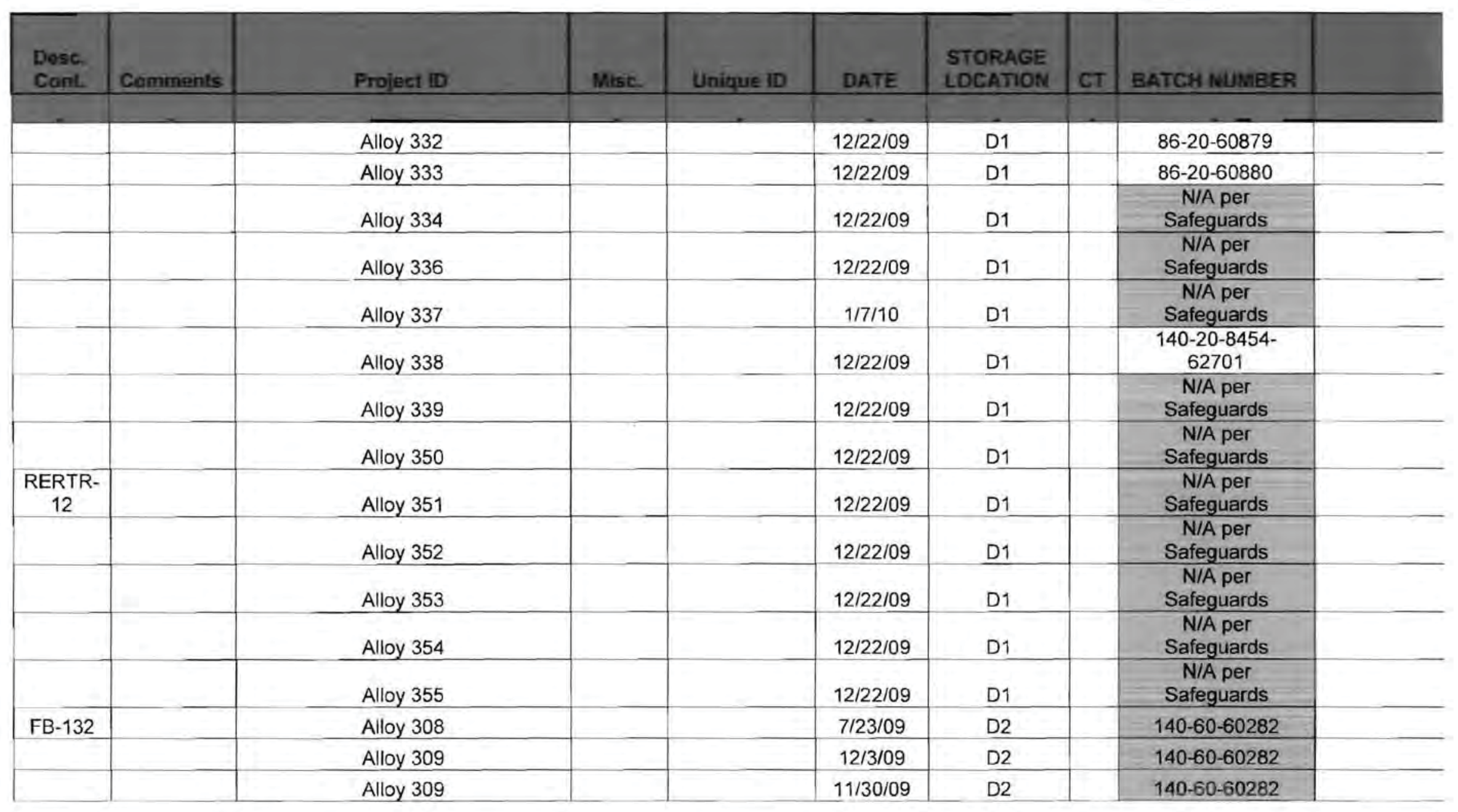




\begin{tabular}{|l|l|l|l|l|l|l|l|}
\hline & Alloy 309 & & & $11 / 30 / 09$ & D2 & $140-60-60282$ & \\
\hline & Alloy 309 & & & $11 / 30 / 09$ & D2 & $140-60-60282$ & \\
\hline & Alloy 309 & & & $1 / 7 / 10$ & D2 & $140-60-60282$ & \\
\hline
\end{tabular}


431.03 CRITICALITY CONTROL AREA (CCA) INSPECTION CHECKLIST

Rev. 09

Page 1 of 3

Date: June 1, 2011

CCA(s): HFEF

CSO. K. L. Kynasten (or representative)
Inspector: A. Hoffman/C. E. Stuart

Building: MFC-785

Organization Name: Hot Cell Services

\section{INSPECTION PURPOSE}

Criticality Safety Engineening inspections of CCAs are performed to delermine compliance with applicable requirements and to ensure that process conditions have not changed that would affect the Criticality Safety Evaluations (CSES)

FACILITY STATUS, SUMMARIZE CHECKLIST ACTIVITIES

Record additional information and comments on page 2. Notify facility management of any imminent safety hazards

N/A YES NO

$\bigotimes \square$ 1. Is CCA information listed correctly on the CCA master list? (Access the master list via https://nucleus.inl.gov/portal/server.pt?open=512\&.obj|D=369\&mode=2)

Master list date: $\quad$ 05/02/2011

2. Are the boundaries identified and consistent with CCA information on file with Criticality Safety Engineering? HFEF building

3. Is the most current and applicable governing criticality safety document in use at the time of this inspection of the CCA? List applicable documents (e.g., DSA, CHCS, LST, or CSE),

HFEF-OI-1020-Rev 8

$\triangle \square$ 4. If the CCA is posted, is the CCA posted correctiy?

a) Is the CSO identified on posting(s) and, if applicable, Alternate?

b) Correct mass limit identified (applies to Mass CCAs only): $\leq 350 \mathrm{~g} \square$ or $\leq 250 \mathrm{~g}$ limit $\square$

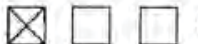

5. How is inventory of fissionable material items maintained?

Total $(\mathrm{g})$ : HFEF is a procedure CCA

$\mathrm{Q} \square \square$

6. If there is a criticality control that affects emergency response, has the CSO reviewed the pre-incident plan? (on file with the INL Fire Department) $\square$ Yes $\square$ No Reference \#: Pre incident Plan MFC-785 HFEF

7. Were fissionable materials visibly labeled where practical?

8. Does the CCA have a Criticality Alarm System?

a) Are calibrations and testing current? References:

b) Are detectors free from any obstruction(s) that could impair criticality accident detection?

9. Are activities within facility, equipment, or procedures enveloped by the current and approved criticality safety documents (for example, DSAs, CSES applicable approval letter, and/or CHCS/LST of criticality controls) (Notify Facility management immediately if there is a safety concern) : (Describe on page 2)

10. Were observed in-progress activities in compliance with criticality safety limits? Describe details on page 2 if applicable. (Notify facility management immediately if there is a safety concern.)

11. Was satisfactory progress made on action items noted during previous inspections? Summarize items and progress on page 2 if applicable.

Х 12. Was the facility free from observable criticality safety problems, other than those described above? Describe items on page 2 if applicable. (Notify facility management immediately if there is a safety concern.) 


\section{ADDITIONAL INFORMATION AND COMMENTS}

1) The 2010 CCA inspection (CSI10109) noted Rick Casler as acting CSO, while K. L. Kynasten was completing training to qualify as IFEF CSO. K. L. Kynasten has completed all required CSO training. The current CCA master list identifies K. L. Kynasten as the HFEF CSO.

2) The 2010 CCA inspection recommended a revision to the CHCS to clarify the definition of "moderator". This change has been incorporated into Revision 8 of the HFEF CHCS.

Summarize the changes that have been made to the facility, equipment and/or procedures since the last CCA inspection.

1) The FACS furnace is being installed in Zone $6 \mathrm{M}$. The HFEF CHCS has already been revised to cover the new equipment and process within the zone.

2) $\mathrm{CHCS}$ has been revised (see item number 2 , above)

What are the current activities in the CCA? Describe: (refer to item \#9 from page 1)

1) Assay work was being performed in Zone $7 \mathrm{M}$. Assay work involved a single FFTF limit and was within limits for Zone $7 \mathrm{M}$.

$\triangle$ None

$\square$ As documented in ICAMS system per LWP-13840

As documented elsewhere. Reference:

\begin{tabular}{|l|l|l|l}
\hline Report Date & Assessor(s) \\
June 7, 2011 & Inspection Record No. E. Stuart
\end{tabular}


Date: April, 28, 2011

CCA(s): ZPPR Workroom, Vault, Cell

CSO: C.S. Brower
Inspector: W. W. Scates

Building: MFC-775/776

Organization Name: Fuel Manufacturing

(or representative)

INSPECTION PURPOSE

Criticality Safety Engineering inspections of CCAs are performed to determine compliance with applicable requirements and to ensure that process conditions have not changed that would affect the Criticality Safety Evaluations (CSES).

\section{FACILITY STATUS, SUMMARIZE CHECKLIST ACTIVITIES}

Record additional informatıon and comments on page 2. Notify facility management of any imminent safely hazards

N/A YES NO

区 $\square$ 1. Is CCA information listed correctly on the CCA master list? (Access the master list via $\mathrm{https}$ //nucleus inl gov/portal/server . pt?open=512\&objl $=369 \&$ mode $=2$ )

Master list date: $\quad 3 / 23 / 11$

$\triangle \square$ 2. Are the boundaries identified and consistent with CCA information on file with Criticality Safety Engineering? ZPPR Workroom, Vault, Cell

$\bigotimes \square$ 3. Is the most current and applicable governing criticality safety document in use at the time of this inspection of the CCA? List applicable documents (e.g., DSA, CHCS, LST, or CSE).

W0430-0006-KH Rev. 3 8/3/2010

If the CCA is posted, is the CCA posted correctly?

a) is the CSO identified on posting(s) and, if applicable, Alternate?

b) Correct mass limit identified (applies to Mass CCAs only): $\leq 350 \mathrm{~g} \square$ or $\leq 250 \mathrm{~g}$ limit

5. How is inventory of fissionable material items maintained? Safeguards Database

Total(g):

. If there is a criticality control that affects emergency response, has the CSO reviewed the pre-incident plan? (on file with the INL Fire Department) $\square$ Yes $\square$ No Reference \#: ANL-W 775 ZPPR Workroom/ Experiment Room ZX-MIA-708A \& 708B

ANL-W 776 Zero Power Physics Reactor Cell ZX-MIA-706A \& 706B

$\square \square \square 7$. $\square \triangle_{\square}^{\square} \square$

Were fissionable materiais visibly labeled where practical?

B. Does the CCA have a Criticality Alarm System?

a) Are calibrations and testing current? References: See Attached

b) Are detectors free from any obstruction(s) that could impair criticality accident detection?

9. Are activities within facility, equipment, or procedures enveloped by the current and approved criticality safety documents (for example, DSAs, CSEs, applicable approval letter, and/or CHCS/LST of criticality controls) (Notify Facility management immediately if there is a safety concern): (Describe on page 2)

ZPPR-OI-005

10. Were observed in-progress activities in compliance with criticality safety limits? Describe details on page 2 if applicable. (Notify facility management immediately if there is a safety concern.)

11. Was satisfactory progress made on action items noted during previous inspections? Summarize items and progress on page 2 if applicable. 
邓 12. Was the facility free from observable criticality safety problems, other than those described above? Describe items on page 2 if applicable. (Notify facility management immediately if there is a safety concern.)

Summarize the changes that have been made to the facility, equipment and/or procedures since the last CCA inspection.

\section{What are the current activities in the CCA? Describe: (refer to item \#9 from page 1)}

Repacking Clamshelis

\section{ACTION ITEM (Improvements, corrections, etc)}

$\bigotimes$ None

As documented in ICAMS system per LWP-13840

As documented elsewhere. Reference: 
431.03

05/10/2010

Rev. 09

CRITICALITY CONTROL AREA (CCA) INSPECTION CHECKLIST

\begin{tabular}{|c|c|c|}
\hline Report Date & Assessor(s) & Inspection Record No. \\
$4 / 28 / 11$ & C I 11110 \\
\hline
\end{tabular}


Date: September 14,2011

CCA(s): EDL

CSO: J. J.Green

(or representative)
Inspector: A. B. Hoffman

Building: MFCIANL-W 1702

Organization Name: FASB/EML/RCL/CESB Operations

\section{INSPECTION PURPOSE}

Criticality Safety Engineening inspections of CCAs are performed to determine compliance with applicable requirements and to ensure that process conditions have not changed that would affect the Crificality Safety Evaluations (CSES).

\section{FACILITY STATUS, SUMMARIZE CHECKLIST ACTIVITIES}

Record additional information and comments on page 2. Notify facility management of any imminent safety hazards

N/A YES NO

1. Is CCA information listed correctly on the CCA master list? (Access the master list via https://nucleus. inl.gov/portal/server. pt?open=512\&objlD=369\&mode=2)

Master list date: $\quad 8 / 31 / 11$ (the following correction was made: S. L. Winn has replaced C. Collard as Line Manager of this CCA)

$\triangle$ 2. Are the boundaries identified and consistent with CCA information on file with Criticality Safety Engineering?

$\triangle \square$

3. Is the most current and applicable governing criticality safety document in use at the time of this inspection of the CCA? List applicable documents (e.g., DSA, CHCS, LST, or CSE)

LWP-18003

4. If the CCA is posted, is the CCA posted correctly?

a) Is the CSO identified on posting(s) and, if applicable, Alternate?

b) Correct mass limit identified (applies to Mass CCAs only): $\leq 350 \mathrm{~g} \square$ or $\leq 250 \mathrm{~g}$ limit $\square$ See Back

5. How is inventory of fissionable material items maintained? Electronic database Total(g): $\quad 0$ grams

D $\square$ 6. If there is a criticality control that affects emergency response, has the CSO reviewed the pre-incident plan? (on file with the INL Fire Department) $\square$ Yes $\square$ No Reference \#.

7. Were fissionable materials visibly labeled where practical?

8. Does the CCA have a Criticality Alarm System?

a) Are calibrations and testing current? References:

b) Are detectors free from any obstruction(s) that could impair criticality accident detection?

9. Are activities within facility, equipment, or procedures enveloped by the current and approved criticality safety documents (for example. DSAs, CSES, applicable approval letter, and/or CHCS/LST of criticality controls) (Notify Facility management immediately if there is a safety concern) : (Describe on page 2)

CCA is used for radiography of material from FASB CCA

$凶 \square$ 10. Were observed in-progress activities in compliance with criticality safety limits? Describe details on page 2 if applicable. (Notify facility management immediately if there is a safety concern.)

11. Was satisfactory progress made on action items noted during previous inspections? Summarize items and progress on page 2 if applicable.

$\square$ 12. Was the facility free from observable criticality safety problems, other than those described above? Describe items on page 2 if applicable. (Notify facility management immediately if there is a safely concern.) 


\section{ADDITIONAL INFORMATION AND COMMENTS}

4. b) The posting on the CCA door was outdated (Rev 5) and was immediately replaced with a new sign (Rev 6 ) by the CSO (J. Green) during the inspection. No further action is required.

Summarize the changes that have been made to the facility, equipment and/or procedures since the last CCA inspection NIA

What are the current activities in the CCA? Describe: (refer to item \#9 from page 1)

EDL was established a CCA for radiography of material from FASB. The facility contained no material at the time of the inspection.

None

$\square$ As documented in ICAMS system per LWP-13840

As documented elsewhere. Reference 


$$
\begin{gathered}
\text { EDL Summary Sheet } \\
\text { LEU Og } \\
\text { HEU Og } \\
\text { Hold-Up } \text { Og } \\
\text { Total }=0 \mathrm{~g}
\end{gathered}
$$




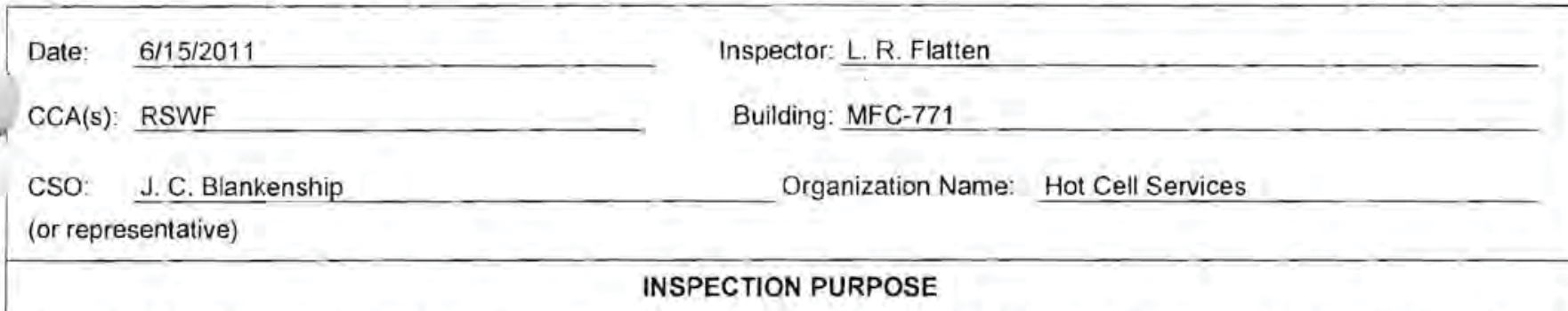

Criticality Safety Engineering inspections of CCAs are performed to determine compliance with applicable requirements and to ensure that process conditions have nol changed that would affect the Criticality Safety Evaluations (CSEs).

FACILITY STATUS, SUMMARIZE CHECKLIST ACTIVITIES

Record additional information and comments on page 2. Notify facility management of any imminent safety hazards

N/A YES NO

D 1. Is CCA information listed correctly on the CCA master list? (Access the master list via https: $/$ /nucleus. inl.gov/portal/server.pt?open $=512 \&$ objlD=369\&mode=2)

Master list date: $\quad 6 / 09 / 2011$

D. 2. Are the boundaries identified and consistent with CCA information on file with Criticality Safety Engineering?

$\triangle$ 3. Is the most current and applicable governing criticality safety document in use at the time of this inspection of the CCA? List applicable documents (e.g., DSA, CHCS, LST, or CSE).

LST-391, Radioactive Scrap and Waste Facility (MFC-771) Criticality Control List, Rev. 1, March 02, 2011

$\triangle \square \square$ 4. If the CCA is posted, is the CCA posted correctly?

a) Is the CSO identified on posting(s) and, if applicable, Alternate?

b) Correct mass limit identified (applies to Mass CCAs only): $\leq 350 \mathrm{~g} \square$ or $\leqslant 250 \mathrm{~g}$ limit

5. How is inventory of fissionable material items maintained? Liner records maintained at TSD Facilities Total $(g):$ N/A

6. If there is a criticality control that affects emergency response, has the CSO reviewed the pre-incident plan? (on file with the INL Fire Departmenl) $\square$ Yes $\square$ No $\quad$ Reference \#

7. Were fissionable materials visibly labeled where practical? Underground storage of fissionable material

8. Does the CCA have a Criticality Alarm System?

a) Are calibrations and testing current? References:

b) Are detectors free from any obstruction(s) that could impair criticality accident detection?

9. Are activities within facility, equipment, or procedures enveloped by the current and approved criticality safety documents (for example, DSAs, CSES, applicable approval letter, and/or CHCS/LST of criticality controls) (Notify Facility management immediately if there is a safety concern) : (Describe on page 2)

See page 2

10. Were observed in-progress activities in compliance with criticality safety limits? Describe details on page 2 if applicable. (Notify facility management immediately if there is a safety concern.)

11. Was satisfactory progress made on action items noted during previous inspections? Summarize items and progress on page 2 if applicable.

$\bigotimes \square$ 12. Was the facility free from observable criticality safety problems, other than those described above? Describe items on page 2 if applicable. (Notify facility management immediately if there is a safety concern.) 
Rev. 09

\section{ADDITIONAL INFORMATION AND COMMENTS}

i- Controls based on package and configurations per liner. Individual liner records are kept at Treatment Storage and Disposal (TSD) Facilities offices.

Summarize the changes that have been made to the facility, equipment and/or procedures since the last CCA inspection.

A gate has been added to the North portion of the security fence. Twelve liners have been excavated and removed from the facility, the holes were backfilled with soil.

LST-391, Radioactive Scrap and Waste Facility (MFC-771) Criticality Control List, was revised March 02, 2011 to allow removal of SNL Transport Containers.

What are the current activities in the CCA? Describe; (refer to item \#9 from page 1)

- Continuing RH-TRU waste retrievals for disposal. Twenty one RH-TRU retrievals have been completed in FY-11; 12 large liners, 8 SLSF waste cans and the EBR-11 Donut. One more item to be removed in FY-11 to meet milestone.

- Removal of SNL Transport Containers scheduled for the week of June $20^{\text {th }}$.

- Storage of remote handled waste.

- Retrieval of EBR-II spent fuel for processing at FCF.

$\bigotimes$ None

$\square$ As documented in ICAMS system per LWP-13840

As documented elsewhere. Reference:

Report Date Assessor(s)
Inspection Record No. 


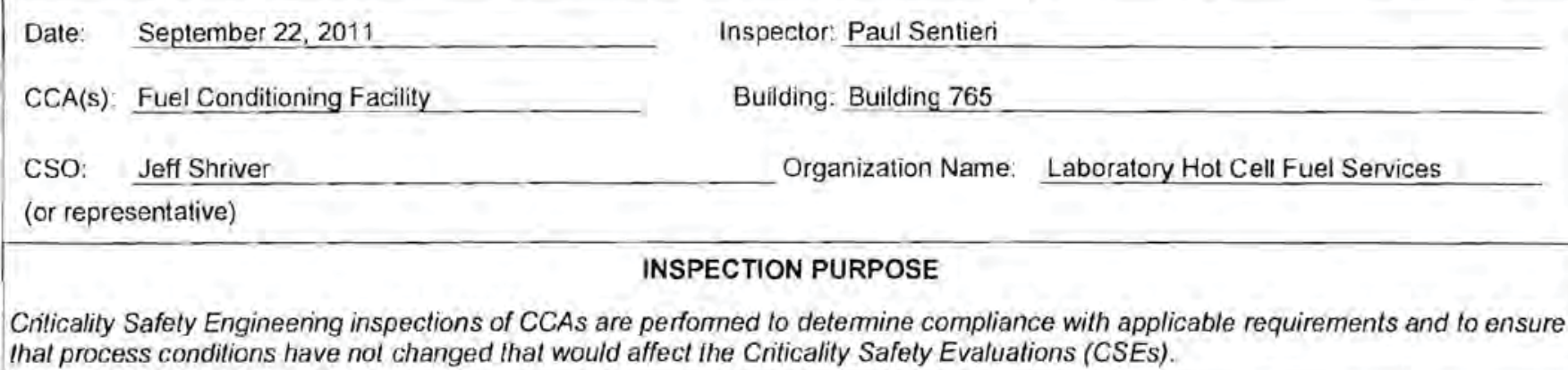

that process conditions have not changed that would affect ihe Criticality Safety Evaluations (CSES).

FACILITY STATUS, SUMMARIZE CHECKLIST ACTIVITIES

Record additional information and comments on page 2. Notify facility management of any imminent safety hazards

NIA YES NO

$\triangle \square$ 1. Is CCA information listed correctly on the CCA master list? (Access the master list via https://nucleus inl,gov/portal/server.pt?open $=512 \&$ objlD $=369 \&$ mode $=2$ )

Master list date: September 19,2011.

2. Are the boundaries identified and consistent with CCA information on file with Criticality Safety Engineering?

3. Is the most current and applicable governing criticality safety document in use at the time of this inspection of the CCA? List applicable documents (e.g., DSA, CHCS, LST, or CSE).

F0000-0026-ES, "Fuel Conditioning Facility Criticality Control Hazards Statement". Rev. 39, August 8, 2011.

4. If the CCA is posted, is the CCA posted correctly?

a) Is the CSO identified on posting(s) and, if applicable, Alternate?

b) Correct mass limit identified (applies to Mass CCAs only): $\leq 350 \mathrm{~g} \square$ or $\leq 250 \mathrm{~g}$ limit

5. How is inventory of fissionable material items maintained?

FCF is a Procedure CCA fissonable material tracked in Material Tracking System and listed at workstations in Zone Inventory Postiings.

Total(g): N/A

6. If there is a criticality control that affects emergency response, has the CSO reviewed the pre-incident plan? (on file with the INL Fire Department) $\square$ Yes $\square$ No

Reference \#: Pre-Incident Plan, MFC 765 Fuel Cinditioning Facility, Effective Date September 2011

7. Were fissionable materials visibly labeled where practical? Inventories for zones posted at each zone location.

8. Does the CCA have a Criticality Alarm System?

a) Are calibrations and testing current? References:

FCF-MI-8630A, WO 153721 Completed on March 29, 2011

b) Are detectors free from any obstruction(s) that could impair criticality accident detection?

9. Are activities within facility, equipment, or procedures enveloped by the current and approved criticality safety documents (for example, DSAs, CSEs, applicable approval letter, and/or CHCS/LST of criticality controls) (Notify Facility management immediately if there is a safety concern) : (Describe on page 2)

10. Were observed in-progress activities in compliance with criticality safety limits? Describe details on page 2 if applicable. (Notify facility management immediately if there is a safety concern.)

11. Was satisfactory progress made on action items noted during previous inspections? Summarize items and progress on page 2 if applicable 
431.03

$05 / 10 / 2010$

Rev. 09

\section{CRITICALITY CONTROL AREA (CCA) INSPECTION CHECKLIST}

Page 2 of 4

Х 12. Was the facility free from observable criticality safety problems, other than those described above? Describe items on page 2 if applicable. (Notify facility management immediately if there is a safety concern.)

\section{ADDITIONAL INFORMATION AND COMMENTS}

Reviewed all Posted Operator Aids (POAs) and were found to be current.

The criticality detector unit in the RLWS is in a contamination area whithin a shielded room. Visual inspection of the unit was not possible at the time of the inspection. All other units were free from obstructions. It should be noted that the criticaltiy alarm system will be removed with the implementation of the new DSA.

\#6 As previously noted CSI(10113) firefighting restriction in the pre-incident fire plan restricts water in the SERA and high bay during fire fighting activities. This restriction is not being driven by criticality prevention therefore no change to the pre-incident fire plan is necessary.

Summarize the changes that have been made to the facility, equipment and/or procedures since the last CCA inspection.

What are the current activities in the CCA? Describe: (refer to item \#9 from page 1)

Conditoning of spent sodium bonded fuel for storage.

$\triangle$ None

As documented in ICAMS system per LWP-13840

As documented elsewhere. Reference: 
431.03

$05 / 10 / 2010$

Rev. 09

\section{CRITICALITY CONTROL AREA (CCA) INSPECTION CHECKLIST}

Report Date
Paul Sentieri

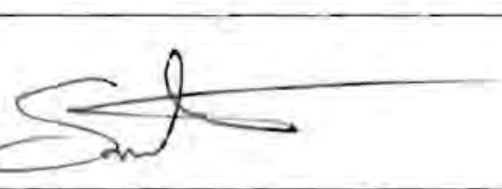

Inspection Record No. 


\begin{tabular}{l} 
Date: 9/14/2011 \\
CCA(s): Analytical Laboratories \\
CSO G. Inspector: L. R. Flatten \\
(or representative) \\
\hline \\
$\begin{array}{l}\text { Criticality Safety Engineening inspections of CCAs are performed to determine compliance with applicable requirements and to ensure } \\
\text { that process conditions have not changed that would affect the Cnticality Safety Evaluations (CSES). }\end{array}$
\end{tabular}

\section{FACILITY STATUS, SUMMARIZE CHECKLIST ACTIVITIES}

Record additional information and comments on page 2. Notify facility management of any imminent safety hazards

N/A YES NO

$\triangle \square$ 1. Is CCA information listed correctly on the CCA master list? (Access the master list via https://nucleus . inl gov/portal/server pt?open=512\&objlD=369\&mode=2)

Master list date: $\quad 8 / 31 / 2011$

$\triangle \square$ 2. Are the boundaries identified and consistent with CCA information on file with Criticality Safety Engineering?

$\triangle \square$ 3. Is the most current and applicable governing criticality safety document in use at the time of this inspection of the CCA? List applicable documents (e.g., DSA, CHCS, LST, or CSE).

INL/NT-08-14953, Criticality Safety Evaluation for Analytical Laboratories

$\triangle \square \square$ 4. If the CCA is posted, is the CCA posted correctly?

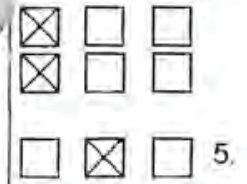

a) Is the CSO identified on posting(s) and, if applicable, Alternale?

b) Correct mass limit identified (applies to Mass CCAs only): $\leq 350 \mathrm{~g} \square$ or $\leq 250 \mathrm{~g}$ limit $\square$

5. How is inventory of fissionable material items maintained? Excel Spreadsheet

Total(g): $673.4 \mathrm{~g}$ - Facility

$\leq 350 \mathrm{~g}$ per zone

$\bigotimes \square \square 6$. If there is a criticality control that affects emergency response, has the cso reviewed the pre-incident plan? (on file with the INL Fire Department) $\square$ Yes $\square$ No Reference \#:

$\triangle \square \square 7$. Were fissionable materials visibly labeled where practical? No fissionable material was visible.

8. Does the CCA have a Criticality Alarm System?

a) Are calibrations and testing current? References:

b) Are detectors free from any obstruction(s) that could impair criticality accident detection?

9. Are activities within facility, equipment, or procedures enveloped by the current and approved criticality safety documents (for example, DSAs, CSEs, applicable approval letter, and/or CHCS/LST of criticality controls) (Notify Facility management immediately if there is a safety concern) : (Describe on page 2)

10. Were observed in-progress activities in compliance with criticality safety limits? Describe details on page 2 if applicable. (Notify facility management immediately if there is a safety concern.)

11. Was safisfactory progress made on action items noted during previous inspections? Summarize items and progress on page 2 if applicable.

12. Was the facility free from observable criticality safety problems, other than those described above? Describe items on page 2 if applicable. (Notify facility management immediately if there is a safety concern.) 


\section{ADDITIONAL INFORMATION AND COMMENTS}

11 - Portable waste water tank is still in use in the transfer zone. Work continues on installation of new waste water tanks. Facility identified there is no fissionable material in portable waste water tank. Implementation of new controls associated with SAR-401 will include tracking of fissionable material hold-up in equipment to include waste water tanks.

Summarize the changes that have been made to the facility, equipment and/or procedures since the last CCA inspection Work continues to replace waste water tanks in the basement of AL.

Several new pieces of scientific equipment have been and continue to be installed in the facility.

What are the current activities in the CCA? Describe: (refer to item \#9 from page 1)

Normal laboratory analysis operations.

AL will implement upgraded DSA (SAR-401) to include simplified criticality control in FY-12.

Note: SAR-401 submitted to DOE for approval in FY-11

As documented in ICAMS system per LWP-13840

As documented elsewhere. Reference;

\begin{tabular}{|l|l|l}
\hline Report Date & Assessor(s) & Inspection Record No. \\
$9 / 15 / 2011$ & Loren R. Flatten & C S IIIIAf
\end{tabular}




\section{Date: September 13, 2011}

CCA(s): TREAT Warehouse

CSO J. L. Shriver (or representative)
Inspector: Wade Scates

Building MFC 723

Organization Name: Hot Cell Services

\section{INSPECTION PURPOSE}

Criticality Safety Engineering inspections of CCAs are performed to determine compliance with applicable requirements and to ensure that process conditions have not changed that would affect the Criticality Safety Evaluations (CSES).

\section{FACILITY STATUS, SUMMARIZE CHECKLIST ACTIVITIES}

Record additional information and comments on page 2. Notify facility management of any imminent safely hazards

NIA YES NO

$\square$ 1. Is CCA information listed correctly on the CCA master list? (Access the master list via https: $/ /$ nucleus.inl.gov/portal/server. pt?open $=512 \&$ objlD $=369 \&$ mode $=2$ )

Master list date: $\quad 8 / 31 / 2011$

Х 2. Are the boundaries identified and consistent with CCA information on file with Criticality Safety Engineering?

3. Is the most current and applicable governing criticality safety document in use at the time of this inspection of the CCA? List applicable documents (e,g., DSA, CHCS, LST, or CSE).

TREAT-10-1017. "Criticality Hazards Control Statement for TREAT Warhouse (BLDG 723)"

4. If the CCA is posted, is the CCA posted correctly?

a) Is the CSO identified on posting(s) and, if applicable, Alternate?

b) Correct mass limit identified (applies to Mass CCAs only): $\leq 350 \mathrm{~g} \square$ or $\leq 250 \mathrm{~g}$ limit

$\otimes \square \square 5$

5. How is inventory of fissionable material items maintained? TREAT Warehouse is a Procedure CCA Total $(\mathrm{g})$ :

6. If there is a criticality control that affects emergency response, has the CSO reviewed the pre-incident plan? (on file with the INL Fire Department) $\square$ Yes $\square$ No Reference \#

7. Were fissionable materials visibly labeled where praclical?

X)

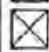
$\square \frac{\square}{\square}$

8. Does the CCA have a Criticality Alarm System?

a) Are calibrations and testing current? References;

b) Are detectors free from any obstruction(s) that could impair criticality accident detection?

9. Are activities within facility, equipment, or procedures enveloped by the current and approved criticality safety documents (for example, DSAs, CSEs, applicable approval letter, and/or CHCS/LST of criticality controls) (Notify Facility management immediately if there is a safety concern) : (Describe on page 2)

10. Were observed in-progress activities in compliance with criticality safety limits? Describe details on page 2 if applicable. (Notify facility management immediately if there is a safety concern.)

11. Was satisfactory progress made on action items noted during previous inspections? Summarize items and progress on page 2 if applicable.

12. Was the facility free from observable criticality safety problems, other than those described above? Describe items on page 2 if applicable. (Notify facility management immediately if there is a safety concern.) 
431.03

$05 / 10 / 2010$

Rev. 09

\section{CRITICALITY CONTROL AREA (CCA) INSPECTION CHECKLIST}

Page 2 of 3

Summarize the changes that have been made to the facility, equipment and/or procedures since the last CCA inspection.

\section{no changes}

What are the current activities in the CCA? Describe: (refer to item \#9 from page 1)

no activities

$\triangle$ None

As documented in ICAMS system per LWP-13840

As documented elsewhere. Reference:

\begin{tabular}{|l|l|l}
\hline Report Date & Assessor(s) & \\
CSII111115
\end{tabular}


Date: September 13,2011

CCA(s): TREAT

CSO: Kent L Brinker

(or representative)
Inspector: Ning Zhang and Paul Sentieri

Building: MFC 720

Organization Name: Laboratory Hot Cell Services

\section{INSPECTION PURPOSE}

Criticality Safety Engineering inspections of CCAs are performed to determine compliance with applicable requirements and to ensure that process conditions have not changed that would affect the Criticality Safety Evaluations (CSES).

FACILITY STATUS, SUMMARIZE CHECKLIST ACTIVITIES

Record additional information and comments on page 2. Notify facility management of any imminent safety hazards

N/A YES NO

Х 1. Is CCA information listed correctly on the CCA master list? (Access the master list via https://nucleus, inl.gov/portal/server.pt?open=512\&objlD=369\&mode=2)

Master list date: $\quad$ August 31,2011

X $\square$ 2. Are the boundaries identified and consistent with CCA information on file with Criticality Safety Engineering?

$\triangle$ 3. Is the most current and applicable governing criticality safety document in use at the time of this inspection of the CCA? List applicable documents (e.g., DSA, CHCS, LST, or CSE).

"Criticality Hazards Control Statement for TREAT Reactor Building 720", Rev, 5, Effective date 05/25/2011

$\triangle \square \square$ 4. If the CCA is posted, is the CCA posted correctly?

a) Is the CSO identified on posting(s) and, if applicable, Alternate?

b) Correct mass limit identified (applies to Mass CCAs only): $\leq 350 \mathrm{~g} \square$ or $\leq 250 \mathrm{~g} \mathrm{limit}$

$\triangle \square \square$ 5. How is inventory of fissionable material items maintained?

TREAT is a procedure CCA inventory is tracked in an Access Database

Total(g):

6. If there is a criticality control that affects emergency response, has the CSO reviewed the pre-incident plan? (on file with the INL Fire Department) $\square$ Yes $\square$ No Reference \#: Pre-Incident Plan, MFC 720 TREAT Facility Reactor Building, June 2008

7. Were fissionable materials visibly labeled where practical?

8. Does the CCA have a Criticality Alarm System?

a) Are calibrations and testing current? References:

SEe ADDITIONAL INFORMATION AND COMMENTS Seclion

b) Are detectors free from any obstruction(s) that could impair criticality accident delection?

9. Are activities within facility, equipment, or procedures enveloped by the current and approved criticality safety documents (for example, DSAs, CSEs, applicable approval letter, and/or CHCS/LST of criticality controls) (Notify Facility management immediately if there is a safety concern) : (Describe on page 2)

10. Were observed in-progress activities in compliance with criticality safety limits? Describe details on page 2 if applicable. (Notify facility management immediately if there is a safety concern.)

11. Was satisfactory progress made on action items noted during previous inspections? Summarize items and progress on page 2 if applicable.

Х 12. Was the facility free from observable criticality safety problems, other than those described above? Describe items on page 2 if applicable. (Notify facility management immediately if there is a safety concern.) 
431.03

05/10/2010

CRITICALITY CONTROL AREA (CCA) INSPECTION CHECKLIST

Rev. 09

Page 2 of 3

\section{ADDITIONAL INFORMATION AND COMMENTS}

Checklist Item \#6 - A firefighting restriction in the pre-incident fire plan restricts water around the reactor and computer room during fire fighting activities. This restriction is not being driven by criticality prevention therefore no change to the pre-incident fire plan is necessary

Checklist Item\#8

TREAT-MI-3330A - Annual calibration of the criticality alarm system is documented in the Work Order package 00149178 on November 16, 2010

TREAT-MI-3330B - Monthly calibration of the criticality alarm system is documented in the Work Order package 00161536 on August 8,2011

TREAT-MI-3330C - Quarterly calibration of the criticality alarm system is documented in the Work Order package 00159981 on July 18,2011

Summarize the changes that have been made to the facility, equipment and/or procedures since the last CCA inspection. Added Zone 11 (area outside 720 inside perimeter fence).

What are the current activities in the CCA? Describe: (refer to item \#9 from page 1)

Static fissionable material storage and Homeland security training.

$凶$ None

As documented in ICAMS system per LWP-13840

As documented eisewhere. Reference:

(Response Due Date)

September 13,2011


Date $\quad$ August 23, 2011

CCA(s): FMF

CSO C. S. Brower (or representative)
Inspector: J. T. Taylor

Building: MFC/ANL-W-704

Organization Name: Operations/Fuel Manufacturing

\section{INSPECTION PURPOSE}

Criticality Safety Engineening inspections of CCAs are perfommed to determine compliance with applicable requirements and to ensure that process conditions have not changed that would affect the Criticality Safety Evaluations (CSEs).

\section{FACILITY STATUS, SUMMARIZE CHECKLIST ACTIVITIES}

Record additional information and comments on page 2. Notify facility management of any imminent safety hazards

N/A YES NO

$\triangle \square$ 1. is CCA information listed correctly on the CCA master list? (Access the master list via https://nucleus .inl.gov/portal/server, pt?open=512\&objlD=369\&mode=2)

Master list date: $\quad 09 / 19 / 2011$

$\triangle \square$ 2. Are the boundaries identified and consistent with CCA information on file with Criticality Safety Engineering?

$\triangle \square$ 3. Is the most current and applicable governing criticality safety document in use at the time of this inspection of the CCA? List applicable documents (e.g., DSA, CHCS, LST, or CSE).

$\underline{\text { LST-386 }}$

$\square \square$ 4. If the CCA is posted, is the CCA posted correctly?

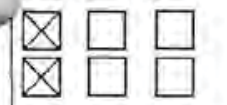

a) Is the CSO identified on posting(s) and, if applicable, Alternate?

b) Correct mass limit identified (applies to Mass CCAs only): $\leq 350 \mathrm{~g} \bigotimes$ or $\leq 250 \mathrm{~g}$ limit $\square$

5. How is inventory of fissionable material items maintained? LANMAS Total $(g)$ :

6. If there is a criticality control that affects emergency response, has the CSO reviewed the pre-incident plan? (on file with the INL Fire Department) $\triangle$ Yes $\square$ No $\quad$ Reference \# Pre Incident Plan for ANL-W-704

7. Were fissionable materials visibly labeled where practical?

8. Does the CCA have a Criticality Alarm System?

a) Are calibrations and testing current? References:

FMF-MITA-701B (7/20/11)

b) Are detectors free from any obstruction(s) that could impair criticality accident detection?

9. Are activities within facility, equipment, or procedures enveloped by the current and approved criticality safety documents (for example, DSAs, CSEs, applicable approval letter, and/or CHCS/LST of criticality controls) (Notify Facility management immediately if there is a safety concern) : (Describe on page 2)

$\square \square$ 10. Were observed in-progress activities in compliance with criticality safety limits? Describe details on page 2 if applicable. (Notify facility management immediately if there is a safety concern.)

邓 $\square$ 11. Was satisfactory progress made on action items noted during previous inspections? Summarize items and progress on page 2 if applicable.

X 12. Was the facility free from observable criticality safety problems, other than those described above? Describe items on page 2 if applicable. (Notify facility management immediately if there is a safety concern.) 


\section{ADDITIONAL INFORMATION AND COMMENTS}

The next revision of LST-386 needs to address "no liquid" in approved storage and identify the special reflectors.

Summarize the changes that have been made to the facility, equipment and/or procedures since the last CCA inspection -Installation of the SNM glovebox.

-Receipt of numerous $7 \mathrm{~A}$ drums with uranium clamshells. 45 clamshells have been processed.

What are the current activities in the CCA? Describe: (refer to item \#9 from page 1)

-SNM glovebox is in final stages of installation. LST-386 has been revised to allow work in glovebox.

-Vault CSI at time of inspection was 60

None

As documented in ICAMS system per LWP-13840

As documented elsewhere. Reference: 
Date: September 15, 2011

CCA(s): Lab Room 115

CSO: G. L. Seal (alternate)

(or representative)
Inspector: A. B. Hoffman/J. T. Taylor

Building: IRC-638

Organization Name: Reactor Physics Analysis and Design

\section{INSPECTION PURPOSE}

Criticality Safety Engineering inspections of CCAs are performed to detemine compliance with applicable requirements and to ensure that process conditions have not changed that would affect the Criticality Safety Evaluations (CSES).

\section{FACILITY STATUS, SUMMARIZE CHECKLIST ACTIVITIES}

Record additional information and comments on page 2. Notify facility management of any imminent safety hazards

N/A YES NO

Х

1. Is CCA information listed correctly on the CCA master list? (Access the masler list via https: //nucleus inl.gov/portal/server. pt?open=512\&objlD=369\&mode=2)

Master list date: $\quad 09 / 142011$ (minor change - L. D. Smith has been changed to S. Lindberg)

$\times$

2. Are the boundaries identified and consistent with CCA information on file with Criticality Safety Engineering?

3. Is the most current and applicable governing criticality safety document in use at the time of this inspection of the CCA? List applicable documents (e.g., DSA, CHCS, LST, or GSE).

LWP-18003, "Establishing, Operating, and Deleting CCAs"

4. If the CCA is posted, is the CCA posted correctly?

a) Is the CSO identified on posting(s) and, if applicable, Alternate?

b) Correct mass limit identified (applies to Mass CCAs only): $\leq 350 \mathrm{~g} \bigotimes$ or $\leq 250 \mathrm{~g}$ limit

5. How is inventory of fissionable material items maintained? Form 431.06 approved database

Total(g): 295.27

6. If there is a criticality control that affects emergency response, has the CSO reviewed the pre-incident plan? (on file with the INL Fire Department) $\square$ Yes $\otimes$ No Reference \#:

7. Were fissionable materials visibly labeled where practical? locked in cabinel

8. Does the CCA have a Criticality Alarm System?

a) Are calibrations and testing current? References:

b) Are detectors free from any obstruction(s) that could impair criticality accident detection?

9. Are activities within facility, equipment, or procedures enveloped by the current and approved criticality safety documents (for example, DSAs, CSEs, applicable approval letter, and/or CHCS/LST of criticality controls) (Notify Facility management immediateiy if there is a safety concern) : (Describe on page 2)

1351-07-STC, "Ultrasonic Testing for Fuel Development in IF-638"

10. Were observed in-progress activities in compliance with criticality safety limits? Describe details on page 2 if applicable. (Notify facility management immediately if there is a safety concern.)

11. Was satisfactory progress made on action items noted during previous inspections? Summarize items and progress on page 2 if applicable.

12. Was the facility free from observable criticality safety problems, other than those described above? Describe items on page 2 if applicable. (Notify facility management immediately if there is a safety concern.) 
Summarize the changes that have been made to the facility, equipment and/or procedures since the last CCA inspection No changes to the facility.

What are the current activities in the CCA? Describe: (refer to item \#9 from page 1)

NA

$\triangle$ None

As documented in ICAMS system per LWP-13840

As documented elsewhere. Reference.

\begin{tabular}{|l|l|l|l}
\hline Report Date & Assessor(s) & Inspeclion Record No. \\
September 15,2011 & A. B. Hoffman/J. T. Taylor & CSI11118
\end{tabular}




\section{CCA00404 \\ INVENTORY RECORD}

Page 1 of 2

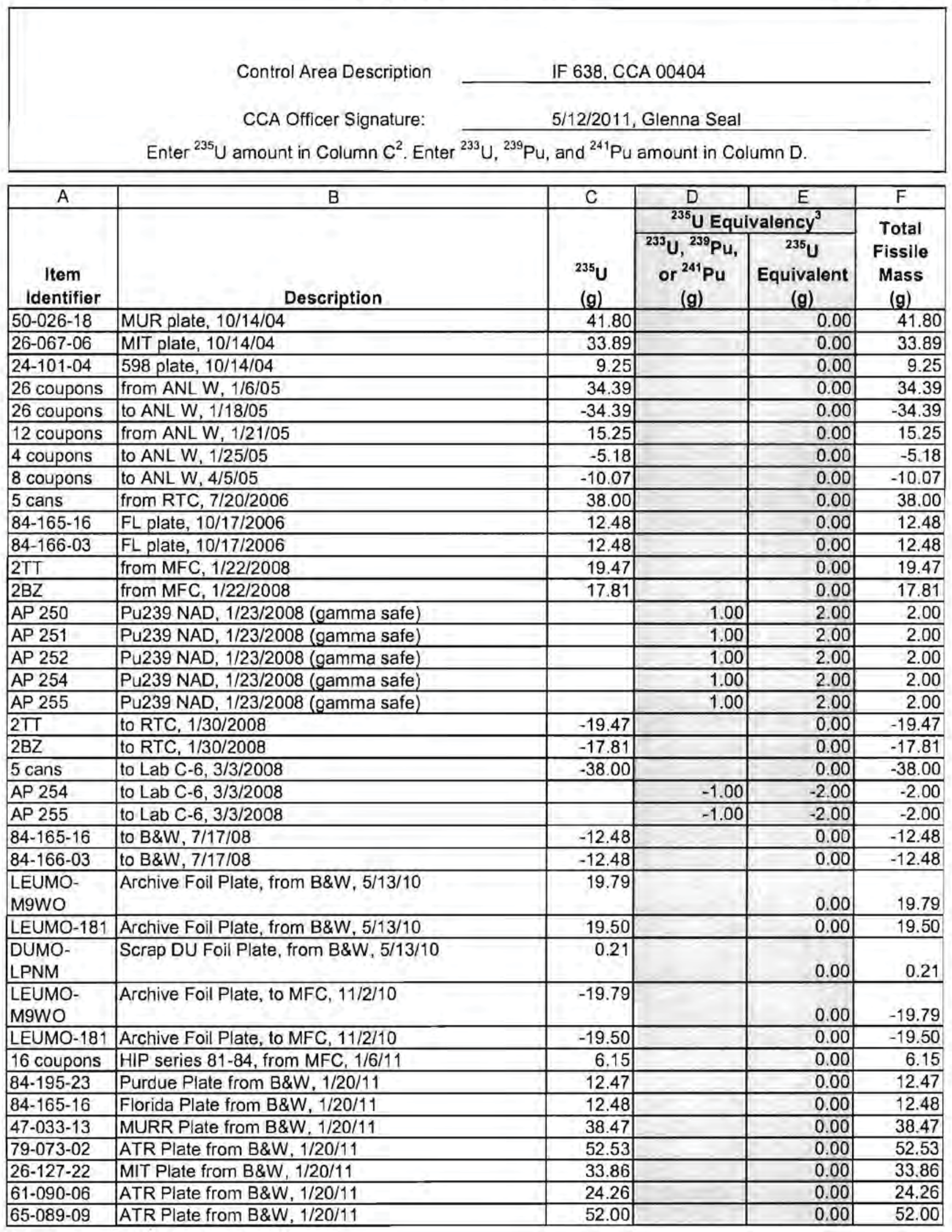




\section{CCA00404 \\ INVENTORY RECORD}

Page 2 of 2

\begin{tabular}{|c|c|c|c|c|c|}
\hline A & B & C & D & $E$ & $\mathrm{~F}$ \\
\hline & & & ${ }^{235} \mathrm{U}$ Equ & valency $^{3}$ & Total \\
\hline $\begin{array}{c}\text { Item } \\
\text { Identifier }\end{array}$ & Description & $\begin{array}{l}{ }^{235} U \\
(\mathrm{~g})\end{array}$ & $\begin{array}{c}{ }^{233} \mathrm{U}_{,}{ }^{239} \mathrm{Pu} \text {, } \\
\text { or }{ }^{241} \mathrm{Pu} \\
\text { (g) }\end{array}$ & $\begin{array}{c}{ }^{235} \mathrm{U} \\
\text { Equivalent } \\
\text { (g) }\end{array}$ & $\begin{array}{c}\text { Fissile } \\
\text { Mass } \\
\text { (g) }\end{array}$ \\
\hline $50-026-18$ & MUR plate to Lab C- $6,5 / 4 / 2011$ & -41.80 & & & -41.80 \\
\hline $26-067-06$ & MIT plate to Lab C-6, 5/4/2011 & -33.89 & & & -33.89 \\
\hline $24-101-04$ & 598 plate to Lab C- $6,5 / 4 / 2011$ & -9.25 & & & -9.25 \\
\hline $\begin{array}{l}\text { LEUMO- } \\
\text { RIX4 }\end{array}$ & LEU U-Moly Archive Plate from B\&W, 5/12/2011 & 56.83 & & & 56.83 \\
\hline & & & & & 0.00 \\
\hline & & & & & 0.00 \\
\hline & & & & & 0.00 \\
\hline & & & & 0.00 & 0.00 \\
\hline & & & & Total: & 295.27 \\
\hline
\end{tabular}


Date: September 15, 2011

CCA(s): Lab C-6

CSO: G. L. Seal (alternate) (or representative)
Inspector: A. B. Hoffman/J. T. Taylor

Building: IRC/IF-603

Organization Name: Reactor Phyiscs Analysis and Design

\section{INSPECTION PURPOSE}

Criticality Safety Engineering inspections of CCAs are performed to determine compliance with applicable requirements and to ensure that process conditions have not changed that would affect the Criticality Safety Evaluations (CSES).

FACILITY STATUS, SUMMARIZE CHECKLIST ACTIVITIES

Record additional information and comments on page 2. Nolify facility management of any imminent safety hazards

N/A YES NO

1. Is CCA information listed correctly on the CCA master list? (Access the master list via https: $/ /$ nucleus.inl.gov/portal/server.pt?open $=512 \&$ objlD $=369 \&$ mode $=2$ )

Master list date: $\quad 09 / 14 / 11$ (minor change - L. D. Smith has been changed to: S. Lindberg)

2. Are the boundaries identified and consistent with CCA information on file with Criticality Safety Engineering? Lab C-6 only

$\triangle \square$ 3. Is the most current and applicable governing criticality safely document in use at the time of this inspection of the CCA? List applicable documents (e.g., DSA, CHCS, LST, or CSE).

LWP-18003, "Establishing. Operating, and Delefing CCAs"

4. If the CCA is posted, is the CCA posted correctly?

a) Is the CSO identified on posting(s) and, if applicable. Alternate?

b) Correct mass limit identified (applies to Mass CCAs only): $\leq 350 \mathrm{~g} \bigotimes$ or $\leq 250 \mathrm{~g}$ limit

5. How is inventory of fissionable material items maintained? Form 431.03

$\operatorname{Total}(\mathrm{g}): \underline{126.94 \mathrm{~g}}$

6. If there is a criticality control that affects emergency response, has the CSO reviewed the pre-incident plan? (on file with the INL Fire Department) $\square$ Yes $\square$ No Reference \#:

7. Were fissionable materials visibly labeled where practical? 5 safeguards cans and 3 plates

8. Does the CCA have a Criticality Alarm System?

a) Are calibrations and testing current? References:

b) Are detectors free from any obstruction(s) that could impair criticality accident detection?

9. Are activities within facility, equipment, or procedures enveioped by the current and approved criticality safety documents (for example, DSAs, CSEs, applicable approval letter, and/or CHCS/LST of criticality controls) (Notify Facility management immediately if there is a safety concern) : (Describe on page 2)

1338-07-IRC "Radiation Instrumentation and Measurement R\&D -IRC-C6" _ SEE BACK

10. Were observed in-progress activities in compliance with criticality safety limits? Describe details on page 2 if applicable. (Notify facility management immediately if there is a safety concern.)

11. Was satisfactory progress made on action items noted during previous inspections? Summarize items and progress on page 2 if applicable

12. Was the facility free from observable criticality safety problems, other than those described above? Describe items on page 2 if applicable. (Notify facility management immediately if there is a safety concern.) 
Rev. 09

\section{ADDITIONAL INFORMATION AND COMMENTS}

9. CSO, Glenna Seal said the LI for this facility will be revised to reflect the fissionable limit of 350 grams instead of $250 \mathrm{grams}$ NOTE: The 250 gram limit was put in place in the document by the old facility manager)

Summarize the changes that have been made to the facility, equipment and/or procedures since the last CCA inspection. No changes to the facility.

What are the current activities in the CCA? Describe: (refer to item \#9 from page 1)

NA

$凶$ None

As documented in ICAMS system per LWP-13840

As documented elsewhere. Reference 


\section{CCA00404 \\ INVENTORY RECORD}

Page 1 of 1

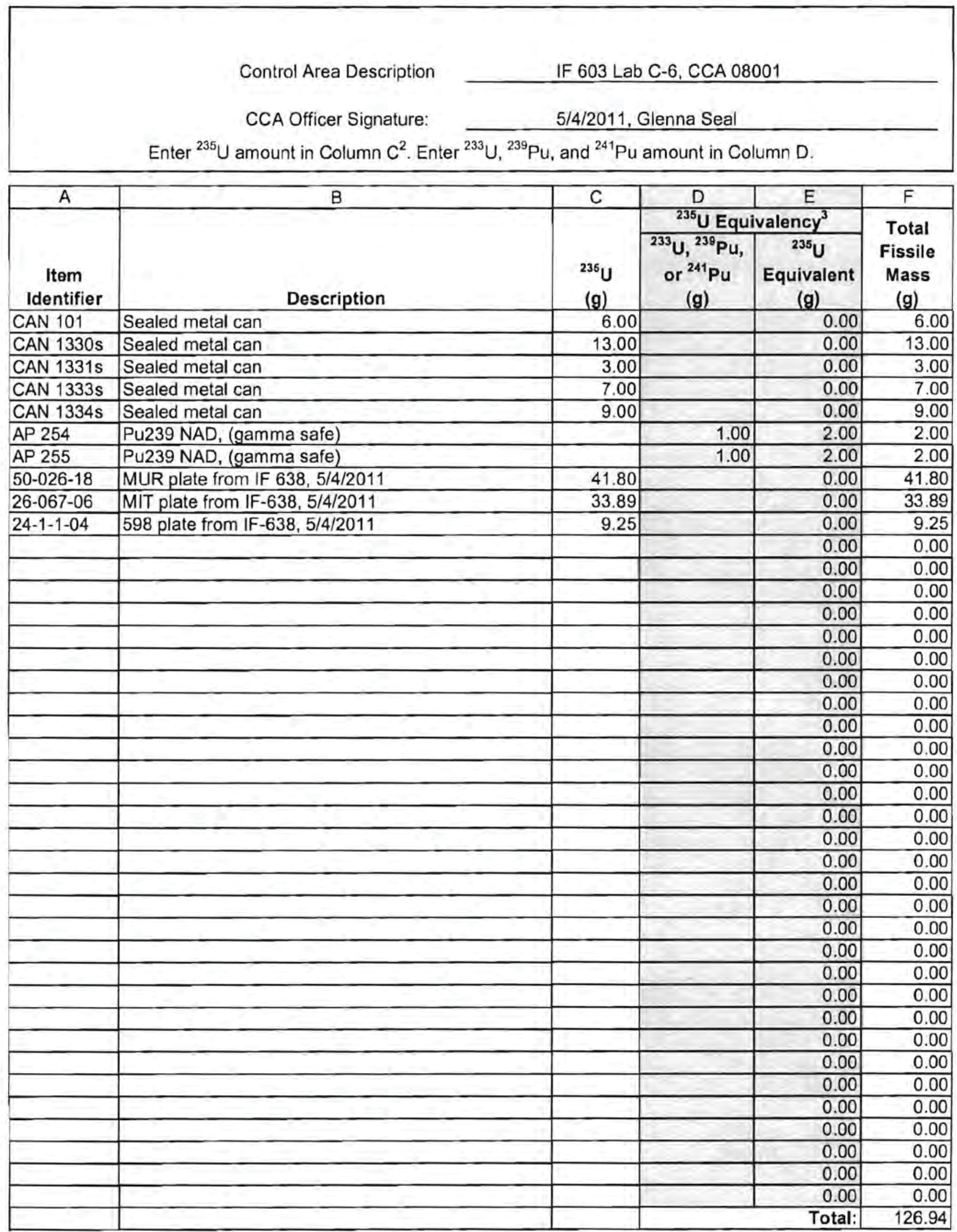


431.03 CRITICALITY CONTROL AREA (CCA) INSPECTION CHECKLIST

Rev. 09

Page 1 of 3

Date: $\quad$ August 17, 2011

CCA(s): CITRC

CSO: D. R. Norman (or representative)
Inspector: J. T. Taylor/A. B. Hoffman

Building: $\underline{622}$

Organization Name: Sensor Technologies

INSPECTION PURPOSE

Criticality Safety Engineening inspections of CCAs are performed to determine compliance with applicable requirements and to ensure that process conditions have not changed that would affect the Criticality Safety Evaluations (CSEs).

FACILITY STATUS, SUMMARIZE CHECKLIST ACTIVITIES

Record additional information and comments on page 2. Notify facility management of any imminent safety hazards

NIA YES NO

1. Is CCA information listed correctly on the CCA master list? (Access the master list via https: //nucleus. inl.gov/portal/server. pt?open=512\&objlD=369\&mode=2)

Master list date: $\quad 05 / 02 / 2011$ replaced D. G. Blatter as Line Manager per LWP-18005

$\triangle \square$ 2. Are the boundaries identified and consistent with CCA information on file with Criticality Safety Engineering?

Х 3. Is the most current and applicable governing criticality safely document in use at the time of this inspection of the CCA? List applicable documents (e.g., DSA, CHCS, LST, or CSE).

4. If the CCA is posted, is the CCA posted correctly?

a) Is the CSO identified on posting(s) and, if applicable, Alternate?

b) Correct mass limit identified (applies to Mass CCAs only): $\leq 350 \mathrm{~g} \square$ or $\leq 250 \mathrm{~g}$ limit $\square$

5. How is inventory of fissionable material items maintained? see attached inventory form

Total(g): 0

6. If there is a criticality control that affects emergency response, has the CSO reviewed the pre-incident plan? (on file with the INL Fire Department) $\square$ Yes $\square$ No Reference \#:

$\bigotimes \square \square 7$. Were fissionable materials visibly labeled where practical?

a) Are calibrations and testing current? References:

b) Are detectors free from any obstruction(s) that could impair criticality accident detection?

9. Are activities within facility, equipment, or procedures enveloped by the current and approved criticality safety documents (for example, DSAs, CSEs, applicable approval letter, and/or CHCS/LST of criticality controls) (Notify Facility management immediately if there is a safety concern) : (Describe on page 2)

$\square$ 10. Were observed in-progress activities in compliance with criticality safety limits? Describe details on page 2 if applicable. (Notify facility management immediately if there is a safety concern.)

11. Was satisfactory progress made on action items noted during previous inspections? Summarize items and progress on page 2 if applicable.

12. Was the facility free from observable criticality safety problems, other than those described above? Describe items on page 2 if applicable. (Notify facility management immediately if there is a safety concern.) 


\section{ADDITIONAL INFORMATION AND COMMENTS}

No material is being stored currently at this CCA location.

Summarize the changes that have been made to the facility, equipment and/or procedures since the last CCA inspection NA

What are the current activities in the CCA? Describe: (refer to item \#9 from page 1)

NA

$\triangle$ None

As documented in ICAMS system per LWP-13840

As documented elsewhere. Reference:

\begin{tabular}{|l|l|l|l|}
\hline Report Date & Assessor(s) & & \\
August 18,2011 & J.T. Taylor/A. B. Hoffmar & Inspection Record No.
\end{tabular}


Idaho National Laboratory

\begin{tabular}{|c|c|c|}
\hline $\begin{array}{c}\text { PROCEDURE CRITICALITY CONTROL } \\
\text { AREAS AT CITRC }\end{array}$ & $\begin{array}{ll}\text { Identifier: } & \text { LI-399 } \\
\text { Revision: } & 0 \\
\text { Effective Date: } & 03 / 19 / 09\end{array}$ & Page: 7 of 11 \\
\hline
\end{tabular}

\section{Appendix A - CITRC Criticality Control Areas Inventory Record}

Criticality Safety Officer Signature:
Transfer Verification Signature:

\begin{tabular}{|l|l|l|l|l|}
\hline \multicolumn{3}{|c|}{ FACIITY-IRTTC (PBF-609,622,623, and 641) Inventory } \\
Total U-235 Equivalent Mass must be less than 700 grams & $\begin{array}{l}\text { U-235 } \\
\text { mass (g) }\end{array}$ & $\begin{array}{l}\text { U-233, Pu-239, } \\
\text { Pu-241 mass (g) }\end{array}$ & $\begin{array}{l}\text { U-235 } \\
\text { Equivalent mass }\end{array}$ \\
\hline Item Number & Description & & & \\
\hline & & & & \\
\hline & & & & \\
\hline & & & & \\
\hline & & & Total mass (g) & \\
\hline $\begin{array}{l}\text { * NOTE : For U-233, Pu-239, and Pu-24I the mass must be multiplied } \\
\text { by 2 to obtain the U-235 Equivalency mass }\end{array}$
\end{tabular}

\begin{tabular}{|c|c|c|c|c|}
\hline Total U-235 Equivalent Mass & $\begin{array}{l}\text { FACILITY-SPF (PF } \\
\text { must be less than } 700 \text { gra }\end{array}$ & is -612) Invento & & $\therefore$ \\
\hline Item Number & Description & $\begin{array}{l}\text { U-235 } \\
\text { mass }(\mathrm{g})\end{array}$ & $\begin{array}{l}\text { "U-233, Pu-239, } \\
\text { Pu-241 mass (g) }\end{array}$ & $\begin{array}{l}\text { U-235 } \\
\text { Equivalent mass }\end{array}$ \\
\hline $\begin{array}{l}225-20-08454-61039 \\
225-20-8454-60930\end{array}$ & $\begin{array}{l}\text { Heuplata } \\
\text { Hea plaxe }\end{array}$ & 268.66 & $=$ & $\begin{array}{l}268: 66 \\
268 \cdot 32\end{array}$ \\
\hline & & & & \\
\hline & & & & \\
\hline & & & & \\
\hline $\begin{array}{l}\text { *NOTE : For U-233, Pu- } 239 \text {, a } \\
\text { by } 2 \text { to obtain the U-235 Equiva }\end{array}$ & $\begin{array}{l}\text { d Pu- } 24 \mathrm{I} \text { the mass must } \\
\text { ency mass }\end{array}$ & multiplied & Total mass $(\mathrm{g})$ & 536.98 \\
\hline
\end{tabular}

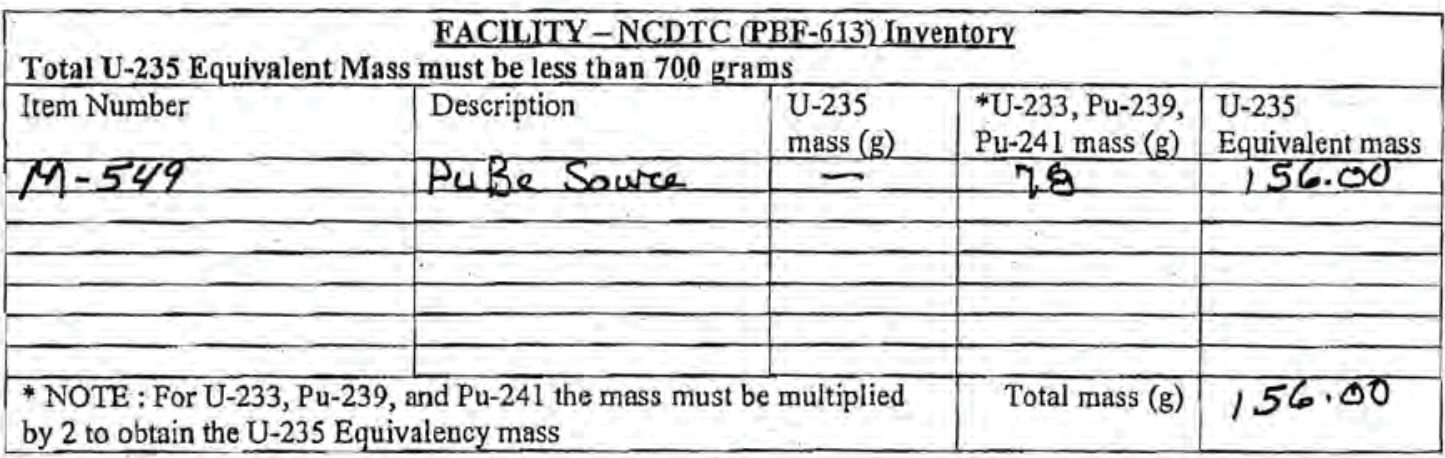

\begin{tabular}{|c|c|c|c|c|}
\hline Total U-235 Equivalent Mass & $\begin{array}{r}\text { Transfer Ir } \\
\text { must be less than } 350 \mathrm{gr}\end{array}$ & $\frac{\text { ventory }}{\text { ms too and } f}$ & & \\
\hline Item Number & From Transfer & $\begin{array}{l}\mathrm{U}-235 \\
\operatorname{mass}(\mathrm{g})\end{array}$ & $\begin{array}{l}{ }^{*} \mathrm{U}-233, \mathrm{Pu}-239, \\
\text { Pu-24I mass }(\mathrm{g})\end{array}$ & $\begin{array}{l}\text { U-235 } \\
\text { Equivalent mass }\end{array}$ \\
\hline $\begin{array}{l}\text { NOTE : For U-233, Pu-239, } \\
\text { by } 2 \text { to obtain the U-235 Equiv }\end{array}$ & $\begin{array}{l}\mathrm{d} \text { Pu- } 241 \text { the mass must } \\
\text { ency mass }\end{array}$ & multiplied & Total mass $(\mathrm{g})$ & \\
\hline
\end{tabular}


Date: September 14, 2011

CCA(s): EML

CSO: J.C. Merrill

(or representative)
Inspector: A. B. Hoffman

Building: MFC/ANL-W 1702

Organization Name: FUEL MANUFACTURING

\section{INSPECTION PURPOSE}

Criticality Safety Engineering inspections of CCAs are performed to determine compliance with applicable requirements and to ensure that process conditions have not changed that would affect the Cnticality Safety Evaluations (CSES).

\section{FACILITY STATUS, SUMMARIZE CHECKLIST ACTIVITIES}

Record additional information and comments on page 2. Notify facility management of any imminent safety hazards

N/A YES NO

$\triangle \square$ 1. Is CCA information listed correctly on the CCA master list? (Access the master list via https://nucleus ini.gov/portal/server.pt?open=512\&objlD=369\&mode=2)

Master list date: $\quad 8 / 31 / 11$

2. Are the boundaries identified and consistent with CCA information on file with Criticality Safety Engineering?

3. Is the most current and applicable governing criticality safety document in use at the time of this inspection of the CCA? List applicable documents (e.g., DSA, CHCS, LST, or CSE).

INL/NT-10-18996, "CSE for 700 Gram MFE Criticality Control Areas (CCAs)"

$\triangle \square \square$ 4. If the CCA is posted, is the CCA posted correcily?

a) Is the CSO identified on posting(s) and, if applicable. Alternate?

b) Correct mass limit identified (applies to Mass CCAs only): $\leq 350 \mathrm{~g} \square$ or $\leq 250 \mathrm{~g}$ limit $\square$

5. How is inventory of fissionable material items maintained? See Back

Total $(g): 484.98$

6. If there is a criticality control that affects emergency response, has the CSO reviewed the pre-incident plan? (on file with the INL Fire Department) $\square$ Yes $\square$ No Reference \#

$\bigotimes \square \square 7$.

区

区

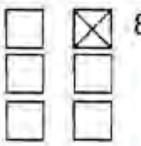

(Went

Were fissionable materials visibly labeled where practical?

No fissionable materials were observed at the time of inpection.

8. Does the CCA have a Criticality Alarm System?

a) Are calibrations and testing current? References:

b) Are detectors free from any obstruction(s) that could impair criticality accident detection?

9. Are activities within facility, equipment, or procedures enveloped by the current and approved criticality safety documents (for example, DSAs, CSEs, applicable approval letter, and/or CHCS/LST of criticality controls) (Notify Facility management immediately if there is a safety concern) : (Describe on page 2)

INL/INT-10-18996, "CSE for 700 Gram MFE CCAS", SD-37.1.4

10. Were observed in-progress activities in compliance with criticality safety limits? Describe details on page 2 if applicable. (Notify facility management immediately if there is a safety concern.)

11. Was satisfactory progress made on action items noted during previous inspections? Summarize items and progress on page 2 if applicable.

12. Was the facility free from observable criticality safety problems, other than those described above? Describe items on page 2 if applicable. (Notify facility management immediately if there is a safety concern.) 


\section{ADDITIONAL INFORMATION AND COMMENTS}

5. CSO J. Merrill is maintaining the inventory in a computer database, A new database has been developed recently for calculating fazard Categorization, etc.and is still in the QA review and approval process It is anticipated that the new database will be used at EML when the implementation process is complete.

10. Tom O'Holleran was bagging up material (typically $U, \mathrm{Pu}$, and Am samples due to Hazard Categorization level restrictions) out of a glovebox in EML at the time of the CCA inspection.

Summarize the changes that have been made to the facility, equipment and/or procedures since the last CCA inspection.

A new Glove Box has already been erected outside of the lab and is covered in plastic. There are plans for construction of a new addition to the facility contingent upon more funding.

What are the current activities in the CCA? Describe: (refer to item \#9 from page 1)

Most of the material from HFEF Room 125 Mass Limit CCA has been transferred into the EML.

None

As documented in ICAMS system per LWP-13840

As documented elsewhere. Reference:

(Response Due Date)

\begin{tabular}{l|lll}
\hline Report Date & Assessor(s) & Inspection Record No. \\
September 14,2011 & A. B. Hoffman & CSl11121
\end{tabular}


This page intentionally blank 


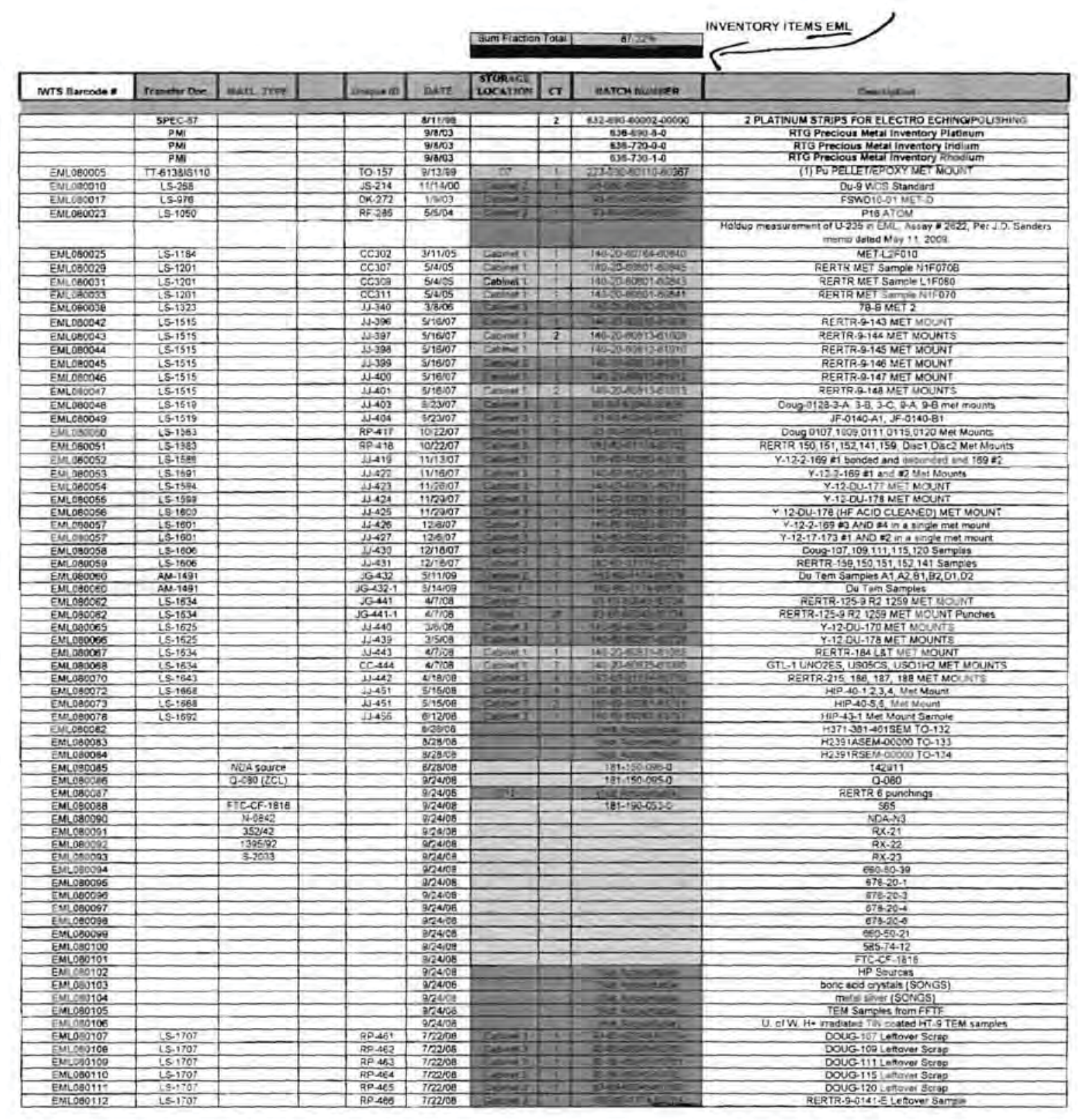

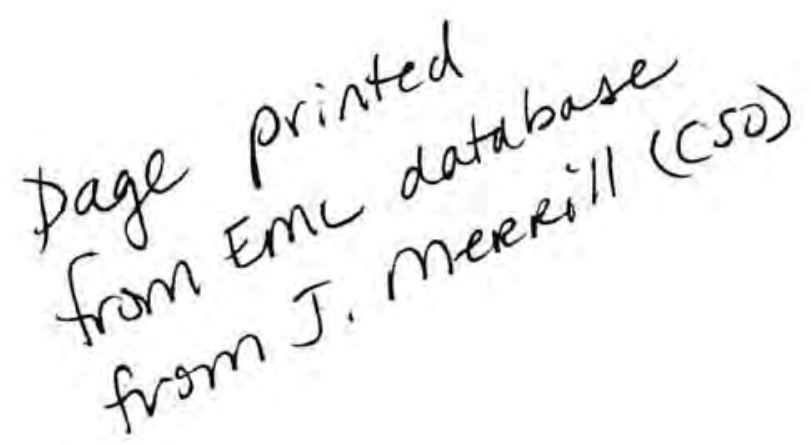


This page intentionally blank 
Date: September 14, 2011

CCA(s) ORSA

CSO: J. Blankenship (or representative) inspector: L. R. Flatten

Building: MFC/ANLW-797

Organization Name: Hot Cell Services

\section{INSPECTION PURPOSE}

Griticality Safety Engineering inspections of CCAs are performed to determine compliance with applicable requirements and lo ensure thal process conditions have not changed that would affect the Criticality Safety Evaluations (CSES).

FACILITY STATUS, SUMMARIZE CHECKLIST ACTIVITIES

Record additional information and comments on page 2. Notify facility management of any imminent safety hazards

N/A YES NO

$\triangle \square$ 1. Is CCA information listed correctly on the CCA master list? (Access the master list via https://nucleus.inl.goviportal/server.pt?open=512\&objlD=369\&mode=2)

Master list date: $\quad 8 / 31 / 2011$

Х 2. Are the boundaries identified and consistent with CCA information on file with Criticality Safety Engineering?

$\bigotimes \square$ 3. Is the most current and applicable governing criticality safety document in use at the time of this inspection of the CCA? List applicable documents (e.g. DSA, CHCS, LST, or CSE). INL/INT-09-15995/TSD-OI-004/FRM-323

$\bigotimes \square \square$ 4. If the CCA is posted, is the CCA posted correctly?

a) Is the CSO identified on posting(s) and, if applicable. Alternate?

b) Correct mass limit identified (applies to Mass CCAs only): $\leq 350 \mathrm{~g} \square$ or $\leqslant 250 \mathrm{~g}$ limit $\square$

5. How is inventory of fissionable material items maintained? IWTS Total(g): $325 \mathrm{~g}$

6. If there is a criticality control that affects emergency response, has the CSO reviewed the pre-incident plan? (on file with the INL Fire Department) $\square$ Yes $\square$ No Reference H:

7. Were fissionable materials visibly labeled where practical?

$\triangle$ 8. Does the CCA have a Criticality Alarm System?

b) Are detectors free from any obstruction(s) that could impair criticality accident detection?

$\triangle \square$ 9. Are activities within facility, equipment, or procedures enveloped by the current and approved criticality safety documents (for example, DSAs, CSEs, applicable approval letter, and/or CHCSILST of criticality controls) (Notify Facility management immediately if there is a safety concern): (Describe on page 2)

$\bigotimes \square \square$ 10. Were observed in-progress activities in compliance with criticality safety limils? Describe details on page 2 if applicable. (Notify facility management immediately if there is a safety concern.)

11. Was satisfactory progress made on action items noted during previous inspections? Summarize items and progress on page 2 if applicable.

$\bigotimes \square$ 12. Was the facility free from observable criticality safety problems, other than those described above? Describe ltems on page 2 if applicable. (Notify facility management immediately if there is a safely concern.) 


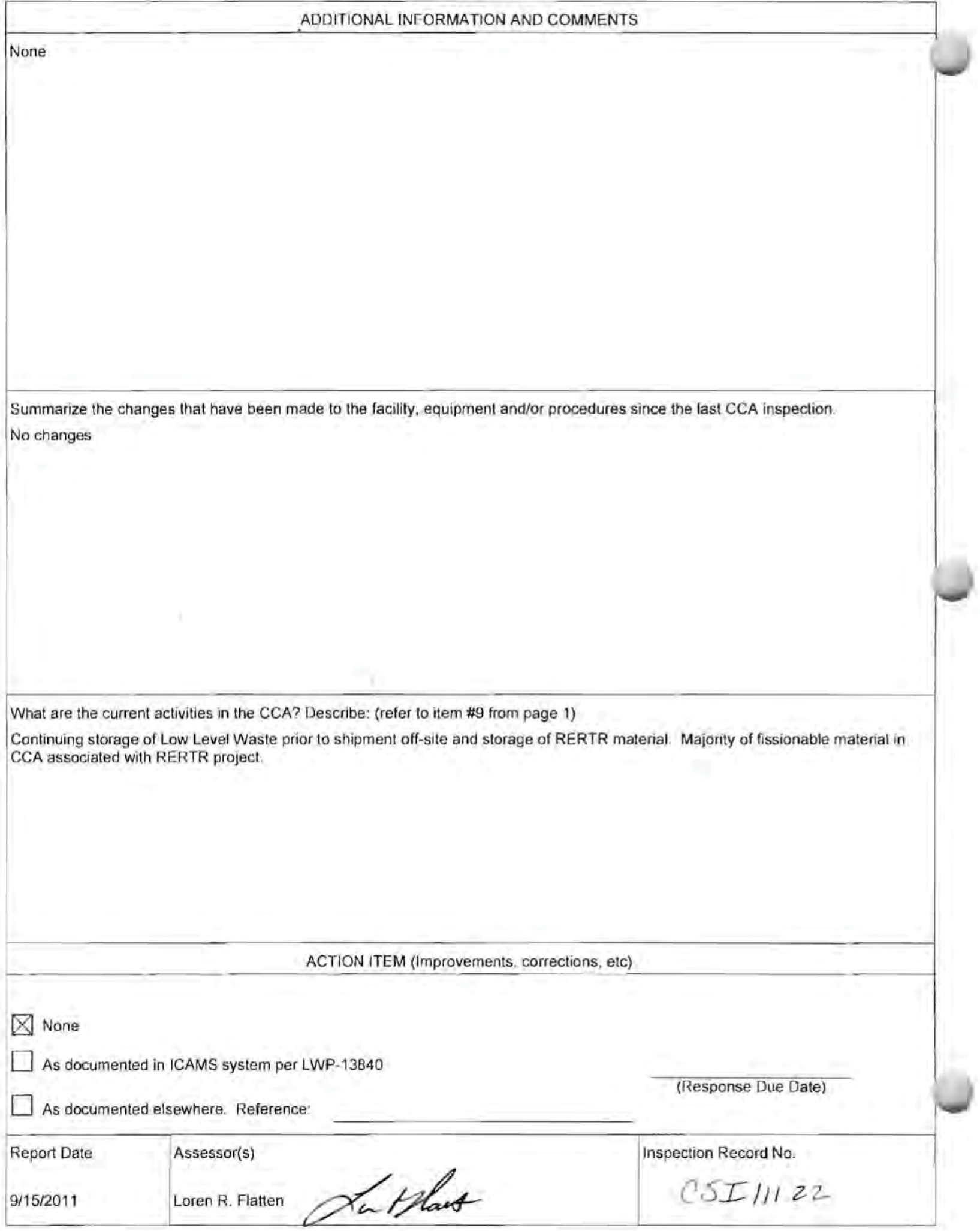




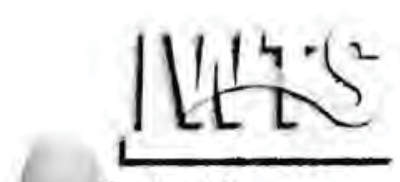

Inventory Limits - Unit Level

BEA : MFC : ANL BIdg 797 Outside Radioactive Storage Area (ORSA)

Evaluated On: 12-Sep-2011

\begin{tabular}{|l|l|c|c|c|c|c|c|}
\hline & $\begin{array}{c}\text { Location } \\
\text { Type }\end{array}$ & $\begin{array}{c}\text { Location } \\
\text { Abbr }\end{array}$ & $\begin{array}{c}\text { Inventory } \\
\text { Value }\end{array}$ & $\begin{array}{c}\text { Limit } \\
\text { Value }\end{array}$ & $\begin{array}{c}\text { Limit } \\
\text { Unit }\end{array}$ & $\begin{array}{c}\% \text { of } \\
\text { Limit }\end{array}$ & $\begin{array}{c}\text { Check } \\
\text { Status }\end{array}$ \\
\hline Cat 3 (no release fractions) Check UNIT & ANL797_ORS & $5.9129 E-02$ & $<=$ & $1.00 E+00$ & $\%$ & $5.91 E+00$ & \\
\hline
\end{tabular}

\begin{tabular}{|c|c|c|c|}
\hline Fissile Limit Gram Check (High Vol) UNIT & ANL797_ORS & $3.25 E+02<=$ & $7.00 E+02$ FGE \\
\hline
\end{tabular}




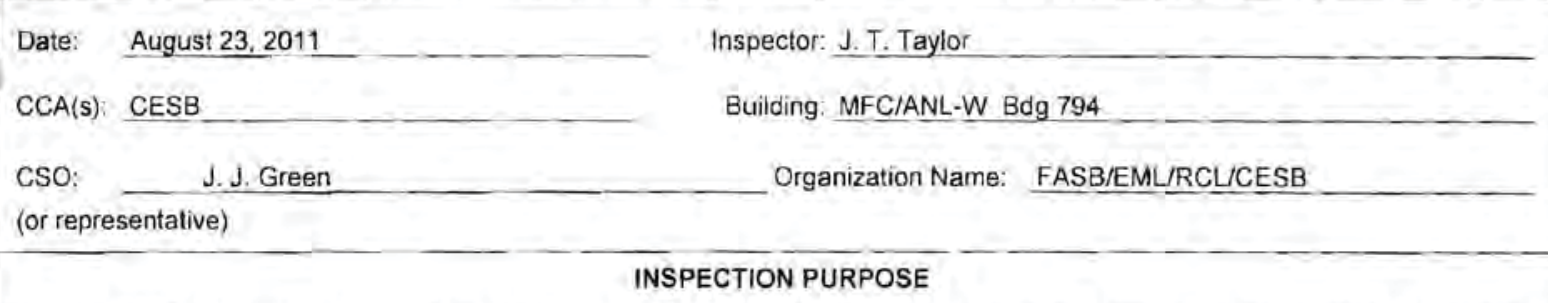

Criticality Safety Engineering inspections of CCAs are performed to determine compliance with applicable requirements and to ensure thal process conditions have not changed that would affect the Criticality Safety Evaluations (CSES)

FACILITY STATUS, SUMMARIZE CHECKLIST ACTIVITIES

Record additional information and comments on page 2. Notify facility management of any imminent safety hazards

N/A YES NO

$\triangle \square 1$. is CCA information listed correctly on the CCA master list? (Access the master list via https $/ /$ nucleus inl.gov/portal/server, pt?open $=512 \&$ objlD $=3698$ mode $=2$ )

Master list date:

$\triangle \square 2$ Are the boundaries identified and consistent with CCA information on file with Criticality Safety Engineering?

$\bigotimes \square$ 3. Is the most current and applicable governing criticality safety document in use at the time of this inspection of the CCA? List applicable documents (e.g., DSA, CHCS, LST, or CSE).

Currently operating with INLINT-09-15995, "Criticality Safety Controls for the ORSA and CESB CCAs"

4. If the CCA is posted, is the CCA posted correctly?

a) Is the CSO identified on posting(s) and, if applicable, Alternate?

b) Correct mass limit identified (applies to Mass CCAs only): $\leq 350 \mathrm{~g} \bigotimes$ or $\leq 250 \mathrm{~g} \mathrm{limit}$ -

5. How is inventory of fissionable material items maintained? approved electronic database inventory Total(g): 602.96 MFE

$\triangle \square \square$ 6. If there is a criticality control that affects emergency response, has the CSO reviewed the pre-incident plan? (on file with the INL Fire Department) $\square$ Yes $\square$ No Reference \#:

7. Were fissionable materiais visibly labeled where practical? The plates and coupons inspected were all labelled

8. Does the CCA have a Criticality Alarm System?

a) Are calibrations and testing current? References:

b) Are detectors free from any obstruction(s) that could impair criticality accident detection?

$\bigotimes \square$ 9. Are activities within facility, equipment, or procedures enveloped by the current and approved criticality safely documents (for example, DSAs, CSEs, applicable approval letter, and/or CHCS/LST of criticality controls) (Notify Facility management immediately if there is a safety concern) : (Describe on page 2) The inventory is less than $700 \mathrm{~g} U 235 \mathrm{MFE}$.

10. Were observed in-progress activities in compliance with criticality safety limits? Describe details on page 2 if applicable. (Notify facility management immediately if there is a safety concern.)

$\bigotimes \square \square$ 11. Was salisfactory progress made on action items noted during previous inspections? Summarize items and progress on page 2 if applicable.

$\triangle \square$ 12. Was the facility free Irom observable criticality safety probiems, other than those described above? Describe items on page 2 if applicable. (Notify facility management immediately if there is a safely concern.) 
Summarize the changes that have been mave to the faciuty, equipment and/or procedures since the last CCA inspection RERTR fuel program is in place in CESB.

What are the current activities in the CCA? Describe: (refer to item \#9 from page 1)

CESB will be downgraded to a less than Hazard Category 3 Nuclear facility. RERTR aclivities are taking place now in CESB. The CSE for FASB (INL/NTT-10-18996, Criticality Safety Evaluation for $700 \mathrm{Gram}$ Moderaled Fissionable Equivalent (MFE) Criticality Control Areas (CCA)", will be used at CESB to make implementation easier for S \& T and Operations.

\section{ACTION ITEM (Improvements, corrections, etc)}

None

$\square$ As documented in ICAMS system per LWP-13840

$\neg$ As documented elsewhere. Reference:

(Response Due Date)

\begin{tabular}{|l|l|l|l}
\hline Report Date & Assessor(s) & Inspection Record No
\end{tabular}




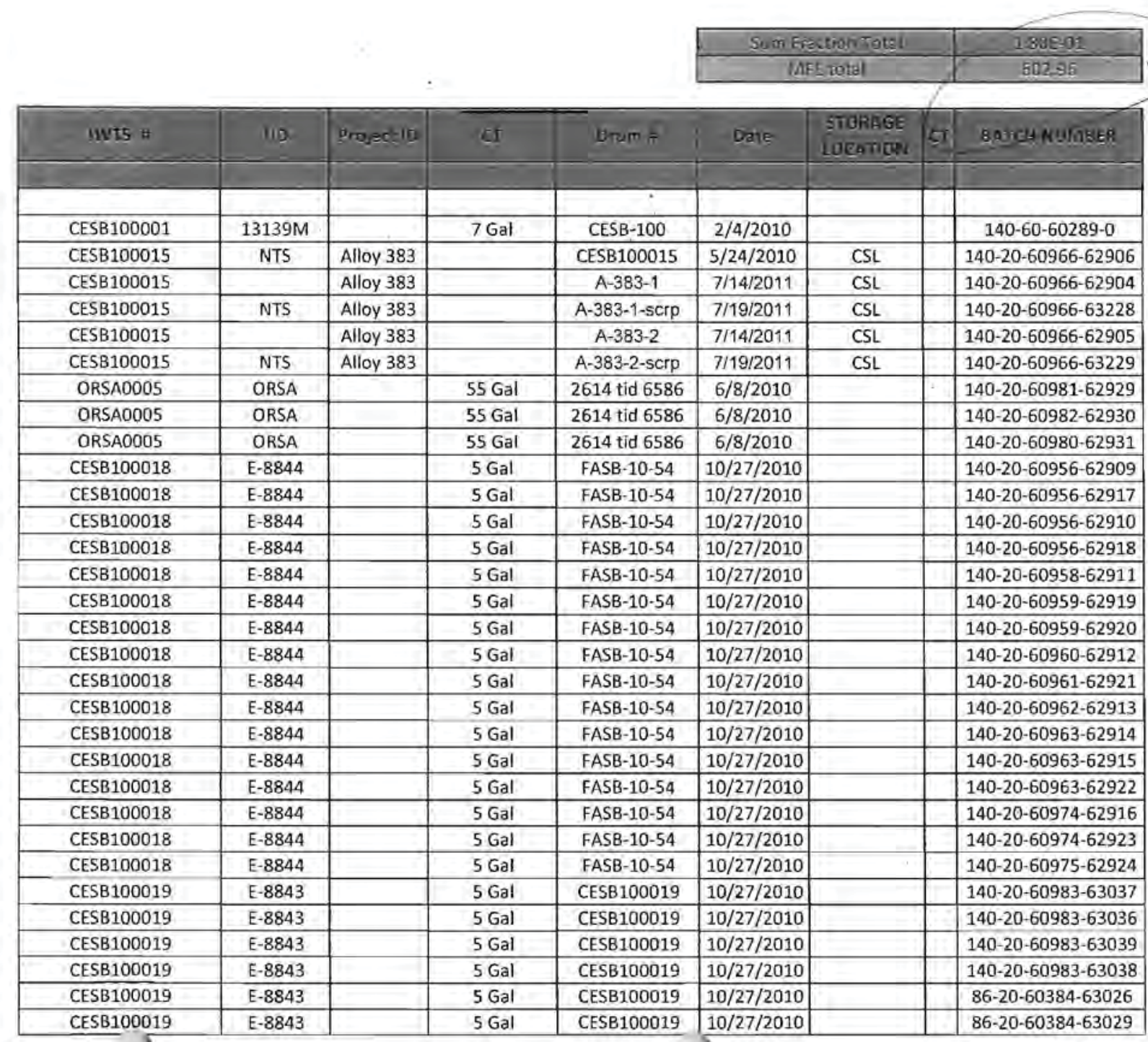

Pagel of C S B Aventory spread sheet 
Date. September 14, 2011

$\mathrm{CCA}(\mathrm{s}) \quad \underline{\mathrm{RCL}}$

CSO: J.C. Merrill

(or representative)
Inspector: A. B. Hoffman

Building MFC/ANL-W 1702

Organization Name: FUEL MANUFACTURING

\section{INSPECTION PURPOSE}

Criticality Safety Engineering inspections of CCAs are performed to detenmine compliance with applicable requirements and to ensure that process conditions have not changed that would affect the Criticality Safety Evalualions (CSES).

FACILITY STATUS, SUMMARIZE CHECKLIST ACTIVITIES

Record additional information and comments on page 2. Notify facility management of any imminent safety hazards

N/A YES NO

$\bigotimes \square 1 . \quad$ is CCA information listed correctly on the CCA master list? (Access the master list via https: $/ /$ nucleus . inl.gov/portal/server. pt?open $=5128$ objl $\mathrm{D}=369 \&$ mode $=2$ )

Master list date: $\quad 9 / 14 / 11$

$\triangle \square$ 2. Are the boundaries identified and consistent with CCA information on file with Criticality Safety Engineering?

$\triangle \square$ 3. Is the most current and applicable governing criticality safety document in use at the time of this inspection of the CCA? List applicable documents (e.g., DSA, CHCS, LST, or CSE). LWP-18003

4. If the CCA is posted, is the CCA posted correctly? See Back

a) Is the CSO identified on posting(s) and, if applicable, Alternale?

b) Correct mass limit identified (applies to Mass CCAs only): $\leq 350 \mathrm{~g} \square$ or $\leq 250 \mathrm{~g} \mathrm{limit} \square$

5. How is inventory of fissionable material items maintained? Database spreadsheet - attached Tolal(g): $60.670 \mathrm{MFE}$

6. If there is a criticality control that affects emergency response, has the CSO reviewed the pre-incident plan? (on file with the INL Fire Department) $\square$ Yes $\square$ No $\quad$ Reference\#:

$凶 \square \square 7$. Were fissionable materials visibly labeled where practical?

8. Does the CCA have a Criticality Alarm System?

a) Are calibrations and testing current? References:

b) Are detectors free from any obstruction(s) that could impair criticality accident detection?

9. Are activities within facilify, equipment, or procedures enveloped by the current and approved crilicality safety documents (for example, DSAs, CSES, applicable approval letter, and/or CHCS/LST of criticality controls) (Notify Facility management immediately if there is a safely concern): (Describe on page 2)

$\triangle \square \square$ 10. Were observed in-progress activities in compliance with criticality safety limits? Describe details on page 2 if applicable. (Notify facility management immediately if there is a safety concern.)

$\triangle \square \square$ 11. Was salisfactory progress made on action items noted during previous inspections? Summarize items and progress on page 2 if applicable.

$\bigotimes \square$ 12. Was the facility free from observable criticality safety problems, other than those described above? Describe items on page 2 if applicable. (Notify facility management immediately if there is a safety concern.) 
4. Access to the CCA was restricted due to construction so postings were not inspected, however new signs were given to CSO.

Summarize the changes that have been made to the facility, equipment and/or procedures since the last CCA inspection. Note: As recommended in last year's inspection, only one posting be used for the door where materials/shipments will be coming into or going out of the RCL instead of the current practice of posting all fire doors.

What are the current activities in the CCA? Describe: (refer to item \#9 from page 1)

$\triangle$ None

$\square$ As documented in ICAMS system per LWP-13840

As documented elsewhere. Reference

\begin{tabular}{|l|l|l}
\hline Report Date & Assessor(s) & Inspection Record No. \\
October 3,2011 & A. B. Hoffman & \\
\hline
\end{tabular}


RCL inventory

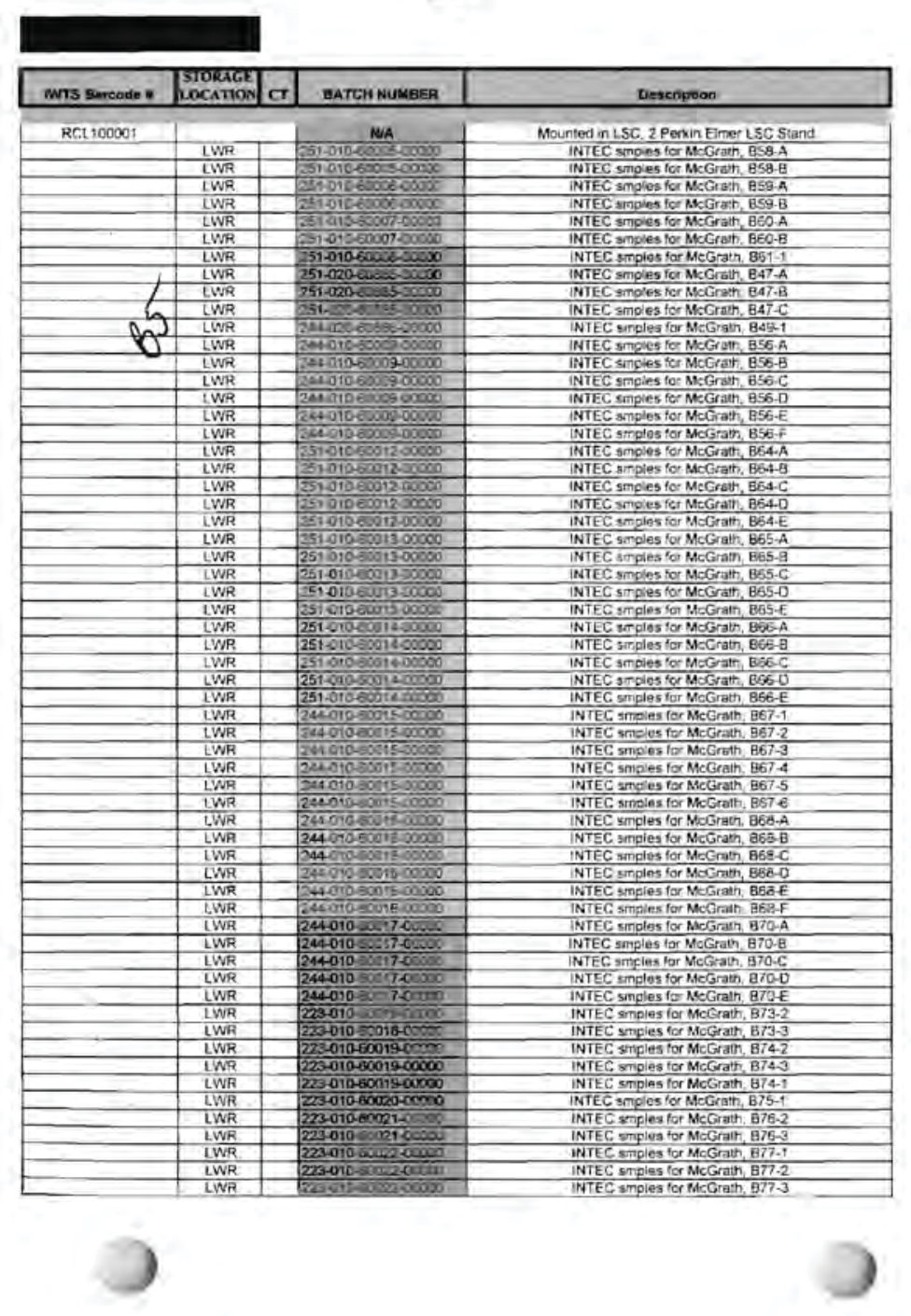




\begin{tabular}{|c|c|c|c|}
\hline & LWF & 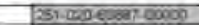 & INTEC smpins for MeGrath, GO2 \\
\hline & LWR & 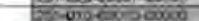 & INTEC, smples for McGrath B57-A \\
\hline & LWR & 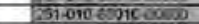 & INTEC smpies for MEGrath, B57.B \\
\hline & LWR & $751-010-5 \times 10.00000$ & INTEC sirmoles for McGrath B57-C \\
\hline & LWR & 750.000000100000 & INTEC smples for MeGrath, B63-A \\
\hline & LWR & 500000100 & INTEC smples for MECrath, 863.6 \\
\hline & LWR & 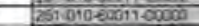 & INTEC simples for MCGrath BE3-C \\
\hline & 87 & Non Acraritions & Peter Zalupski U. 239 \\
\hline & B7 & Non Acosentasoie & Peter Zaupgki No.237 \\
\hline & 87 & Non Nasontisole & Peter Zaluoski Po-239 \\
\hline & B7 & Non Acoountoxte & Cathenne Ricosle AMA-2.4J Oxioe 3miHNO3 \\
\hline & Conter 1 & Fion Accoventes & RAD-NPELLOCO2, 74507B-370 \\
\hline & Countert & 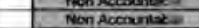 & RAD-NP-1.0002, $89565-370$ \\
\hline & Counter 1 & Hon Acrounsole & RAD-NP-10002 72131370 \\
\hline & $\frac{8}{87}$ & 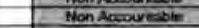 & Eu-154 Source \\
\hline & $8 \overline{7}$ & Won Masuratele & $\mathrm{Cm} .248$ seiution $25 \mathrm{~mL}(0.155 \mathrm{mz} / \mathrm{ml})$ tor Leigh Martin \\
\hline & B⿺ & 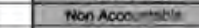 & Riddie Pu-239 Vial i, $20 \mathrm{~mL}$ (20Mq Pu+100Mg of BM HNNO3) \\
\hline & $8 \theta$ & $24+1000000$ & $N^{p}-237$ in 52 mL solution \\
\hline & $\mathrm{BB}$ & cestizonson & NP.237 for Mincher 018 \\
\hline & 87 & 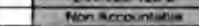 & Am-243ICPMS Lievid \\
\hline & 87 & Non Accountablo & Am-243 ICPMS Liquid CR samgie \\
\hline Of Sile Vendor & & Non Acroun atia & Specific isatopes Eu-154 \\
\hline Otl Site Vendor & & Fon ACCOUnLEbles & Specificisotopes $\mathrm{Np}-2.37$ \\
\hline Ofr Site Vendor & & Non Acrountaile & Specific isotopes Pu $_{\mathrm{u}}-239$ \\
\hline On Sile Vandor & & Non Accournabio & Speaficisotopes U-233 \\
\hline & & & \\
\hline
\end{tabular}




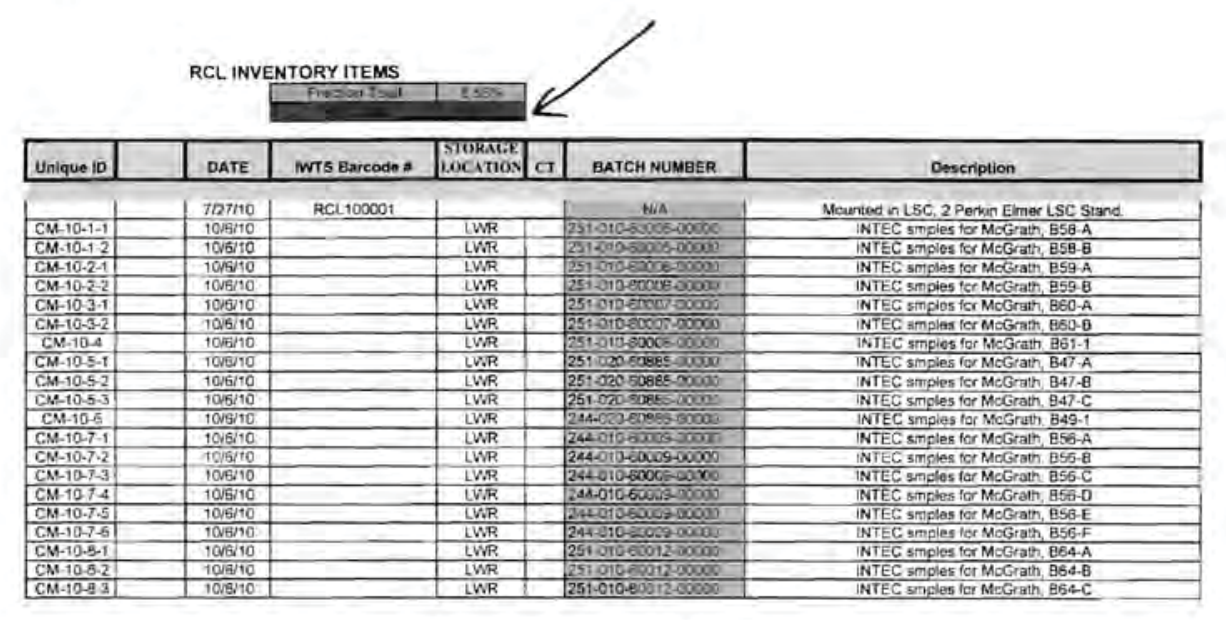

This is alec database inventory at BCL sent by J. merrill (CSO) 


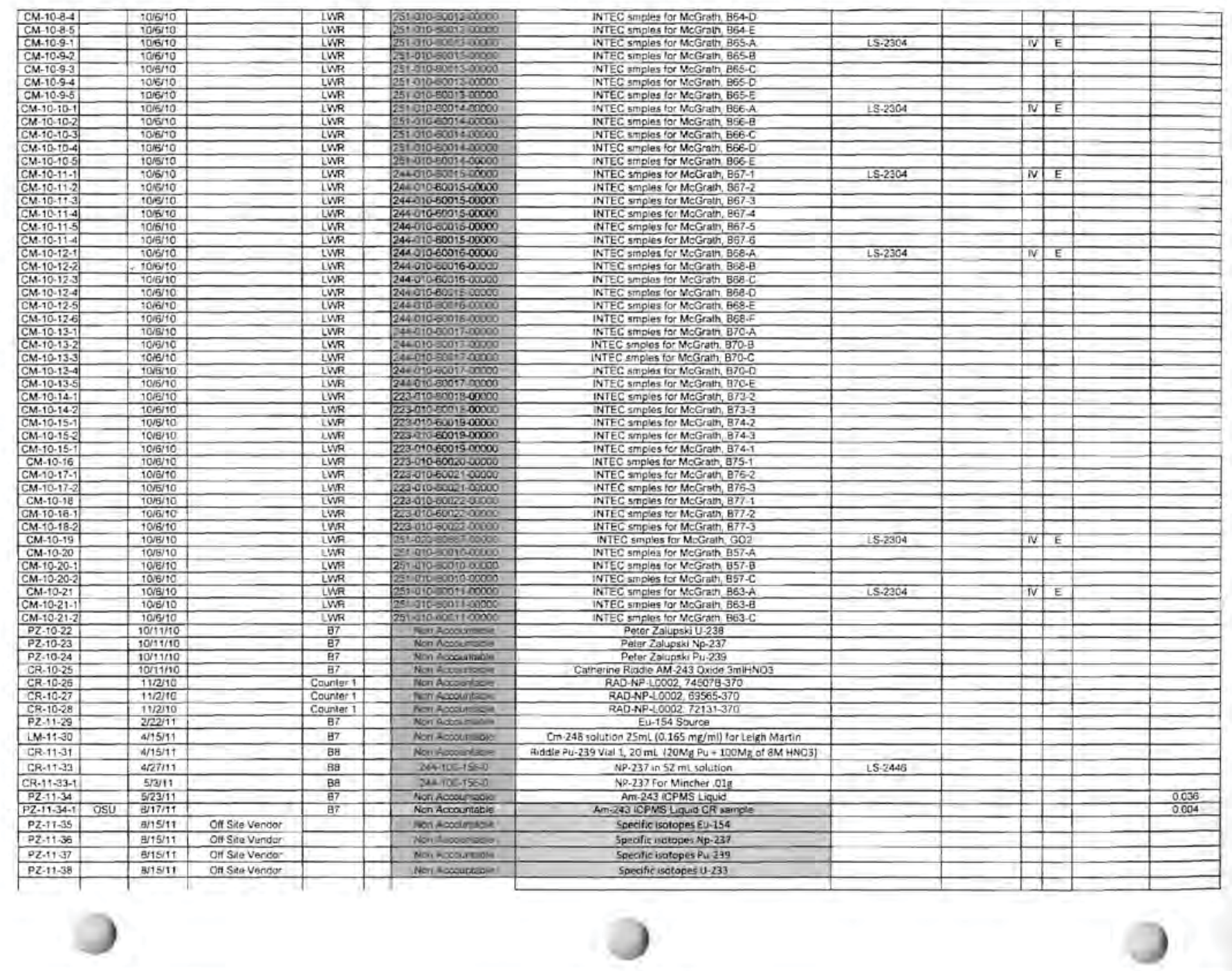



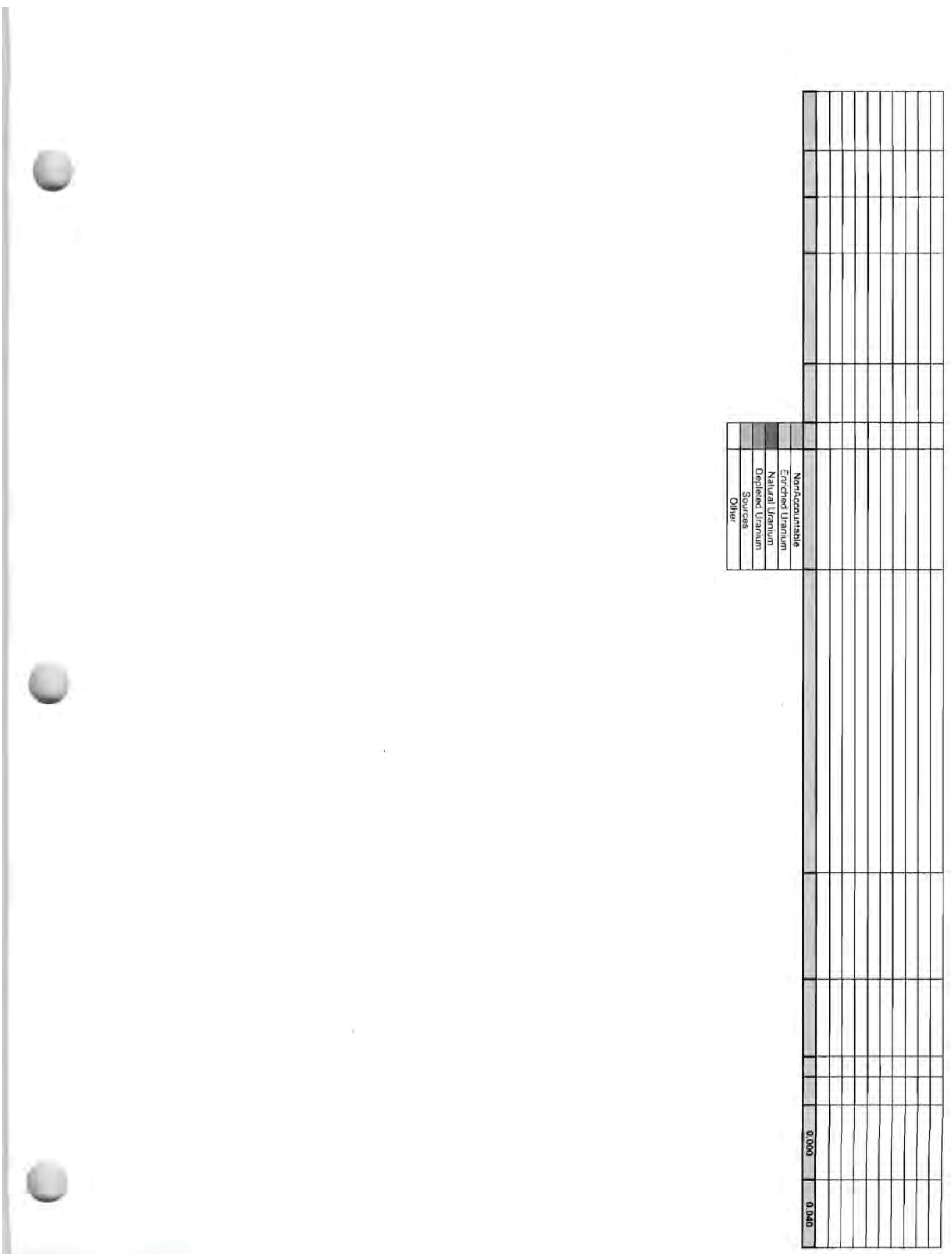


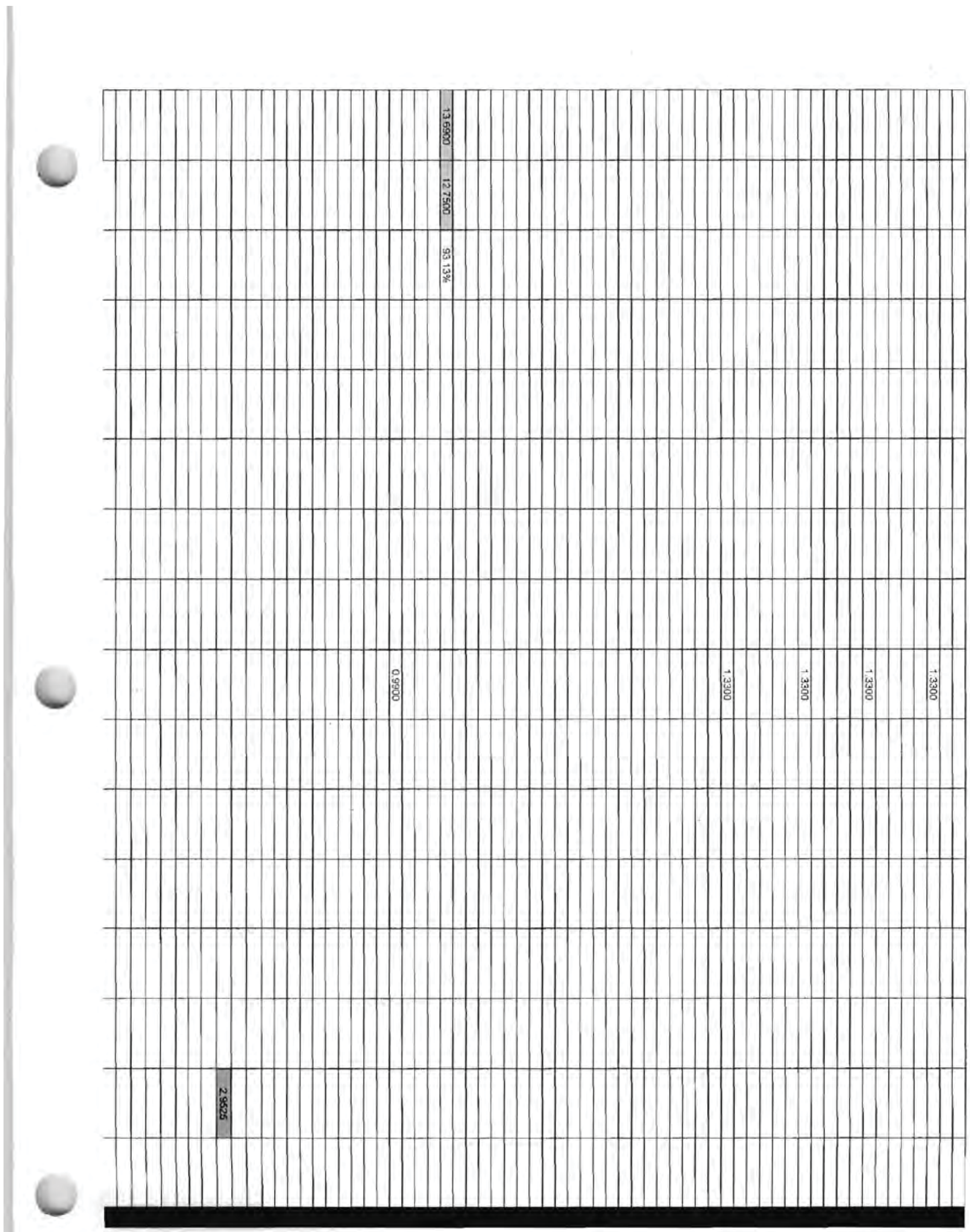




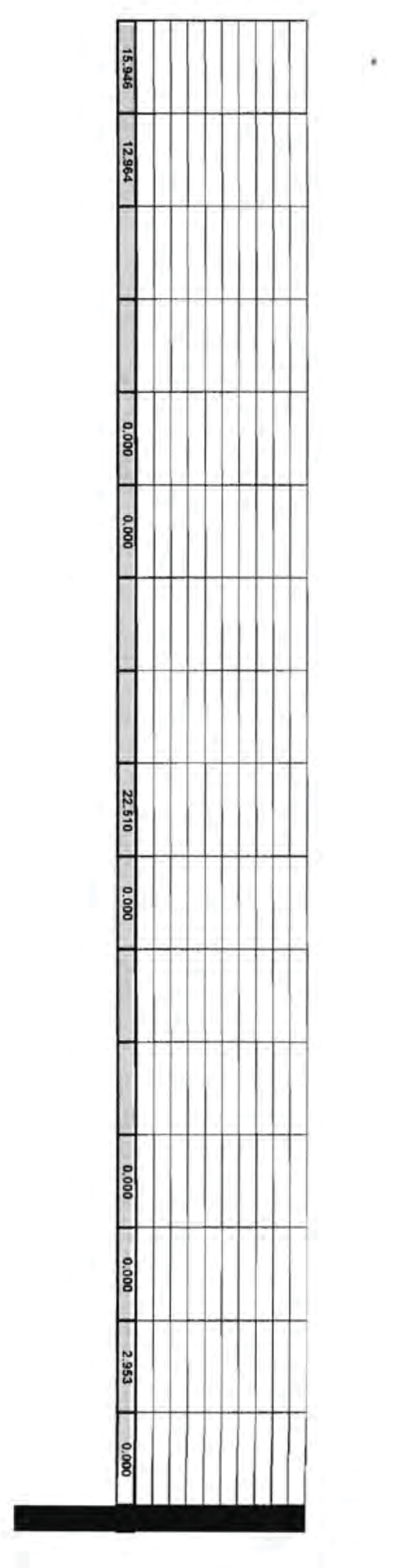




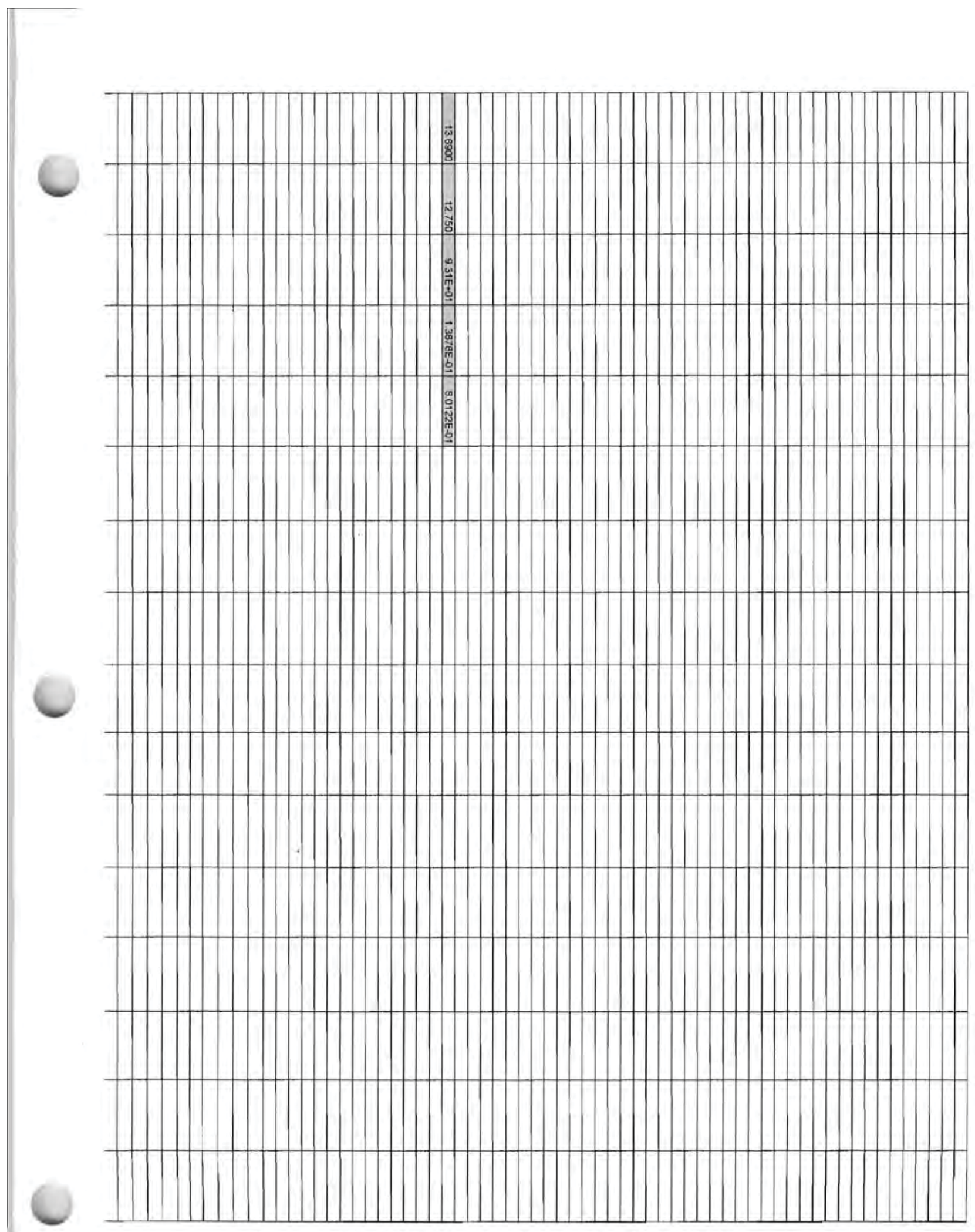




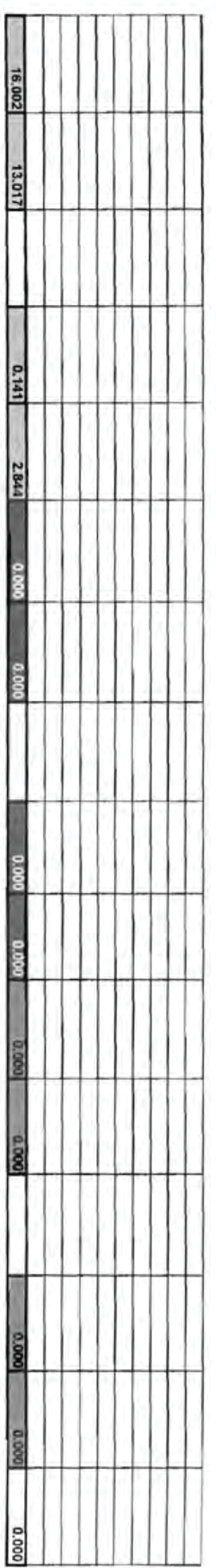


This page intentionally blank 


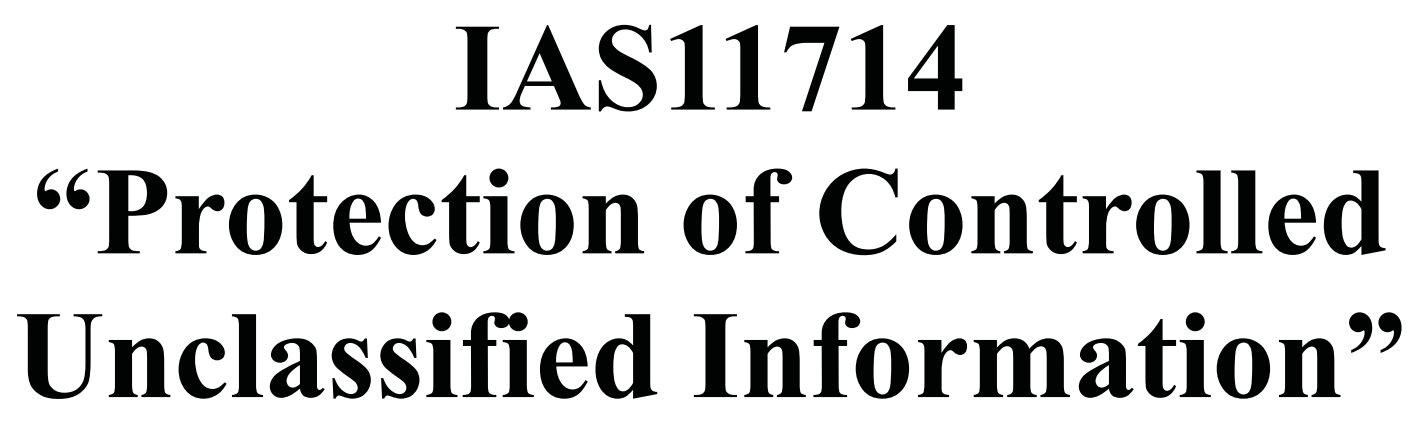




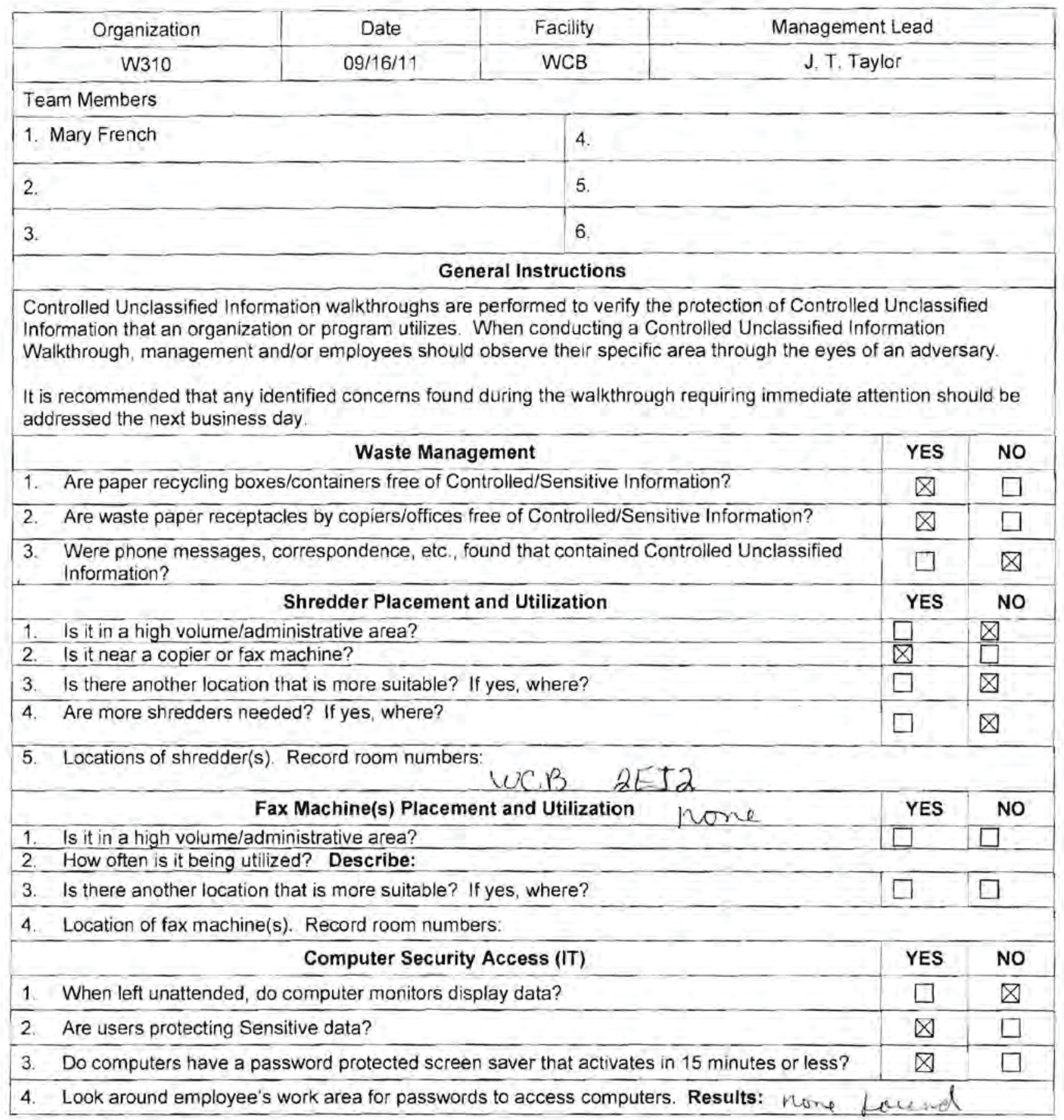




\section{IDAHO NATIONAL LABORATORY CONTROLLED UNCLASSIFIED INFORMATION (CUI) WALKTHROUGH DATA COLLECTION FORM}

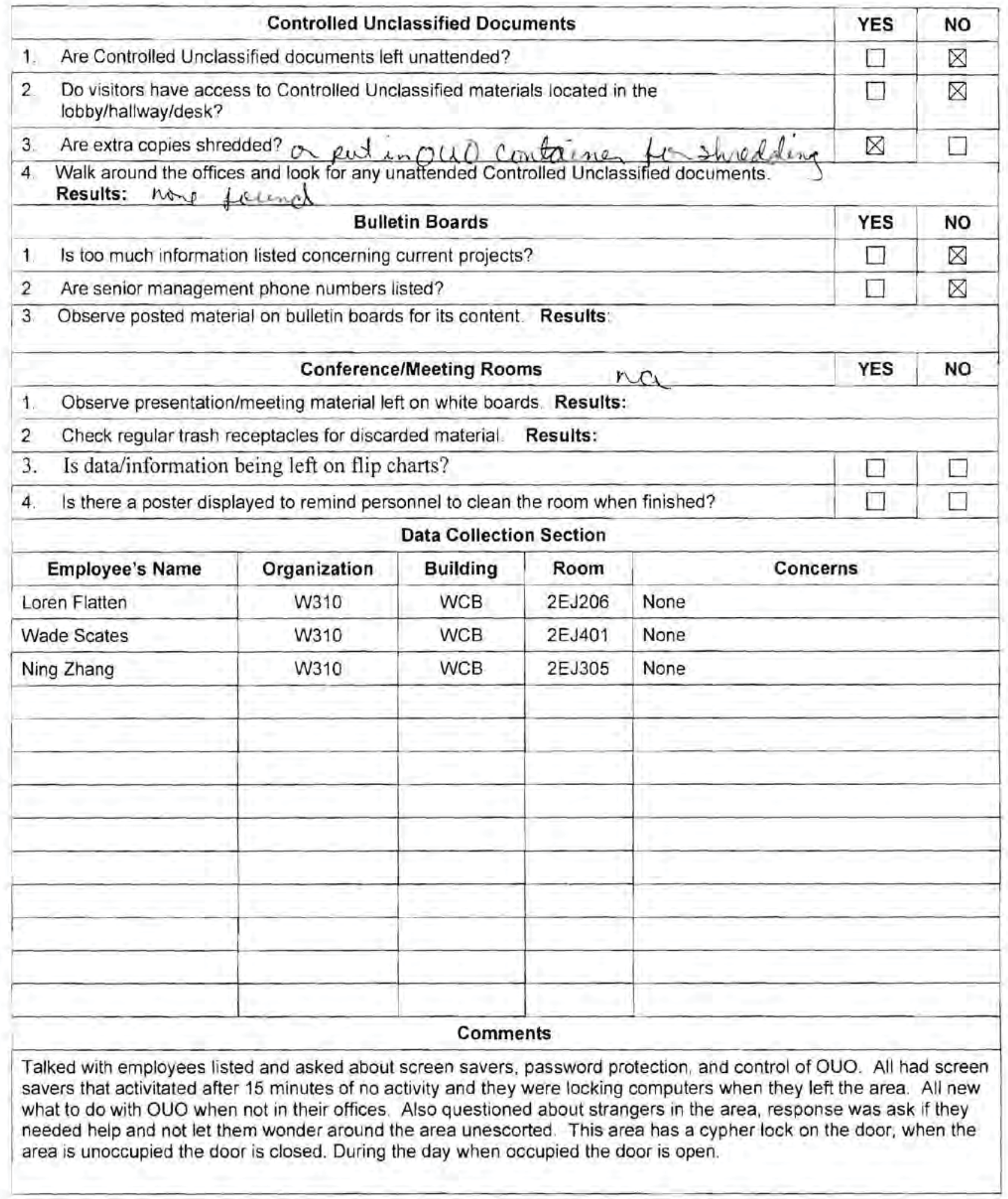




\section{IAS111705}

"Assessment of Criticality Safety

Software Quality Assurance (SQA)" 
Assessment Planning

\section{Integrated Assessment System (IAS) Number: 111705}

2. Evaluation Dates:

June 20,2011 to September 30, 2011

\section{Assessment Type:}

$\square$ Independent $\square$ Surveillance

$\square$ Management $\otimes$ Inspection

\section{Assessment Title: Assessment of Criticality Safety SQA}

5. Purpose and Scope: (facility, areas, process, activity, and/or topics to be evaluated.)

Evaluate and document the compliance of the Criticality Safety Analysis Software Application and its components with applicable Software Quality Assurance requirements identified by INL Form 562.33 Rev. 7

6. Source Requirements: DOE O 414.1C, NQA-1-2000
7. Procedures used to evaluate conditions during inspection:

LWP-13620 Rev. 11, LWP-13740 Rev. 2, NS-18211 Rev. 0, NS-18201 Rev. 4

8. Personnel performing assessment: Valerie L. Putman

9. Application(s):

Criticality Safety Analysis Software (EA ID 229244)

13. Interviewee(s)/Organization/Functional Title:

Interviewee \#1: Leland M. Montierth Printed Name

Interviewee \#2: Paul J. Sentieri Printed Name

Interviewee \#3: Ning Zhang Printed Name

Interviewee \#4: Andrea B. Hoffman Printed Name

Interviewee \#5: Charles E. Stuart Printed Name
10. Quality Level: Quality Level 2
11. Safety Classification:

Safety and Hazard Analysis and Design Software
12. Software Type: Acquired
Criticality Safety Engineering Organization

Criticality Safety Engineering Organization

Criticality Safety Engineering Organization

Criticality Safety Engineering Organization Criticality Safety Engineering Organization
Software Technical Lead (STL) Functional Title

Test Case Engineer (TCE)

Functional Title

TCE, Criticality Safety Engineer

Functional Title

Quality Level Analyst

Functional Title

Criticality Safety Engineer

Functional Title
June $20-30,2011$

Date

July 12,2011

Date

June 21.2011

Date

June 22. 2011

Date

June 22, 2011 Date

14. Management Concurrence of Assessment Plan and Checklist

J. Todd Tavlor

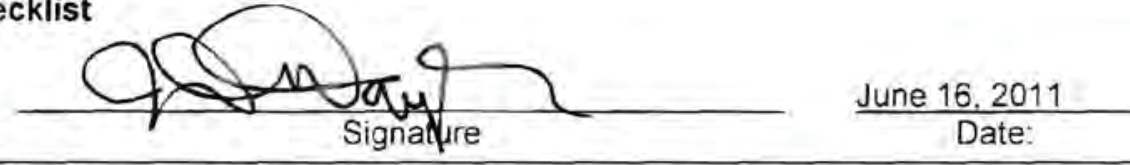




\section{Assessment Summary}

15. Summary of Potential Issues, Observations, and Noteworthy Practices:

The Criticality Safety Analysis application complies with the identified, applicable requirements. There are no potential issues or adverse observations.

This inspection identifies several suggestions for improvement of plan NS-18211. These suggestions may be evaluated during the next regularly scheduled plan review.

\section{Approval of Assessment Results:}

Assessment Team Lead:

Valerie L. Putman Printed Name

Valowiospuman

Cognizant Director / Manager:

J. Todd Tavlor

Printed Name
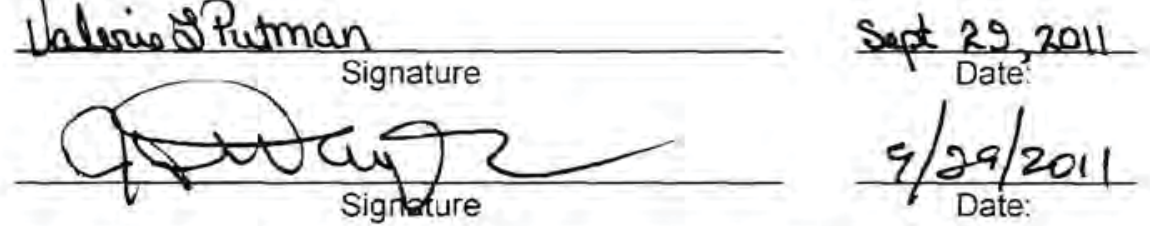


\begin{tabular}{|c|c|c|c|c|}
\hline \multicolumn{2}{|c|}{ No. Item } & Requirement & Resuits & Objective Evidence \\
\hline \multicolumn{5}{|c|}{ Planning } \\
\hline 1 & $\begin{array}{l}\text { Has the software been categorized appropriately per } \\
\text { LWP- } 13620 \text { for being non-safety or safety software? } \\
\text { [Safety software determinations (SSD) must be } \\
\text { documented and approved in the SSD database.] }\end{array}$ & $\begin{array}{l}\text { LWP-13620 Step } 4.1 .3 \\
\text { LRD-13600, Step } 3.1 .4 \\
\text { DOE O } 414.1 \text { C Att } 2 \\
\text { Section } 2 a(1), 5 \mathrm{~b} \\
\text { DOE G } 414.1-4 \text { App F } \\
\text { Section F.5.2, F.5.7 } \\
\text { NQA-1 2000 Req't } 2 \text { Para } \\
\text { 100(a), Req't } 3 \text { Para } \\
801.4\end{array}$ & $\begin{array}{l}\square \text { Acceptable } \\
\square \text { Unacceptable } \\
\square \text { Not Applicable }\end{array}$ & $\begin{array}{l}\text { SSD Number: SSD-000171, "Criticality } \\
\text { Safety Analysis Software," Rev. 0, } \\
25 \text { Jan } 2010 . \\
\text { Safety Software Category: Safety \& Hazard } \\
\text { Analysis Software \& Design Software } \\
\text { Discussion: }\end{array}$ \\
\hline 2 & $\begin{array}{l}\text { Has the Quality Level (QL) been determined per } \\
\text { LWP-13014 "Determining Quality Level Determinations" for } \\
\text { the applied use(s) that the software is being developed for? } \\
\text { [Ensure potential software risks are identified as required } \\
\text { by the grading level. } \\
\text { Ensure that the likelihood and consequences of software } \\
\text { failure are determined and documented] }\end{array}$ & $\begin{array}{l}\text { LWP-13620 Step 4.1.4 } \\
\text { LRD-13600, Step } 3.1 .4 \\
\text { DOE O 414.1C Att } 2 \\
\text { Section 2a(1), 5b } \\
\text { DOE G 414.1-4 App F } \\
\text { Section F.5.2, F.5.7 } \\
\text { NQA-1 2000 Req't 2 Para } \\
\text { 100(a), Req't 3 Para } \\
801.4\end{array}$ & $\begin{array}{l}\text { 冈 Acceptable } \\
\square \text { Unacceptable } \\
\square \text { Not Applicable }\end{array}$ & $\begin{array}{l}\text { Quality Level ID: ALL-000637, "Quality } \\
\text { Level Determination, Safety Software } \\
\text { Analysis, Criticality Safety Analysis } \\
\text { Software," Rev. 1, } 11 \text { Jan } 2010 . \\
\text { Quality Level: } 2 \\
\text { Discussion: }\end{array}$ \\
\hline 3 & $\begin{array}{l}\text { Has the software type been determined per the "INL } \\
\text { Software Type Hierarchy" for the applications being } \\
\text { reviewed or audited? }\end{array}$ & $\begin{array}{l}\text { LWP-13620 Step 4.1.13 } \\
\text { LRD-13600, Step 3.1.4 } \\
\text { DOE 0 414.1C Att } 2 \\
\text { Section 2a(1), 5b } \\
\text { DOE G 414.1-4 App F } \\
\text { Section F 5.2, F } 5.7 \\
\text { NQA-1 2000 Req't 2 Para } \\
\text { 100(a), Req't 3 Para } \\
801.4\end{array}$ & $\begin{array}{l}\square \text { Acceptable } \\
\square \text { Unacceptable } \\
\square \text { Not Applicable }\end{array}$ & $\begin{array}{l}\text { Software Type: Each software package is } \\
\text { acquired, analysis software. Each } \\
\text { operating system is acquired, support } \\
\text { system software. } \\
\text { Discussion: NS-18211, "Criticality Safety } \\
\text { Analysis Software," } \$ 4.2 \text { identifies each } \\
\text { type. The identification could be improved if } \\
\text { if appeared in } \$ 4.1 \text {, rather than } \$ 4.2 \text {, of } \\
\text { NS-18211 and if the text included the } \\
\text { phrase, "Software Type Hierarchy." } \\
\text { Criticality Safety Engineering should also } \\
\text { consider incorporating, during the next } \\
\text { revision of NS-18211, the phrase, } \\
\text { "commercial off-the-shelf software, "to } \\
\text { further clarify reasons NS-18211 does not } \\
\text { include some SQA activities. }\end{array}$ \\
\hline 4 & $\begin{array}{l}\text { Has the required training been completed for safety and/or } \\
\text { non-safety software? } \\
\text { [Ensure a training or indoctrination program exists for }\end{array}$ & $\begin{array}{l}\text { LWP-13620 Step } 4.1 .7 \\
\text { Table } 2 \\
\text { LRD-13600 Step } 3.1 .4 \\
\text { DOE } 0414.1 \text { C Att } 2\end{array}$ & $\begin{array}{l}\square \text { Acceptable } \\
\square \text { Unacceptable } \\
\square \text { Not Applicable }\end{array}$ & $\begin{array}{l}\text { EA Number: } 229244 \\
\text { Training Plan: NS-18211 §3 }\end{array}$ \\
\hline
\end{tabular}




\begin{tabular}{|c|c|c|c|c|}
\hline No. & Item & Requirement & Results & Objective Evidence \\
\hline & $\begin{array}{l}\text { safety software analysis, development, operations and use, } \\
\text { and assessmentlevaluation. } \\
\text { Ensure the training program provides for continuing } \\
\text { education and is adequate for the scope, complexity, and } \\
\text { importance of the tasks being performed. } \\
\text { Ensure training is commensurate with the education. } \\
\text { experience, and proficiency of the person.] }\end{array}$ & $\begin{array}{l}\text { Section } 3 b, 5 d(10) \\
\text { DOE G 414.1-4 App F } \\
\text { Section F.5.10 } \\
\text { NQA-1 } 2000 \text { Req't } 2 \text { Para } \\
200\end{array}$ & & 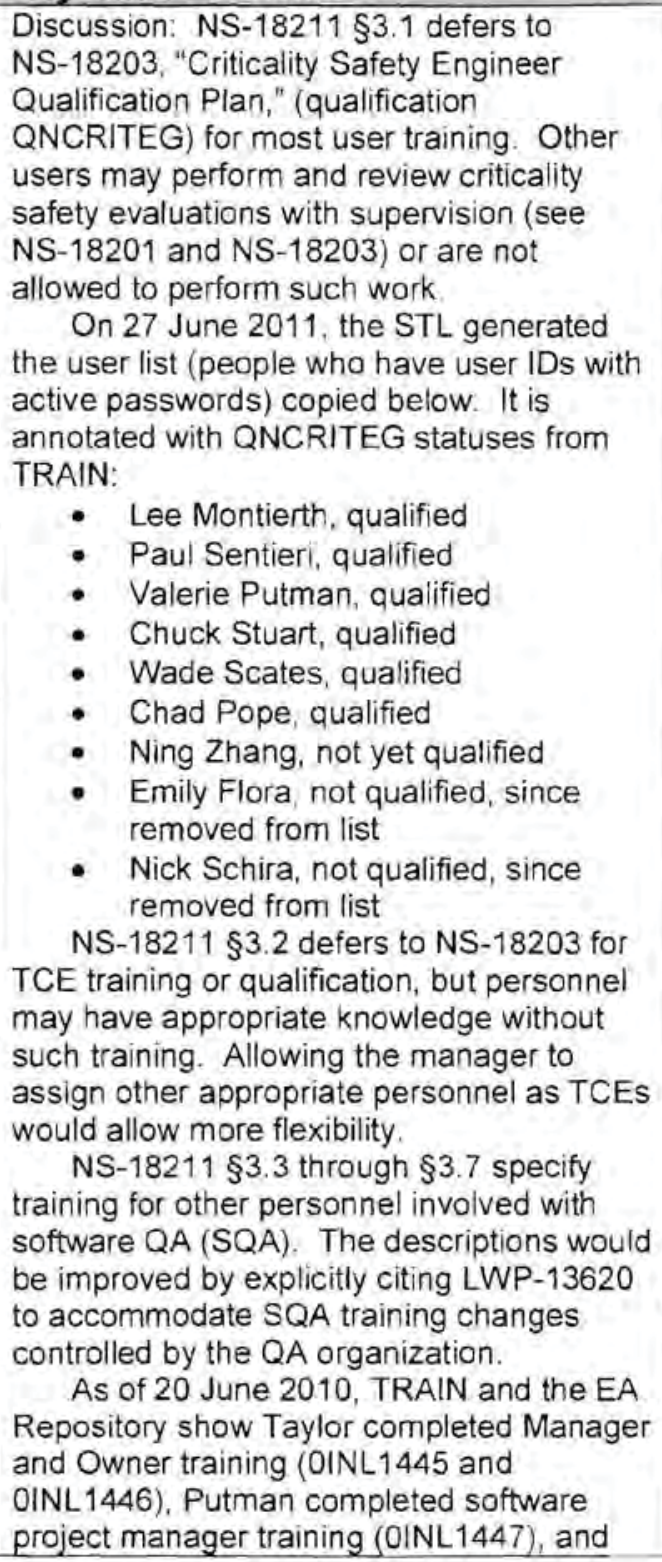 \\
\hline
\end{tabular}




\begin{tabular}{|c|c|c|c|c|}
\hline No. & Item & Requirement & Results & Objective Evidence \\
\hline & & & & $\begin{array}{l}\text { Montierth completed STL training } \\
\text { (OINL1448) The criticality safety analysis } \\
\text { application does not require a content } \\
\text { manager or software developers. } \\
\text { As of } 28 \text { September } 2011 \text {, all } \\
\text { application users and personnel involved } \\
\text { with the application's SQA have } \\
\text { qualification QNSQASSQ. }\end{array}$ \\
\hline 5 & $\begin{array}{l}\text { Has the appropriate software application information been } \\
\text { entered into the Enterprise Architecture (EA) Repository } \\
\text { and is it complete, up-to-date, and verified? } \\
\text { [The EA record must be verified to ensure completeness. } \\
\text { For safety software, ensure the application software is } \\
\text { included on the safety software list]. }\end{array}$ & $\begin{array}{l}\text { LWP-13620 Step } 4.1 .14 \\
\text { LWP-1313 } \\
\text { LRD-13600 Step } 3.1 .4 \\
\text { DOE O } 414.1 \text { C Att } 2 \\
\text { Section } 5 \text { b } \\
\text { DOE G } 414.1-4 \text { App F } \\
\text { Section F.5.1 } \\
\text { NQA-1-2000 Subpart } 2.7 \\
\text { Para } 400\end{array}$ & $\begin{array}{l}\square \text { Acceptable } \\
\square \text { Unacceptable } \\
\square \text { Not Applicable }\end{array}$ & $\begin{array}{l}\text { EA Number: } 229244 \\
\text { Discussion: The SPM last verified baseline } \\
\text { data, as listed in the EA Repository, on } \\
26 \text { April } 2011 \text {. She incorporated the } \\
\text { following updates since then: } \\
\text { 15 June 2011: linked the SCALE } 6.0 \\
\text { software package to the application. } \\
\text { 20 June 2011: submitted a records } \\
\text { analysis, which is now approved. } \\
\text { - } 7 \text { June 2011: retired the SCALE } 5.1 \\
\text { (EA ID 202165) and PARTISN } 4.0 \\
\text { (EA ID 202166). }\end{array}$ \\
\hline 6 & $\begin{array}{l}\text { Are management plans (i.e, software management plans, } \\
\text { software quality assurance plans, software configuration } \\
\text { management plans, software test plans) or equivalent } \\
\text { implemented and controlled for managing the software } \\
\text { application lifecycle and approved by management? } \\
\text { [Ensure software project management and quality planning } \\
\text { has been implemented depicting organization structure, } \\
\text { responsibilities, and authorities for those managing. } \\
\text { performing and assessing the software projects.] }\end{array}$ & $\begin{array}{l}\text { LWP-13620 Step 4.5.1.4 } \\
\text { EXH-13620-1, } \\
\text { EXH-13620-2, } \\
\text { EXH-13620-3 } \\
\text { LRD-13600, Steps 3.1.1, } \\
3.1 .2 \\
\text { DOE O 414.1C Att } 2 \\
\text { Section 3d, 5d(1) } \\
\text { DOE G 414.1-4 App F } \\
\text { Section F.5.1 } \\
\text { NQA-1-2000 Subpart } 2.7 \\
\text { Para } 400\end{array}$ & $\begin{array}{l}\text { 冈 Acceptable } \\
\square \text { Unacceptable } \\
\square \text { Not Applicable }\end{array}$ & $\begin{array}{l}\text { Software Management Plan; NS-18211, } \\
\text { especially } \$ 1, \S 4 \text { and Attachment C. } \\
\text { Software Configuration Management Plan: } \\
\text { NS-18211, especially } \$ 7, \S 8, \S 9, \text { and } \\
\text { Attachment C. } \\
\text { Software Quality Assurance Plan: } \\
\text { NS-18211, especially } \$ 5,6, \S 6, \S 9, \S 10, \\
\text { Attachment A, and Attachment D } \\
\text { Software Test Plan: NS-18211 } \S 5 \text { and } \\
\text { Attachment E } \\
\text { Discussion: }\end{array}$ \\
\hline 7 & $\begin{array}{l}\text { Are records (e.g., management plans, configuration item } \\
\text { lists, approved user lists) being maintained according to the } \\
\text { organization, program, or project records management } \\
\text { plan? }\end{array}$ & $\begin{array}{l}\text { LWP-13620 Step 4.5.1.6 } \\
\text { LWP-1202 } \\
\text { LRD-1201 } \\
\text { DOE O } 414 \text {-1C Att } 2 \\
\quad \text { Section 3d, } 5 d(1)\end{array}$ & $\begin{array}{l}\text { Acceptable } \\
\square \text { Unacceptable } \\
\square \text { Not Applicable }\end{array}$ & $\begin{array}{l}\text { Records Coordinator: Mary E. French } \\
\text { Records Management Plan: NS-18305. } \\
\text { NS-18211 Attachment B provides } \\
\text { supplemental information/instructions. }\end{array}$ \\
\hline
\end{tabular}




\begin{tabular}{|c|c|c|c|c|}
\hline No. & Ifem & Requirement & Results & Objective Evidence \\
\hline & & $\begin{array}{l}\text { DOE G 414.1-4 App F } \\
\text { Section F.5.1 } \\
\text { NQA-1-2000 Req' } 6,17\end{array}$ & & 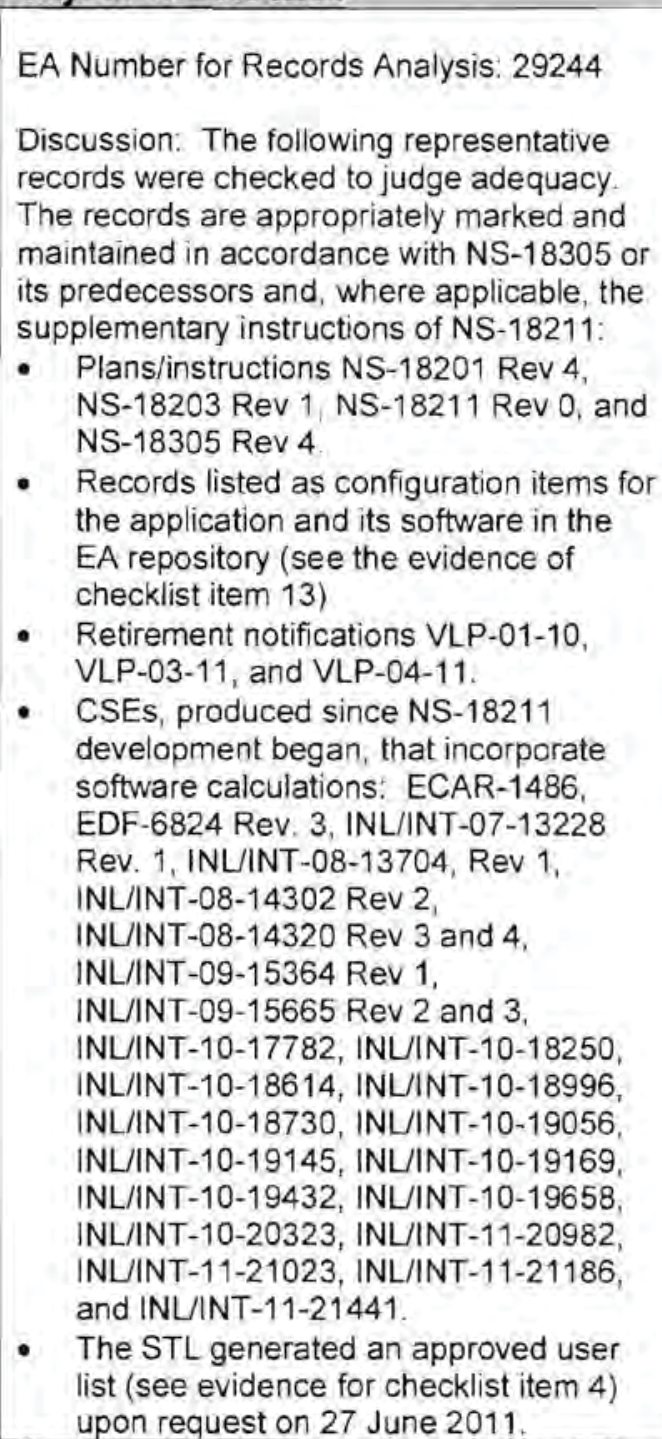 \\
\hline 8 & $\begin{array}{l}\text { Are requirements including access control being } \\
\text { adequately captured, documented, approved by the } \\
\text { Software Owner, and managed based on the quality level }\end{array}$ & $\begin{array}{l}\text { LWP-13620 Step } 4.5 .2 .1 \\
\text { EXH-13620-1, } \\
\text { EXH-13620-2, }\end{array}$ & $\begin{array}{l}\bigotimes \text { Acceptable } \\
\square \text { Unacceptable } \\
\square \text { Not Applicable }\end{array}$ & $\begin{array}{l}\text { Document Identifier: NS-18211 } \$ 4.3, \S 8.4 \text {, } \\
\text { and Attachments A and D. }\end{array}$ \\
\hline
\end{tabular}




\begin{tabular}{|c|c|c|c|}
\hline No. & Item & Requirement & Results \\
\hline & $\begin{array}{l}\text { and software type (e.g., is the requirements baseline up-to- } \\
\text { date)? } \\
\text { [Ensure software functions, requirements, and their bases } \\
\text { are defined, documented and managed throughout the } \\
\text { software life-cycle. Changes to requirements must be } \\
\text { reflected in all documentation. For safety software, } \\
\text { software requirements must be consistent with system } \\
\text { safety basis.] }\end{array}$ & $\begin{array}{l}\text { EXH-13620-3 } \\
\text { LRD-13600, Step 3.3.2 } \\
\text { DOE 0 414.1C Att } 2 \\
\text { Section 3d, 5d(5) } \\
\text { DOE G 414.1-4 App F } \\
\text { Section F.5.5 } \\
\text { NQA-1-2000 Req't 3 Para } \\
\text { 801.1, Subpart 2.7 } \\
\text { Para 401 } \\
\text { NQA-1-2000 Subpart } 2.7 \\
\text { Para 405 }\end{array}$ & \\
\hline 9 & $\begin{array}{l}\text { Has the system design been adequately captured and } \\
\text { documented based on the quality level and software type? } \\
\text { [Ensure the design is described in a manner suitable for } \\
\text { translating into computer codes. The design, including } \\
\text { interfaces and data structures, must be correct, consistent, } \\
\text { clearly presented, and feasible. } \\
\text { Design should include a description of major safety } \\
\text { components; a technical description of the software with } \\
\text { respect to control flow, logic, mathematical model, data } \\
\text { structure and integrity, and interface; a description of inputs } \\
\text { and outputs including allowable or prescribed ranges for } \\
\text { inputs and outputs; a description of error handling } \\
\text { strategies and the use of the interrupt protocols.] }\end{array}$ & $\begin{array}{l}\text { LWP-13620 Step 4.5.3.1, } \\
\text { EXH-13620-1, } \\
\text { EXH-13620-2, } \\
\text { EXH-13620-3 } \\
\text { LRD-13600, Step 3.3.3 } \\
\text { DOE 0 414.1C Att 2 } \\
\text { Section 3d, 3f, 5d(6) } \\
\text { DOE G 414.1-4 App F } \\
\text { Section F.5.6 } \\
\text { NQA-1-2000 Req't 3 Para } \\
\text { 801.2, Subpart 2.7 } \\
\text { Para 402 }\end{array}$ & $\begin{array}{l}\square \text { Acceptable } \\
\square \text { Unacceptable } \\
\square \text { Not Applicable }\end{array}$ \\
\hline 10 & $\begin{array}{l}\text { Have design, programming, and database standards been } \\
\text { followed? } \\
\text { [Ensure the design has been translated into computer } \\
\text { program(s) using the organizations program standards and } \\
\text { conventions?] }\end{array}$ & $\begin{array}{l}\text { LWP-13620 Step 4.5.4.3 } \\
\text { LRD-13600. Step 3.5.1 } \\
\text { DOE 0 414.1C Att } 2 \\
\text { Section } 3 f, 5 d(6) \\
\text { DOE G } 414.1-4 \text { App F } \\
\text { Section F.5.6 } \\
\text { NQA-1-2000 Req't } 3 \text { Para } \\
\text { 801.3, Subpart } 2.7403\end{array}$ & $\begin{array}{l}\square \text { Acceptable } \\
\square \text { Unacceptable } \\
\square \text { Not Applicable }\end{array}$ \\
\hline
\end{tabular}

\section{Objective Evidence}

Discussion:

Document Identifier:

Discussion: Item 9 is N/A because the application uses only acquired, commercial off-the-shelf software. Code developers and/or distributors must provide the technical description. NS-18211 requires that acquired codes be well-characterized which necessarily requires such technical descriptions.

\section{Document/Standard Identifier:}

Discussion: Item 10 is N/A because the application uses only acquired, commercial off-the-shelf software. Code developers must identify and apply appropriate standards, documenting such activities The application currently includes SCALE 6.0, MCNP5 1.40, and MCNP5 1.51, developed by DOE contractors subject to DOE orders and guides as specified in their contracts

- SCALE developers comply with plan SCALE-QAP-005 Rev. 3 (http://www ornl.gov/sci/scale/pubs/ 


\begin{tabular}{|c|c|c|c|c|}
\hline No. & Item & Requirement & Results & Objective Evidence \\
\hline & & & & $\begin{array}{l}\text { Scale-qap-005r3.pdf), which invokes } \\
\text { 10 CFR 830 Subpart A and } \\
\text { ASME NQA-1-1994 part } 1 \text { and } \\
\text { subpart 2.7. } \\
\text { MCNP developers comply with } \\
\text { LANL procedure P1040 Rev. 1, } \\
\text { "Software Quality Management", } \\
\text { which invokes } 10 \text { CFR } 830 \\
\text { Subpart A and DOE Order } 414.1 \text {. } \\
\text { Rev. 2, which invokes NQA-1 (no } \\
\text { date) and DOE G 414.1-4, will be } \\
\text { effective in September 2011. } \\
\text { NS-18211 Attachment D requires each } \\
\text { software package be well characterized, } \\
\text { which necessarily requires the availability of } \\
\text { this documentation. (See the suggested } \\
\text { improvement for checklist item } 9 \text { ). }\end{array}$ \\
\hline 11 & $\begin{array}{l}\text { Is a user manual, on-line help, desktop procedures, or a } \\
\text { training guide available? } \\
\text { [Ensure instructions for use of the software, within the limits } \\
\text { of the system's capabilities, are available.] }\end{array}$ & $\begin{array}{l}\text { LWP-13620 Step 4.5.4.1, } \\
\text { EXH-13620-1, } \\
\text { EXH-13620-2, } \\
\text { Step 4.2.3.1 B, 4.3.1 B } \\
\text { LRD-13600, Step 3.2.2.4, } \\
3.5 .2 \\
\text { DOE O 414.1C Att } 2 \\
\text { Section 3d, 3f, 5d(6) } \\
\text { DOE G 414.1-4 App F } \\
\text { Section F.5.6 } \\
\text { NQA-1-2000 Subpart } 2.7 \\
\text { Para } 302,403\end{array}$ & $\begin{array}{l}\square \text { Acceptable } \\
\square \text { Unacceptable } \\
\square \text { Not Applicable }\end{array}$ & $\begin{array}{l}\text { Document Identifier: As identified in the } \\
\text { V\&V report and acceptance notification of } \\
\text { each software package. } \\
\text { Discussion: Plan NS-18211 Attachment D } \\
\text { requires each software package have } \\
\text { documentation to assist users. Item } 6.6 \text { of } \\
\text { Table A1 in the plan requires acceptance } \\
\text { notices identify such user aids. }\end{array}$ \\
\hline 12 & $\begin{array}{l}\text { Have verification (e.g., desktop reviews, inspections, unit } \\
\text { tests, alternate calculations) activities been completed by } \\
\text { personnel not involved with development of the work } \\
\text { product and documented? NOTE: QL-1 V\&V activities } \\
\text { require an INL qualified Quality Engineer } \\
\text { [Ensure V\&V activities are performed by competent staff } \\
\text { other than those who developed the item being verified or } \\
\text { validated] }\end{array}$ & $\begin{array}{l}\text { LWP-13620 Step 4.5.4.3 } \\
\text { LRD-13600. Step 3.5.1 } \\
\text { DOE O 414.1C Att } 2 \\
\text { Section 3f, 5d(6) } \\
\text { DOE G 414.1-4 App F } \\
\text { Section F.5.6 } \\
\text { NQA-1-2000 Req't 3 Para } \\
801.3 \text {, Subpart 2.7 } 403\end{array}$ & $\begin{array}{l}\triangle \text { Acceptable } \\
\square \text { Unacceptable } \\
\square \text { Not Applicable }\end{array}$ & $\begin{array}{l}\text { Document Identifier: Representative } \\
\text { documents: } \\
\text { - Package-specific V\&V reports for } \\
\text { installation acceptance (see evidence } \\
\text { for checklist item 13) } \\
\text { - } \$ 4 \text { of each CSE for evaluation-specific } \\
\text { calculation validation (see evidence for } \\
\text { checklist item 7). } \\
\text { Discussion: Criticality Safety Engineering } \\
\text { personnel, who perform acceptance tests, } \\
\text { are independent of personnel who develop }\end{array}$ \\
\hline
\end{tabular}




\begin{tabular}{|c|c|c|c|c|}
\hline \multicolumn{2}{|c|}{ No. Item } & Requirement & Results & Objective Evidence \\
\hline & & & & $\begin{array}{l}\text { the acquired codes, } \\
\quad \text { NS- } 18201 \text { specifies the independence } \\
\text { needed for checking software calculations } \\
\text { used in CSEs. Criticality Safety } \\
\text { Engineering reviewed NS- } 18201 \text { to } \\
\text { determine if revision is needed to implement } \\
\text { a proposed new instruction LWP-10106, } \\
\text { "Checking and Verification," for verification } \\
\text { of calculation results. } \\
\text { V\&V reports, NS-18211 and NS-18201 } \\
\text { do not require a Quality Engineer review } \\
\text { because the application and CSEs are QL-2 } \\
\text { as determined with ALL-000637 and } \\
\text { ALL-00507. }\end{array}$ \\
\hline 13 & $\begin{array}{l}\text { Was the software baseline established and placed under } \\
\text { configuration management prior to acceptance testing? } \\
\text { [Ensure software configuration items properly identified, } \\
\text { baselined, and controlled prior to acceptance testing and } \\
\text { release]. }\end{array}$ & $\begin{array}{l}\text { LWP-13620 Step } 4.5 .5 .4 \\
\text { LRD-13600 Step } 3.7 .4 \\
\text { DOE 0 414.1C Att } 2 \\
\text { Section 3e, 5d(3) } \\
\text { DOE G 414.1-4 App F } \\
\text { Section F.5.3 } \\
\text { NQA-1-2000, Req't 6, } \\
\text { Subpart 2.7 Para } 404\end{array}$ & $\begin{array}{l}\otimes \text { Acceptable } \\
\square \text { Unacceptable } \\
\square \text { Not Applicable }\end{array}$ & $\begin{array}{l}\text { Configuration Item List (ie, document } \\
\text { identifier, location): As identified in the EA } \\
\text { Repository for the application. The reader } \\
\text { must also follow the links to each software } \\
\text { package to identify package-specific items. } \\
\text { Discussion: As of } 26 \text { July } 2011 \text {; the } \\
\text { Repository provides the following } \\
\text { configuration item lists: } \\
\text { - Entire application EA ID 229244; plan } \\
\text { NS-18211; user information } \\
\text { INLINT-06-01380, "Criticality Dose } \\
\text { Calculation Methodology;" quality level } \\
\text { determination ALL-000637; safety } \\
\text { software determination number } \\
\text { SSD-000171; server [NAS] tut; and } \\
\text { software packages MCNP5 version } \\
1.40, \text { MCNP5 version 1.51, and SCALE } \\
\text { version 6.0 } \\
\text { Software package MCNP5 1.40, } \\
\text { EA ID } 200510 \text { : servers aten, bacchus, } \\
\text { beavis, buthead, dr-evil, dr-kim, dr-no, } \\
\text { dr-ruth, frylock, itza, ra, the-dude, and } \\
\text { tut; V\&V report INL/INT-10-19660; } \\
\text { acceptance notice VLP-02-10; and the } \\
\text { product review of EDMS record } \\
3298188 \text {. }\end{array}$ \\
\hline
\end{tabular}




\begin{tabular}{|c|c|c|c|c|}
\hline No. & Item & Requirement & Results & Objective Evidence \\
\hline & & & & $\begin{array}{l}\text { - Software package MCNP5 } 1.51 \text {, } \\
\text { EA ID } 232456 \text { : servers aten, bacchus, } \\
\text { beavis, buthead, dr-evil, dr-kim, dr-no, } \\
\text { dr-ruth, frylock, itza, ra, the-dude, and } \\
\text { tut; V\&V report INL/INT-10-19661; V\&V } \\
\text { supporting documentation EDMS record } \\
3294808 \text {, acceptance notice } \\
\text { VLP-02-10; and the product review of } \\
\text { EDMS record } 3298189 \text {. } \\
\text { Software package SCALE version } 6.0 \text {, } \\
\text { EA ID } 237870 \text { : servers aten, bacchus, } \\
\text { beavis, buthead, dr-evil, dr-kim, dr-no, } \\
\text { dr-ruth, frylock, itza, ra, the-dude, and } \\
\text { tut; V\&V report INL/INT-11-22236; and } \\
\text { acceptance notice VLP-02-11, } \\
\text { Appendix B of each V\&V report also lists a } \\
\text { package-specific configuration item list } \\
\text { applicable at the time of the V\&V. }\end{array}$ \\
\hline 14 & $\begin{array}{l}\text { Has the appropriate acceptance test documentation been } \\
\text { developed and executed by the customer based on the } \\
\text { quality level and software type and are the test cases } \\
\text { traceable to the requirements? } \\
\text { [Ensure documentation includes test plans, test cases } \\
\text { including test data and expected results. Results } \\
\text { documentation must demonstrate successful completion of } \\
\text { all test cases or the resolution of unsuccessful test cases.] } \\
\text { [Ensure design requirements are traceable throughout the } \\
\text { lifecycle and that all requirements were validated.] } \\
\text { [Ensure V\&V activities are performed by competent staff } \\
\text { other than those who developed the item being verified or } \\
\text { validated.] } \\
\text { [Ensure software configuration items properly identified, } \\
\text { baselined, and controlled prior to acceptance testing and } \\
\text { release]. }\end{array}$ & $\begin{array}{l}\text { LWP-13620 Step 4.5.5.1, } \\
\text { EXH-13620-1, } \\
\text { EXH-13620-2, } \\
\text { EXH-13620-3 } \\
\text { LRD-13600, Step } 3.7 .7 \\
\text { DOE O 414.1C Alt } 2 \\
\text { Section 3h, 5d(8) } \\
\text { DOE G 414.1-4 App F } \\
\text { Section F.5.8 } \\
\text { NQA-1-2000 Req't } 11 \\
\text { Para 400/500, Subpart } \\
\text { 2.7 Para 404 }\end{array}$ & $\begin{array}{l}\text { \Acceptable } \\
\square \text { Unacceptable } \\
\square \text { Not Applicable }\end{array}$ & $\begin{array}{l}\text { Document Identifier: } \\
\text { - NS-18211 Altachment E for the } \\
\text { acceptance testing plan of application } \\
\text { items. } \\
\text { - Software-package-specific V\&V reports } \\
\text { (see the evidence of checklist item 13) } \\
\text { NS-18201 \$4.2.8 for CSE-specific } \\
\text { calculations } \\
\text { - } \$ 4 \text { of each CSE (see the evidence of } \\
\text { checklist item 7). } \\
\text { Discussion: }\end{array}$ \\
\hline 15 & $\begin{array}{l}\text { Have problem reporting and corrective action methods } \\
\text { been documented and implemented? }\end{array}$ & $\begin{array}{l}\text { LWP-13620 Step 4.56.1, } \\
\text { EXH-13620-1, } \\
\text { EXH-13620-2, }\end{array}$ & $\begin{array}{l}\square \text { Acceptable } \\
\square \text { Unacceptable } \\
\square \text { Not Applicable }\end{array}$ & $\begin{array}{l}\text { Document Identifier: NS-18211 \$5.6 } \\
\text { Discussion: Duplicate EDMS Records }\end{array}$ \\
\hline
\end{tabular}




\begin{tabular}{|c|c|c|c|c|}
\hline No. & Item & Requirement & Resulfs & Objective Evidence \\
\hline & $\begin{array}{l}\text { [Ensure documented practices and procedures for } \\
\text { reporting, tracking, and resolving problems or issues are } \\
\text { defined and implemented. The documented procedures } \\
\text { should address methods of promptly reporting to affected } \\
\text { organizations. } \\
\text { Ensure organization responsibilities for reporting issues, } \\
\text { approving changes, and implementing corrective actions } \\
\text { are identified and found to be effective. } \\
\text { For safety software, ensure errors are correlated with the } \\
\text { proper software engineering element, identified for potential } \\
\text { impact, and all users notified] }\end{array}$ & $\begin{array}{l}\text { EXH-13620-3 } \\
\text { LRD-13600 Step } 3.8 \mathrm{C} \\
3.14 \\
\text { DOE O } 414.1 \mathrm{C} \text { Att } 2 \\
\text { Section } 3 \mathrm{C}, 5 \mathrm{~d}(9) \\
\text { DOE G } 414.1-4 \text { App F } \\
\text { Section F. } 5.9 \\
\text { NQA-1-2000 Req't } 16 \\
\text { Subpart } 2.7 \text { Para } 204 \\
405\end{array}$ & & $\begin{array}{l}329188 \text { (for MCNP5 1.40) and } 3298189 \text { (for } \\
\text { MCNP5 1.51), are examples of effective } \\
\text { implementation. }\end{array}$ \\
\hline 16 & $\begin{array}{l}\text { Are changes tracked with a description, rationale, affected } \\
\text { baselines, verification, and acceptance test } \\
\text { documentation? } \\
\text { [Ensure proposed changes are documented, evaluated, } \\
\text { and approved prior to implementation. } \\
\text { Ensure corrections and changes are verified for correct } \\
\text { operation to ensure no side effects were introduced] }\end{array}$ & $\begin{array}{l}\text { LWP-13620 Step 4.5.6.1, } \\
\text { EXH-13620-1, } \\
\text { EXH-13620-2, } \\
\text { EXH-13620-3 } \\
\text { LRD-13600 Step } 3.10 .5 .3 \\
\text { DOE O 414.1C Att } 2 \\
\text { Section 3e, } 5 \text { d(3) } \\
\text { DOE G 414.1-4 App F } \\
\text { Section F.5.3 } \\
\text { NQA-1-2000 Req't 3 Para } \\
802.2\end{array}$ & $\begin{array}{l}\text { 区 Acceptable } \\
\square \text { Unacceptable } \\
\square \text { Not Applicable }\end{array}$ & $\begin{array}{l}\text { Change Management Tool: NS-18211 } \S 8.2 \\
\text { and Attachment A. } \\
\text { Discussion: }\end{array}$ \\
\hline 17 & $\begin{array}{l}\text { What SQA program requirements are subcontractors } \\
\text { required to comply with when performing software } \\
\text { management activities in support of your organization? } \\
\text { [Ensure procurement documents identify technical and } \\
\text { quality requirements and problem reporting to and/from the } \\
\text { supplier. } \\
\text { Ensure acquired software meets requirements with the } \\
\text { appropriate level of QA based on risk, safety etc } \\
\text { Ensure the suppliers' QA program has been } \\
\text { reviewed and meets or exceeds the procurement } \\
\text { specification requirements.] }\end{array}$ & $\begin{array}{l}\text { LWP-13620 Step } 4.2 .2 \\
4.2 .3 \\
\text { LRD-13600, Step } 3.2 .1 \\
\text { DOE O } 414.1 \text { C Att } 2 \\
\text { Section } 3 g, 5 d(4) \\
\text { DOE G } 414.1-4 \text { App F } \\
\text { Section F. } 5.4 \\
\text { NQA-1-2000 Subpart } 2.7 \\
\text { Para } 301,302\end{array}$ & $\begin{array}{l}\square \text { Acceptable } \\
\square \text { Unacceptable } \\
\square \text { Not Applicable }\end{array}$ & $\begin{array}{l}\text { Contract / Agreement: } \\
\text { Discussion: The application uses only } \\
\text { commercial off-the-shelf software, without } \\
\text { modification for INL use. INL } \\
\text { subcontractors do not perform any software } \\
\text { management activities with this application. } \\
\text { Criticality Safety Engineering would revise } \\
\text { NS-18211 to provide appropriate direction if } \\
\text { it decides to use subcontractors for such } \\
\text { activities in the future. }\end{array}$ \\
\hline 18 & What activities are being performed for process & Best Practice & $\triangle$ Acceptable & Discussion: \\
\hline
\end{tabular}




\begin{tabular}{|c|c|c|c|c|}
\hline & Item & Requirement & Results & Objective Evidence \\
\hline & $\begin{array}{l}\text { improvement (e.g., lessons learned, metrics, self- } \\
\text { assessments)? }\end{array}$ & & $\begin{array}{l}\square \text { Unacceptable } \\
\square \text { Not Applicable }\end{array}$ & $\begin{array}{l}\text { - Criticality Safety Engineering recentiy } \\
\text { obtained and tested a second network } \\
\text { attached storage (NAS) device, now } \\
\text { named ramses, to reduce vulnerability } \\
\text { and improve recovery activities. The } \\
\text { V\&V report revisions documenting } \\
\text { successful testing will be completed in } \\
\text { October } 2011 . \\
\text { Criticality Safety Engineering recently } \\
\text { installed, tested, and accepted seven } \\
\text { uninterruptable power supplies to } \\
\text { reduce vulnerability. } \\
\text { The manager, SPM, and STL are } \\
\text { investigating the possibility of having } \\
\text { Information Technology specialists } \\
\text { maintain this application's hardware in } \\
\text { the specialist's secure area. } \\
\text { The SPM and STL seek and assess the } \\
\text { possible impact of information regarding } \\
\text { software package development, } \\
\text { revision, updates, upgrades, and } \\
\text { issues. To this end, they are on } \\
\text { distribution for SQA lessons learned } \\
\text { reports generated within INL and DOE. } \\
\text { They also subscribe to appropriate } \\
\text { vendor (RSICC) and code developer } \\
\text { newsletters and electronic forums for } \\
\text { the application's current software } \\
\text { packages (MCNP and SCALE). } \\
\text { Criticality Safety Engineering personnel } \\
\text { communicate with code developers and } \\
\text { their colleagues at other facilities to } \\
\text { obtain information, advice, and } \\
\text { assistance. Among other things, } \\
\text { personnel learn hardware and software } \\
\text { information that the application owner, } \\
\text { SPM, and STL consider when deciding } \\
\text { to update, upgrade, or assess the } \\
\text { application or to train personnel. } \\
\text { - }\end{array}$ \\
\hline
\end{tabular}


This page intentionally blank 


\section{Criticality Safety ICAMS Issues/Actions}




\section{ICAMS Issues/Observations 2011}

\begin{tabular}{|c|c|c|c|c|c|c|c|}
\hline $\begin{array}{l}\text { Trackin } \\
\text { g } \\
\text { Number }\end{array}$ & Condition or Problem Title & $\begin{array}{l}\text { Date } \\
\text { Identif } \\
\text { ied }\end{array}$ & $\begin{array}{l}\text { Current } \\
\text { Phase }\end{array}$ & $\begin{array}{l}\text { Issue } \\
\text { Type }\end{array}$ & $\begin{array}{l}\text { Significan } \\
\text { ce of } \\
\text { Problem }\end{array}$ & Source Type & Source Title \\
\hline IO-011577 & $\begin{array}{l}\text { Revise the HFEF CHCS (HFEF-OI-1020) to } \\
\text { incorporate Room } 125 \text { Mass Limit CCA into the HFEF } \\
\text { Procedure CCA }\end{array}$ & $6 / 1 / 11$ & Closed & Observation & & $\begin{array}{l}\text { Company : Assessment or } \\
\text { Review }\end{array}$ & CCA Inspection CSI11102 \\
\hline 10-004035 & $\begin{array}{l}\text { The CSO at HFEF and other MFC facilities does not } \\
\text { have adequate resources to perform } \\
\text { roles/responsibilities }\end{array}$ & $8 / 6 / 10$ & $\begin{array}{l}\text { Corrective Action } \\
\text { Implementation }\end{array}$ & Observation & & $\begin{array}{l}\text { Unplanned Observation } \\
\text { (Internally Identified) }\end{array}$ & $\begin{array}{l}\text { Eric Papaioannou's Unplanned } \\
\text { Observations }\end{array}$ \\
\hline IO-014767 & $\begin{array}{l}\text { CCA Inspection at FMF identified need to clarify "no } \\
\text { liquid" control for approved storage and clarify special } \\
\text { reflectors. }\end{array}$ & $8 / 23 / 11$ & $\begin{array}{l}\text { Corrective Action } \\
\text { Implementation }\end{array}$ & Observation & & $\begin{array}{l}\text { Company : } \\
\text { Surveillance/Inspection }\end{array}$ & IAS11702 CCA Inspections \\
\hline $10-008085$ & MTG Conservative Mass Factors May Need Updating & $1 / 4 / 11$ & $\begin{array}{l}\text { Corrective Action } \\
\text { Implementation }\end{array}$ & Observation & Adverse & $\begin{array}{l}\text { Unplanned Observation } \\
\text { (Internally Identified) }\end{array}$ & $\begin{array}{l}\text { Mass Limit Alert from the FCF } \\
\text { Mass Tracking System }\end{array}$ \\
\hline IO-008017 & $\begin{array}{l}\text { Revise 00INL189, "Criticality Safety Principles' web- } \\
\text { based training. }\end{array}$ & $12 / 17 / 10$ & $\begin{array}{l}\text { Corrective Action } \\
\text { Implementation }\end{array}$ & Observation & & $\begin{array}{l}\text { Company : Assessment or } \\
\text { Review }\end{array}$ & $\begin{array}{l}2010 \text { Annual Criticality Safety } \\
\text { Program Performance Summary }\end{array}$ \\
\hline $10-005849$ & $\begin{array}{l}\text { Revise the HFEF CHCS to change the definition of } \\
\text { "moderator" to "liquid moderator" in the next revision. }\end{array}$ & $9 / 14 / 10$ & Closed & Observation & & $\begin{array}{l}\text { Company : Assessment or } \\
\text { Review }\end{array}$ & $\begin{array}{l}\text { Criticality Control Area (CCA) } \\
\text { Annual Inspections }\end{array}$ \\
\hline $10-008380$ & $\begin{array}{l}\text { No assessment has been scheduled in FY11 for the } \\
\text { QL-2 application, Criticality Safety Analysis } \\
\text { application (EA ID: 229224). }\end{array}$ & $12 / 16 / 10$ & Closed & Observation & & $\begin{array}{l}\text { Company : Management } \\
\text { Assessment }\end{array}$ & $\begin{array}{l}\text { Adequacy and Effectiveness of the } \\
\text { Site Wide Implementation of } \\
\text { Software Quality Assurance } \\
\text { Program }\end{array}$ \\
\hline $10-007770$ & $\begin{array}{l}\text { Criticality Safety Engineering should define, or } \\
\text { discontinue INL use of, the phrase "favorable } \\
\text { geometry". }\end{array}$ & $12 / 8 / 10$ & Closed & Observation & & $\begin{array}{l}\text { Company : Assessment or } \\
\text { Review }\end{array}$ & $\begin{array}{l}\text { Review of ATR and ATRC Facility } \\
\text { Criticality Safety Training Materials } \\
\text { - VLP-04-10 }\end{array}$ \\
\hline 1O-007798 & $\begin{array}{l}\text { Criticality Safety Engineering should review LRD- } \\
18001 \text { for the appropriateness of including } \\
\text { "heterogeneity" as a factor to be included in FMH } \\
\text { training. }\end{array}$ & $12 / 8 / 10$ & Closed & Observation & & $\begin{array}{l}\text { Company : Assessment or } \\
\text { Review }\end{array}$ & $\begin{array}{l}\text { Review of ATR and ATRC Facility } \\
\text { Criticality Safety Training Materials } \\
\text { - VLP-04-10 }\end{array}$ \\
\hline IO-005819 & HFEF CSO too busy to perform duties. & $9 / 14 / 10$ & Closed & Observation & & $\begin{array}{l}\text { Unplanned Observation } \\
\text { (Internally Identified) }\end{array}$ & $\begin{array}{l}2010 \text { Annual Criticality Safety } \\
\text { Program Performance Summary }\end{array}$ \\
\hline 10-007763 & $\begin{array}{l}\text { ATRC-specific training is needed that specifically } \\
\text { addresses ATRC safety basis documents, controls, } \\
\text { bases for controls, and criticality accident scenarios } \\
\text { that differ from ATR documents, controls, bases, and } \\
\text { scenarios. }\end{array}$ & $12 / 8 / 10$ & Closed & Observation & & $\begin{array}{l}\text { Company : Assessment or } \\
\text { Review }\end{array}$ & $\begin{array}{l}2010 \text { Annual Criticality Safety } \\
\text { Program Performance Summary }\end{array}$ \\
\hline IO-007808 & $\begin{array}{l}\text { ATR training should review training qualification } \\
\text { criteria lists in TRAIN and the qualification checklist } \\
\text { items on-the-job training and initial qualification } \\
\text { checklists for adequacy. }\end{array}$ & $12 / 8 / 10$ & Closed & Observation & & $\begin{array}{l}\text { Company : Assessment or } \\
\text { Review }\end{array}$ & $\begin{array}{l}2010 \text { Annual Criticality Safety } \\
\text { Program Performance Summary }\end{array}$ \\
\hline $10-008016$ & Revise NS-18202, "Criticality Safety Assessments" & $12 / 17 / 10$ & Closed & Observation & & $\begin{array}{l}\text { Company : Assessment or } \\
\text { Review }\end{array}$ & $\begin{array}{l}2010 \text { Annual Criticality Safety } \\
\text { Program Performance Summary }\end{array}$ \\
\hline IO-012409 & $\begin{array}{l}\text { The Emergency Voice Announcement System at MFC } \\
\text { is Less than Adequate }\end{array}$ & $7 / 11 / 11$ & Open & Observation & Adverse & $\begin{array}{l}\text { Unplanned Observation } \\
\text { (Internally Identified) }\end{array}$ & Initial Notification Report (INR) \\
\hline
\end{tabular}




\section{ICAMS Action Items 2011}

\begin{tabular}{|c|c|c|c|c|c|c|c|c|c|}
\hline $\begin{array}{l}\text { Action } \\
\text { Item } \\
\text { Number }\end{array}$ & $\begin{array}{l}\text { I/O } \\
\text { Number }\end{array}$ & $\begin{array}{l}\text { Responsible } \\
\text { Manager }\end{array}$ & Actionee & $\begin{array}{l}\text { Date } \\
\text { Assign } \\
\text { ed }\end{array}$ & $\begin{array}{l}\text { Due } \\
\text { Date }\end{array}$ & Title & Action Description & Objective Evidence & $\begin{array}{l}\text { Date } \\
\text { Action } \\
\text { Completed }\end{array}$ \\
\hline Al-02546 & $10-004035$ & $\begin{array}{l}\text { W310 - Criticality Safety } \\
\text { Engineering Issues } \\
\text { Management Group }\end{array}$ & J T. Taylor & $11 / 16 / 10$ & $12 / 20 / 11$ & $\begin{array}{l}\text { Strengthen CSO } \\
\text { Program }\end{array}$ & $\begin{array}{l}\text { Interview all CSOs at MFC to verify } \\
\text { understanding of tracking significant } \\
\text { quantities of fissionable material and } \\
\text { discuss pertinent facility specific issues. }\end{array}$ & Letter documenting meetings. & \\
\hline Al-03686 & $10-008017$ & $\begin{array}{l}\text { W310 - Criticality Safety } \\
\text { Engineering Issues } \\
\text { Management Group }\end{array}$ & $\begin{array}{l}\text { Valerie L. } \\
\text { Putman } \\
\end{array}$ & 2/23/11 & $6 / 30 / 12$ & $\begin{array}{l}\text { Revise 00INL189 } \\
\text { "Criticality Safety } \\
\text { Principles" web- } \\
\text { based training } \\
\end{array}$ & $\begin{array}{l}\text { Revise 0OINL } 189 \text { "Criticality Safety } \\
\text { Principles" web-based training with } \\
\text { improvements to strengthen fissionable } \\
\text { material handler training. }\end{array}$ & $\begin{array}{l}\text { Launch new version of } \\
\text { "Criticality Safety Principles" } \\
\text { web-based training. }\end{array}$ & \\
\hline Al-05417 & IO-011577 & $\begin{array}{l}\text { W310 - Criticality Safety } \\
\text { Engineering Issues } \\
\text { Management Group }\end{array}$ & $\begin{array}{l}\text { Charles E. } \\
\text { Stuart }\end{array}$ & $7 / 22 / 11$ & 9/30/11 & $\begin{array}{l}\text { Revise the HFEF } \\
\text { CHCS }\end{array}$ & $\begin{array}{l}\text { Revise the HFEF CHCS to include Room } \\
125 .\end{array}$ & $\begin{array}{l}\text { Room } 125 \text { will be absorbed } \\
\text { into the HFEF Procedure } \\
\text { CCA and eliminated as a } \\
\text { Mass Limit CCA on the } 2011 \\
\text { Master CCA List. }\end{array}$ & $11 / 8 / 11$ \\
\hline Al-06348 & IO-008017 & $\begin{array}{l}\text { W310 - Criticality Safety } \\
\text { Engineering Issues } \\
\text { Management Group }\end{array}$ & J T. Taylor & 10/17/11 & $3 / 31 / 12$ & $\begin{array}{l}\text { Revise Study } \\
\text { Guide INL/EXT-06- } \\
01183\end{array}$ & $\begin{array}{l}\text { Revise Study Guide INL/EXT-06-01183, } \\
\text { "Criticality Safety Basics for INL FMHs and } \\
\text { CSOs" }\end{array}$ & $\begin{array}{l}\text { Provide draft copy of } \\
\text { document to EDMS }\end{array}$ & \\
\hline $\mathrm{Al}-06349$ & $10-014767$ & $\begin{array}{l}\text { W310 - Criticality Safety } \\
\text { Engineering Issues } \\
\text { Management Group }\end{array}$ & J. T. Taylor & $10 / 17 / 11$ & $12 / 23 / 11$ & $\begin{array}{l}\text { Issue CSE that } \\
\text { defines special } \\
\text { reflectors }\end{array}$ & $\begin{array}{l}\text { Issue criticality safety evaluation that } \\
\text { defines special reflectors }\end{array}$ & $\begin{array}{l}\text { eCR report submitted to } \\
\text { EDMS }\end{array}$ & $11 / 10 / 11$ \\
\hline Al-06350 & IO-014767 & $\begin{array}{l}\text { W310 - Criticality Safety } \\
\text { Engineering Issues } \\
\text { Management Group }\end{array}$ & J T. Taylor & 10/17/11 & $2 / 28 / 12$ & $\begin{array}{l}\text { Provide a draft of } \\
\text { revised LST-386 to } \\
\text { Operations }\end{array}$ & $\begin{array}{l}\text { Provide a draft of revised LST-386, "Fuel } \\
\text { Manufacturing Facility Criticality Control } \\
\text { List", to Operations to incorporate special } \\
\text { reflector definition and resolution to "no } \\
\text { liquids" definition. }\end{array}$ & $\begin{array}{l}\text { Revised draft copy of LST- } \\
386\end{array}$ & \\
\hline Al-06371 & $10-008017$ & $\begin{array}{l}\text { W310 - Criticality Safety } \\
\text { Engineering Issues } \\
\text { Management Group }\end{array}$ & $\begin{array}{l}\text { Andrea B. } \\
\text { Hoffman }\end{array}$ & $10 / 17 / 11$ & $3 / 31 / 12$ & $\begin{array}{l}\text { Revise INL/EXT- } \\
06-01183\end{array}$ & $\begin{array}{l}\text { Review LRD-18001 for the } \\
\text { appropriateness of including } \\
\text { "heterogeneity" as a factor to be included } \\
\text { in FMH training. }\end{array}$ & $\begin{array}{l}\text { Revise Section } 4.1 .7 \text { in } \\
\text { INL/EXT-06-01183 "Criticality } \\
\text { Safety Basics for INL FMHs } \\
\text { and CSOs" and address the } \\
\text { terms "homogeneity" and } \\
\text { "heterogeneity" }\end{array}$ & \\
\hline Al-04855 & $10-008085$ & $\begin{array}{l}\text { GC00- INL MFC } \\
\text { Nuclear Operations }\end{array}$ & $\begin{array}{l}\text { P. J. } \\
\text { Sentieri }\end{array}$ & $5 / 27 / 11$ & 9/30/11 & $\begin{array}{l}\text { Complete a TEV on } \\
\text { the MkV } \\
\text { Electrorefiner }\end{array}$ & $\begin{array}{l}\text { Complete a TEV/ECAR that provides a } \\
\text { basis to establish a value for the plutonium } \\
\text { in the MK-V ER based upon the analytical } \\
\text { data and process knowledge that will allow } \\
\text { the return of two batches of condensate. }\end{array}$ & Attach TEV & $11 / 2 / 11$ \\
\hline Al-005740 & $10-009673$ & $\begin{array}{l}\text { GC00- INL MFC } \\
\text { Nuclear Operations }\end{array}$ & $\begin{array}{l}\text { Andrea B. } \\
\text { Hoffman }\end{array}$ & $8 / 24 / 11$ & $7 / 2 / 12$ & $\begin{array}{l}\text { Revise LRD-18001 } \\
\text { for clarification } \\
\text { periodic verification } \\
\text { of CAS }\end{array}$ & $\begin{array}{l}\text { Review ANSI Series } 8 \text { standards for CAS } \\
\text { requirements and discuss issue with J. T. } \\
\text { Taylor and the FMF cognizant system } \\
\text { engineer (Charlie Lahm) }\end{array}$ & $\begin{array}{l}\text { Revise LRD-18001 to clarify } \\
\text { requirements for periodic } \\
\text { testing of the entire FMF } \\
\text { CAS. Provide any follow-on } \\
\text { recommendations to revise } \\
\text { MFC FMF CAS Testing } \\
\text { procedures, as applicable, to } \\
\text { the CSE. }\end{array}$ & \\
\hline Al-003737 & IO-008016 & $\begin{array}{l}\text { W310 - Criticality Safety } \\
\text { Engineering Issues } \\
\text { Management Group }\end{array}$ & $\begin{array}{l}\text { Andrea B. } \\
\text { Hoffman }\end{array}$ & $12 / 17 / 10$ & 9/1/11 & $\begin{array}{l}\text { Revise NS-18202 } \\
\text { "Criticality Safety } \\
\text { Assessments" }\end{array}$ & $\begin{array}{l}\text { Laboratory assessment procedures have } \\
\text { significantly changed and NS-18202 has } \\
\text { not been revised since } 2006 \text {. }\end{array}$ & Revised procedure on EDMS. & 10/17/11 \\
\hline
\end{tabular}




\section{ICAMS Action Items 2011 (continued)}

\begin{tabular}{|c|c|c|c|c|c|c|c|c|c|}
\hline $\begin{array}{l}\text { Action } \\
\text { Item } \\
\text { Number }\end{array}$ & $\begin{array}{l}\text { I/O } \\
\text { Number }\end{array}$ & $\begin{array}{l}\text { Responsible } \\
\text { Manager }\end{array}$ & Actionee & $\begin{array}{l}\text { Date } \\
\text { Assign } \\
\text { ed }\end{array}$ & $\begin{array}{l}\text { Due } \\
\text { Date }\end{array}$ & Title & Action Description & Objective Evidence & $\begin{array}{l}\text { Date } \\
\text { Action } \\
\text { Completed }\end{array}$ \\
\hline $\mathrm{Al}-02543$ & 10-004035 & $\begin{array}{l}\text { W310 - Criticality Safety } \\
\text { Engineering Issues } \\
\text { Management Group }\end{array}$ & $\begin{array}{l}\text { Andrea B. } \\
\text { Hoffman }\end{array}$ & $11 / 16 / 10$ & $11 / 3 / 10$ & $\begin{array}{l}\text { Modify/strengthen } \\
\text { Criticality Safety } \\
\text { Officer Training }\end{array}$ & $\begin{array}{l}\text { The Facility Familiarization Form for the } \\
\text { CSO qualification process has been } \\
\text { revised to include an approval sign-off of } \\
\text { the Criticality Safety Manager. }\end{array}$ & $\begin{array}{l}\text { Revised NS-18204, } \\
\text { "Criticality Safety Officer } \\
\text { Qualification Plan" (rev. 3) } \\
\text { issued on EDMS. }\end{array}$ & $11 / 3 / 10$ \\
\hline $\mathrm{Al}-02547$ & 10-004035 & $\begin{array}{l}\text { W310 - Criticality Safety } \\
\text { Engineering Issues } \\
\text { Management Group }\end{array}$ & J T. Taylor & $11 / 16 / 10$ & $7 / 1 / 11$ & $\begin{array}{l}\text { Strengthen CSO } \\
\text { Program }\end{array}$ & $\begin{array}{l}\text { Resolve the CSO inadequacy issues at } \\
\text { FCF and HFEF. }\end{array}$ & $\begin{array}{l}\text { JTT letter documenting } \\
\text { results. }\end{array}$ & $9 / 26 / 11$ \\
\hline $\mathrm{Al}-02542$ & IO-005849 & $\begin{array}{l}\text { W310 - Criticality Safety } \\
\text { Engineering Issues } \\
\text { Management Group }\end{array}$ & $\begin{array}{l}\text { Charles E. } \\
\text { Stuart }\end{array}$ & $11 / 16 / 10$ & $5 / 31 / 11$ & $\begin{array}{l}\text { Revise HFEF } \\
\text { CHCS }\end{array}$ & $\begin{array}{l}\text { Revise HFEF CHCS to change the } \\
\text { definition of "moderator" to "liquid } \\
\text { moderator" in the next revision. }\end{array}$ & $\begin{array}{l}\text { Copy of the revised CHCS on } \\
\text { EDMS }\end{array}$ & $5 / 24 / 11$ \\
\hline Al-03687 & IO-008428 & $\begin{array}{l}\text { W310 - Criticality Safety } \\
\text { Engineering Issues } \\
\text { Management Group }\end{array}$ & $\begin{array}{l}\text { V. L. } \\
\text { Putman }\end{array}$ & $2 / 23 / 11$ & $6 / 1 / 11$ & $\begin{array}{l}\text { Develop new } \\
\text { criticality safety } \\
\text { training for SSPSF. }\end{array}$ & $\begin{array}{l}\text { Review criticality safety training developed } \\
\text { to implement new DSA for SSPSF. }\end{array}$ & $\begin{array}{l}\text { New training developed to } \\
\text { implement new controls } \\
\text { contained in revised DSA for } \\
\text { SSPSF. }\end{array}$ & $4 / 21 / 11$ \\
\hline Al-04790 & IO-007808 & $\begin{array}{l}\text { GB61 - Veryl Kirkpatrick } \\
\text { Issues Management } \\
\text { Group }\end{array}$ & Skeen Blair & 10/27/11 & $11 / 30 / 11$ & $\begin{array}{l}\text { Ensure SD-11.1.25, } \\
\text { PDD-105 and qual } \\
\text { checklists } \\
\text { adequately include } \\
\text { criticality safety } \\
\text { training } \\
\text { requirements. }\end{array}$ & $\begin{array}{l}\text { Review ATR Operations qualification } \\
\text { checklists to ensure they meet } \\
\text { requirements for Criticality Safety training. } \\
\text { Review the training qual paths (TRAIN) for } \\
\text { the various ATR operations positions to } \\
\text { ensure they meet criticality safety training } \\
\text { requirements. }\end{array}$ & $\begin{array}{l}\text { Lotus notes email to Issues } \\
\text { Management documenting } \\
\text { the results of the review. }\end{array}$ & $11 / 15 / 11$ \\
\hline Al-04791 & 10-007763 & $\begin{array}{l}\text { GB61 - Veryl Kirkpatrick } \\
\text { Issues Management } \\
\text { Group }\end{array}$ & Skeen Blair & 10/27/11 & $12 / 15 / 11$ & $\begin{array}{l}\text { Develop an ATRC } \\
\text { specific criticality } \\
\text { safety lesson plan } \\
\text { similar in scope to } \\
\text { ATR Criticality } \\
\text { Safety Lesson Plan } \\
\text { TRA00013. } \\
\end{array}$ & $\begin{array}{l}\text { Include a discussion on SAR/TSR-192 } \\
\text { criticality controls and bases for the } \\
\text { controls. Discuss the various accident } \\
\text { scenarios, their associated controls and } \\
\text { bases. }\end{array}$ & $\begin{array}{l}\text { Complete and approve the } \\
\text { lesson plan to issues } \\
\text { management. }\end{array}$ & $11 / 15 / 11$ \\
\hline Al-01932 & IO-005496 & $\begin{array}{l}\text { W310 - Criticality Safety } \\
\text { Engineering Issues } \\
\text { Management Group }\end{array}$ & $\begin{array}{l}\text { V. L. } \\
\text { Putman }\end{array}$ & $10 / 6 / 10$ & $12 / 31 / 10$ & $\begin{array}{l}\text { ATR/ATRC facility } \\
\text { criticality safety } \\
\text { training } \\
\text { review/assessment }\end{array}$ & $\begin{array}{l}\text { Review ATR and ATRC facility criticality } \\
\text { safety training materials and provide } \\
\text { consolidated criticality scenarios if } \\
\text { necessary. }\end{array}$ & $\begin{array}{l}\text { E-mail or report detailing the } \\
\text { results of the review. }\end{array}$ & $12 / 10 / 10$ \\
\hline $\mathrm{Al}-06360$ & IO-012409 & $\begin{array}{l}\text { GC83-Fuel Mgmt Dept } \\
\text { Issues Management } \\
\text { Group }\end{array}$ & J. T. Taylor & 10/17/11 & $1 / 31 / 12$ & $\begin{array}{l}\text { Evaluate EAR/EAL } \\
\text { for Criticality at } \\
\text { MFC }\end{array}$ & $\begin{array}{l}\text { For a criticality at MFC, 1) Evaluate the } \\
\text { EAL against facility EAR's for consistency, } \\
\text { 2) Correct the EAL (if required) and } \\
\text { provide guidance to revise facility } \\
\text { EARs/ONRIs to provide consistency for a } \\
\text { criticality at MFC. }\end{array}$ & $\begin{array}{l}\text { JTT-03-2011 "Response to } \\
\text { Criticality Alarms at MFC" }\end{array}$ & $12 / 8 / 11$ \\
\hline
\end{tabular}


This page intentionally blank 


\section{Criticality Safety Infractions CY-2011}

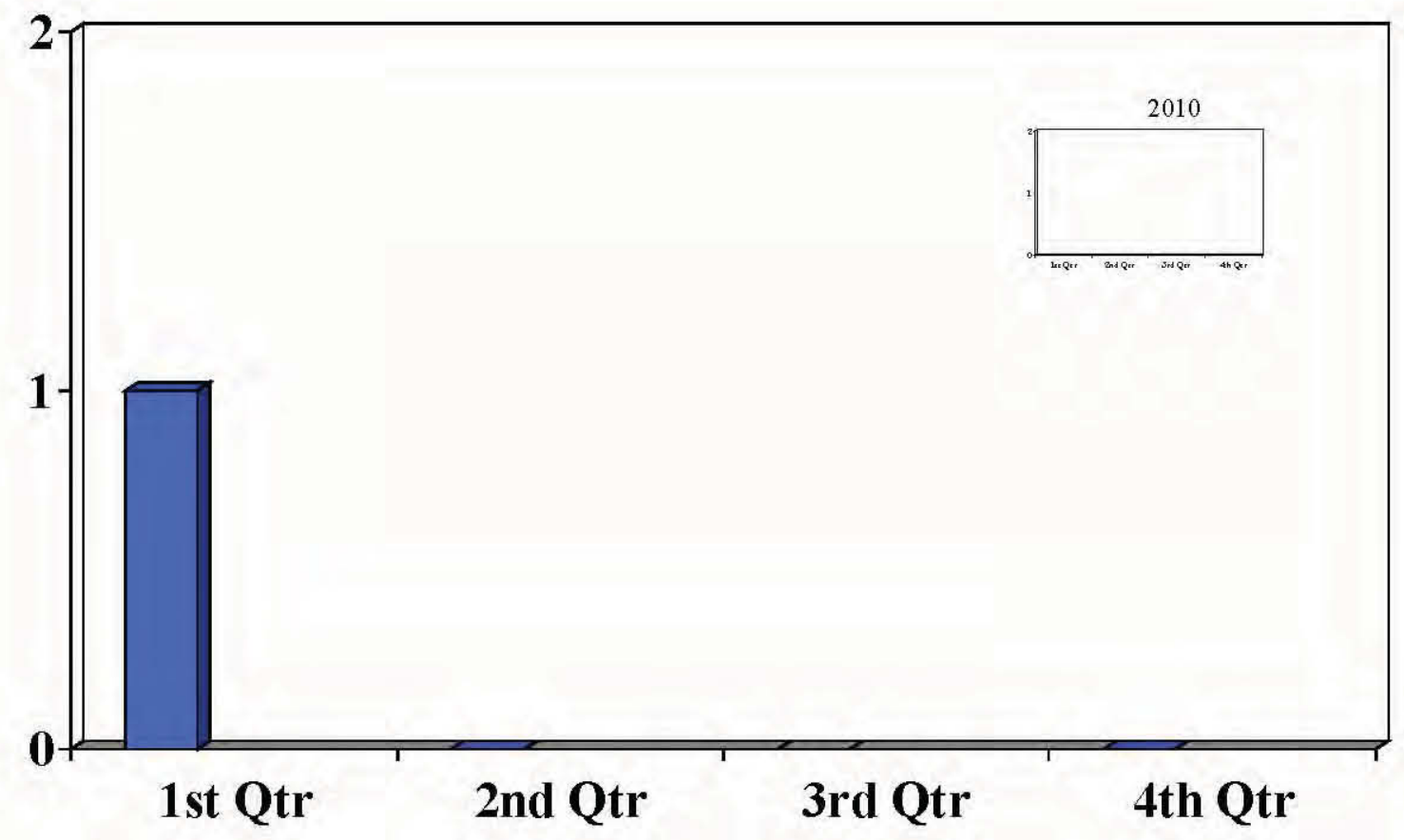

On January 18,2011 , it was discovered that a fuel plate in the Nuclear Materials Inspection and Storage (NMIS) facility exceeded the fissionable mass limit, resulting in a technical safety requirement (TSR) violation The TSR limits fuel plate bundles to 1085 grams U-235, which is the maximum loading of an ATR fuel element. The fuel plate bundle contained $107 \mathrm{~g} \mathrm{U}-235$ and was assembled under a $1100 \mathrm{~g} \mathrm{U}-235$ limit in 1982 at INTEC (CPP-651). In 2003, the limit was reduced to $1085 \mathrm{~g}$ using a new criticality safety evaluation for ATR fuels. The fuel plate bundle inventories were not checked for compliance prior to implementing the reduced limit. A subsequent review of the NMIS inventory did not identify further violations. 


\section{Criticality Safety Infractions CY-2010}

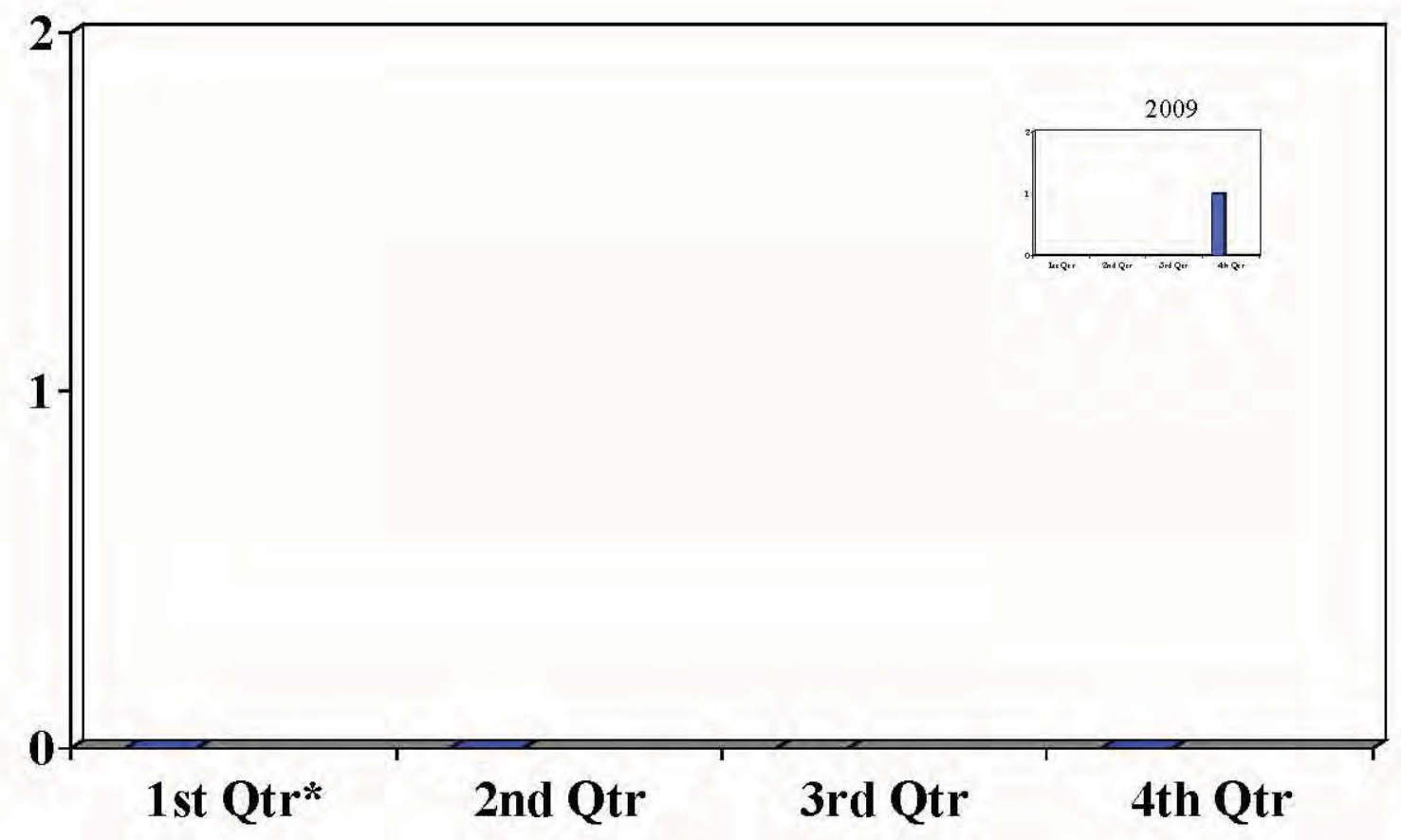

* On both January 21 and January 25, 2010, technical safety requirement violations occurred at the Radioactive Scrap and Waste Facility (RSWF) at the Materials and Fuels Complex (MFC). The violations involved Remote Handled Transuranic (RH-TRU) waste retrieval operations. During the retrieval of a waste canister, personnel failed to stop work when identification markings on the side of two waste canisters did not match the markings on the top of the canisters or on the list of containers approved for retrieval. The verification control is in place to ensure that only those waste canisters approved for transfer are removed and transferred. Subsequent investigation determined that the waste canisters in question had been analyzed and were approved for retrieval. 


\section{Occurrence Report NE-ID-BEA-ATR-2011-0003 "Nuclear Materials Inspection and Storage (NMIS) Facility Fuel Storage Safety Analysis Report (SAR)-154 \\ Administrative Control Limit Exceeded"}


This page intentionally blank 
NE-ID--BEA-ATR-2011-0003

NOTIFICATION

\section{Occurrence Report}

After 2003 Redesign

Advanced Test Reactor

(Name of Facility)

Category "A" Reactors

(Facility Function)

Idaho National Laboratory

Battelle Energy Alliance, LLC

(Site) (Contractor)

Name: SCHUEBERT, EDMOND J

Title: ATR Operations Facility Manager

Telephone No.: (208) 533-4246

(Facility Manager/Designee)

Name: OWENS, MARJORIE A

Title: ATR OPERATIONS FACILITY ADMINISTRATI

Telephone No.: (208) 533-4563

(Originator/Transmitter)

Name: E. Bruce Criswell

Date: $01 / 19 / 2011$

(Authorized Classifier (AC))

1. Occurrence Report Number: NE-ID--BEA-ATR-2011-0003

Nuclear Materials Inspection and Storage (NMIS) Facility Fuel Storage Safety Analysis Report (SAR)-154 Administrative Control Limit Exceeded

2. Report Type and Date: NOTIFICATION

\begin{tabular}{|l|l|l|}
\hline & Date & Time \\
\hline Notification: & $01 / 19 / 2011$ & $18: 56($ ETZ) \\
\hline Initial Update: & & (ETZ) \\
\hline Latest Update: & & (ETZ) \\
\hline Final: & & (ETZ) \\
\hline
\end{tabular}

\section{Significance Category: 2}

4. Division or Project: ATR Programs

5. Secretarial Office: NE - Nuclear Energy, Science and Technology 
6. System, Bldg., or Equipment: Nuclear Materials Inspection and Storage (NMIS)

7. UCNI?: No

8. Plant Area: NMIS

9. Date and Time Discovered: $\quad 01 / 17 / 2011 \quad 16: 53$ (MTZ)

10. Date and Time Categorized: $\quad 01 / 18 / 2011 \quad 18: 20$ (MTZ)

11. DOE HQ OC Notification:

\begin{tabular}{|l|l|l|l|}
\hline Date & Time & Person Notified & Organization \\
\hline NA & NA & NA & NA \\
\hline
\end{tabular}

\section{Other Notifications:}

\begin{tabular}{|l|l|l|l|}
\hline Date & Time & Person Notified & Organization \\
\hline $01 / 18 / 2011$ & $\begin{array}{l}20: 00 \\
(\text { MTZ) }\end{array}$ & B. Boston & DOE-ID \\
\hline
\end{tabular}

\section{Subject or Title of Occurrence:}

Nuclear Materials Inspection and Storage (NMIS) Facility Fuel Storage Safety Analysis Report (SAR)-154 Administrative Control Limit Exceeded

\section{Reporting Criteria:}

$3 \mathrm{~A}(2)$ - Any violation or noncompliance of a Hazard Category 1, 2, or 3 nuclear facility's Technical Safety Requirement (or Operational Safety Requirement) Limiting Control Setting, Limiting Condition for Operation, Administrative Control, or Surveillance Requirement.

Exception: An event consisting solely of a surveillance test performed after the prescribed surveillance period, and in which the equipment was found to be capable of performing its specified safety function. (See separate criterion for late surveillance tests below).

\section{Description of Occurrence:}

On January 17, 2011, a Criticality Safety Engineer was performing a review of the NMIS fuel storage inventory in support of the next NMIS SAR update. After summing the data of fuel plates stored in one location, a discrepancy was noted between the inventory data and the approved fuel list (SAR-154-6A) requirements. This potential issue was reported to the Facility Manager at 1653. 
At 1330 on January 18, 2011, the Facility Manager entered the NMIS to review the NMIS fuel storage database. This is a different database than the one reviewed by the engineer at a different location. It was verified that one bundle of Advanced Test Reactor (ATR) fuel element plates appears to have more than the allowed amount of fuel in this configuration.

SAR-154-6A, Revs. 0 (April 2003) through 6 (March 2010), specify a maximum number of plates containing a maximum quantity of fuel which is less than the value used prior to this SAR revision. If plates of more than one size number are included, they must be in their nested order. The cited Criticality Safety Evaluation (CSE) model ATR fuel with a maximum quantity of fuel per element based on the element design specifications.

The plates arrived at the Idaho National Laboratory (INL) from Rockwell International (Canoga Park, CA) in December 1982. It is likely that these plates have been in the same bundle since receipt because, with the exception of their plate size numbers, the sequential plate serial numbers indicate they belong in the same element, had fabrication reached that stage. It is not known who assembled this particular bundle (NMIS personnel, Chemical Processing Plant (CPP) personnel, or the shipper) or when. The fuel plates were stored at a storage facility at a different site location during the NMIS vault modification which allowed a higher fuel limit.

NMIS preparations to take back the fuel from CPP-651 included changing NMIS limits to be consistent with CPP-651 limits for plate-bundles. (SAR-36, Rev. 2, March 1990). The operational safety requirements (OSR) did not change with respect to the fuel limit afterwards. SAR-36, the NMIS SAR which predates NMIS SAR 154, refers to a higher fuel limit in some manner in each of its revisions since 1997. DOP 7.11.4, Rev. 1 (April 1997), required personnel assembling plate-bundles verify compliance with OSR mass limits, which it quotes.

The implementation of SAR-154-6A, Rev. 0 in April 2003 did not include a requirement to verify mass limits of all fuel storage locations in the NMIS to comply with the new CSE model and reduced fuel gram limit.

\section{Is Subcontractor Involved? No}

\section{Operating Conditions of Facility at Time of Occurrence:}

Normal conditions at NMIS facility.

\section{Activity Category:}

03 - Normal Operations (other than Activities specifically listed in this Category)

\section{Immediate Actions Taken and Results:}

Appropriate levels of BEA management and DOE-ID were notified of this event. 
Declared a Technical Safety Requirement (TSR) violation of TSR-154 specific administrative control 5.154.1.

A critique of this event is planned during the week of 24 January 2011.

\section{ISM:}

\section{Cause Code(s):}

\section{Description of Cause:}

23. Evaluation (by Facility Manager/Designee):

24. Is Further Evaluation Required?: No

25. Corrective Actions

Local Tracking System Name: ICAMS

26. Lessons Learned:

27. Similar Occurrence Report Numbers:

28. User-defined Field \#1:

GB10

29. User-defined Field \#2:

\section{HQ Keyword(s):}

01C--Inadequate Conduct of Operations - Violation of Authorization Basis Elements

01J--Inadequate Conduct of Operations - Criticality Procedure Noncompliance

12L--EH Categories - Nuclear Criticality Safety Concern

14E--Quality Assurance - Work Process Deficiency

\section{HQ Summary:}


On January 17, 2011, a Criticality Safety Engineer was performing a review of the NMIS fuel storage inventory in support of the next NMIS SAR update when, after summing the data of fuel plates stored in one location, a discrepancy was noted between the inventory data and the approved fuel list (SAR-154-6A) requirements. This potential issue was reported to the Facility Manager. On January 18, the Facility Manager entered the NMIS to review the NMIS fuel storage database. This is a different database than the one reviewed by the engineer at a different location. It was verified that one bundle of Advanced Test Reactor (ATR) fuel element plates appears to have more than the allowed amount of fuel in this configuration. A Technical Safety Requirement (TSR) violation of TSR-154 specific administrative control 5.154.1 was declared. A critique of this event is planned during the week of January 24.

32. DOE Facility Representative Input:

\section{DOE Program Manager Input:}

(tab) 
This page intentionally blank 


\section{Source Requirement Documents in LRD-18001 (2011)}

10 CFR, Section 830.204 Nuclear Safety Management

ANSI/ANS-8.1,1998, (R2007), “Nuclear Criticality Safety in Operations with Fissionable Materials Outside Reactors"

ANSI/ANS-8.3-1997, (R2003), "Criticality Accident Alarm System”

ANSI/ANS-8.5-1996, (R2002), "Use of Borosilicate-Glass Raschig Rings as a Neutron Absorber in Solutions of Fissile Material"

ANSI/ANS-8.6-1983, (R1988) (R1995), (R2001), "Safety in Conducting Subcritical NeutronMultiplication Measurements in Situ"

ANSI/ANS-8.7-1998, "Guide for Nuclear Criticality Safety in the Storage of Fissile Materials"

ANSI/ANS-8.10-1983 (R1988) (R1999) (R2005), “Criteria for Nuclear Criticality Safety

Controls in Operations with Shielding and Confinement"

ANSI/ANS-8.12-1987, (R2002), "Nuclear Criticality Control and Safety of Plutonium-Uranium Fuel Mixtures Outside Reactors"

ANSI/ANS-8.14-2004, "Use of Soluble Neutron Absorbers in Nuclear Facilities Outside Reactors

ANSI/ANS-8.15-1981, (R1987) (R1995), (R2005), "Nuclear Criticality Control of Special Actinide Elements"

ANSI/ANS-8.17-2004, "Criticality Safety Criteria for the Handling, Storage and Transportation of LWR Fuel Outside Reactors"

ANSI/ANS-8.19-2005,” Administrative Practices for Nuclear Criticality Safety”

ANSI/ANS-8.20-1991, (R1999) (R2005), "Nuclear Criticality Safety Training”

ANSI/ANS-8.21-1995, (R2001),'Use of Fixed Neutron Absorbers in Nuclear Facilities Outside Reactors"

ANSI/ANS-8.22-1997, "Nuclear Criticality Safety Based on Limiting and Controlling Moderators"

ANSI/ANS-8.23-1997, "Nuclear Criticality Accident Emergency Planning and Response”

ANSI/ANS-8.24-2007, "Validation of Neutron Transport Methods for Nuclear Criticality Safety Calculations"

ANSI/ANS-8.26-2007, “Criticality Safety Engineer Training and Qualification Program” 
DOE Order 420.1B, "Facility Safety," Chapter III "Nuclear Criticality Safety," 12-22-06

DOE Order 5480.19, "Conduct of Operations Requirements for DOE Facilities," Change 2, 10-23-01

DOE-STD-1135-99, "Guidance for Nuclear Criticality Safety Engineer Training and Qualification,” September 1999

DOE-STD-3007-2007, “Guidelines for Preparing Criticality Safety Evaluations at Department of Energy Non-Reactor Nuclear Facilities,” February 2007

NS-18211, "Criticality Safety Analysis Software,” October 2010

INL/INT-10-19661, "MCNP5 1.51 Verification and Validation for the Criticality Safety Analysis Software Application," October 2011

INL/INT-10-19660, "MCNP5 1.40 Verification and Validation for the Safety Analysis Software Application," October 2011

INL/INT-11-22236, "SCALE 6.0 Verification and Validation for the Criticality Safety Analysis Software Application," November 2011 
Idaho National Laboratory

\begin{tabular}{c|lll|} 
CHAPTER 6 - PREVENTION OF & Identifier: & SAR-400 & \\
INADVERTENT CRITICALITY - INL & Revision: & 4 & \\
STANDARDIZED SAFETY ANALYSIS & Effective Date: & $05 / 17 / 11$ & Page: 6-1 of 6-10 \\
REPORT & & & \\
\hline
\end{tabular}

\section{CHAPTER 6}

\section{PREVENTION OF INADVERTENT CRITICALITY}


Idaho National Laboratory

\begin{tabular}{c|lll|} 
CHAPTER 6 - PREVENTION OF & Identifier: & SAR-400 \\
INADVERTENT CRITICALITY - INL & Revision: & 4 & \\
STANDARDIZED SAFETY ANALYSIS & Effective Date: & $05 / 17 / 11$ & Page: 6-2 of 6-10 \\
REPORT & & & \\
\hline
\end{tabular}

INTENTIONALLY BLANK 
Idaho National Laboratory

\begin{tabular}{|c|lll|} 
CHAPTER 6 - PREVENTION OF & Identifier: & SAR-400 & \\
INADVERTENT CRITICALITY - INL & Revision: & 4 & \\
STANDARDIZED SAFETY ANALYSIS & Effective Date: & $05 / 17 / 11$ & Page: $6-3$ of 6-10 \\
REPORT & & & \\
\hline
\end{tabular}

CONTENTS

6. PREVENTION OF INADVERTENT CRITICALITY ….......................................................

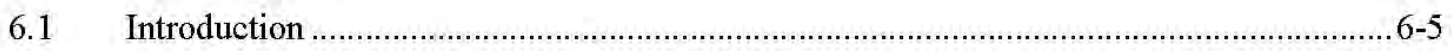

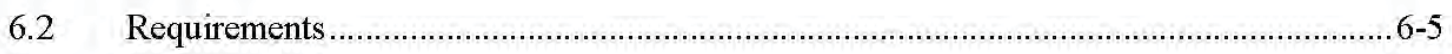

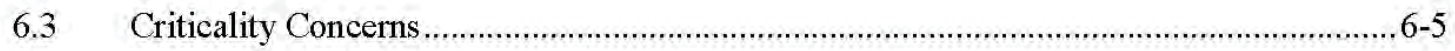

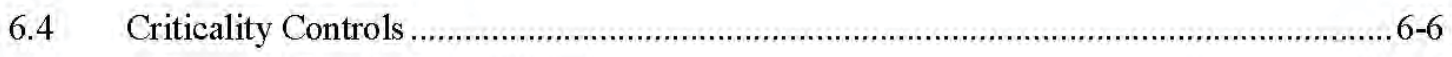

6.4.1 Engineered Controls ..............................................................................6-6

6.4.2 Administrative Controls ............................................................................ $6-7$

6.4.3 Application of Double Contingency Principle ............................................. 6-7

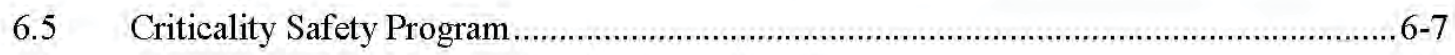

6.5.1 Criticality Safety Organization ………......................................................

6.5.2 Criticality Safety Plans and Procedures ....................................................6-8

6.5.3 Criticality Safety Training ….............................................................. $6-9$

6.5.4 Determination of Operational Nuclear Criticality Limits .............................. 6-9

6.5.5 Criticality Safety Inspections and Audits................................................. 6-9

6.5.6 Criticality Infraction Reporting and Follow-up ........................................... 6-9

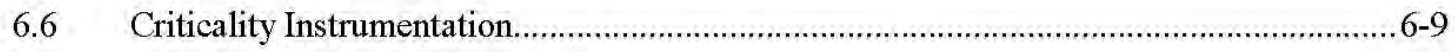

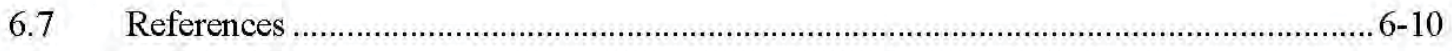


Idaho National Laboratory

\begin{tabular}{c|lll|} 
CHAPTER 6 - PREVENTION OF & Identifier: & SAR-400 \\
INADVERTENT CRITICALITY - INL & Revision: & 4 & \\
STANDARDIZED SAFETY ANALYSIS & Effective Date: & $05 / 17 / 11$ & Page: 6-4 of 6-10 \\
REPORT & & & \\
\hline
\end{tabular}

INTENTIONALLY BLANK 
Idaho National Laboratory

\begin{tabular}{|c|lll|}
\hline CHAPTER 6 - PREVENTION OF & Identifier: & SAR-400 & \\
INADVERTENT CRITICALITY - INL & Revision: & 4 & \\
STANDARDIZED SAFETY ANALYSIS & Effective Date: & $05 / 17 / 11$ & Page: 6-5 of 6-10 \\
REPORT & & & \\
\hline
\end{tabular}

\section{PREVENTION OF INADVERTENT CRITICALITY}

\subsection{Introduction}

This chapter describes the INL Criticality Safety program. The purpose of the Criticality Safety program is to ensure appropriate actions are taken to prevent, and to mitigate the consequences of, a criticality accident. The requirements and recommendations of the Criticality Safety program are documented in Laboratory Requirements Document (LRD)-18001, "INL Criticality Safety Program Requirements Manual,"1 and apply to all INL operations that contain or handle fissionable materials that pose a criticality accident hazard, with the exception of fissionable material in nuclear reactor cores, which is exempt.

\subsection{Requirements}

The following regulations, DOE orders, and industry standards apply to this chapter.

- 10 CFR 830, "Nuclear Safety Management"2

- $\quad$ DOE O 420.1B, Chapter III, "Nuclear Criticality Safety"3

- DOE-STD-3007-2007, "Guidelines for Preparing Criticality Safety Evaluations at Department of Energy Non-Reactor Nuclear Facilities"4

- $\quad$ American National Standards Institute/American Nuclear Society (ANSI/ANS) 8 Series Standards. ${ }^{5}$

Note that this chapter constitutes the INL Criticality Safety Program Deseription Document required by DOE O 420.1B Chapter III, Section 3.a.(3).

\subsection{Criticality Concerns}

The Criticality Safety program requires that criticality safety analysis be performed, with input from operations and other knowledgeable individuals, to document that a process will be subcritical under both normal and credible abnormal conditions before handling fissionable material in a facility or operation, or starting a new operation (including an existing operation that has been changed). Analyses are performed according to DOE-STD-3007-2007 and are governed by Laboratory procedures. The program also requires that the analysis identify the controlled parameters and the limits on these parameters. Discussion of the fissionable material available within a facility, including information on fissionable material form (e.g., chemical and/or physical, including isotopic content, concentration, densities), the location of potential criticality hazards (e.g., description, drawing), and maximum quantities involved, all of which form the basis of the criticality safety analyses, is provided in facility-specific safety basis documentation. 
Idaho National Laboratory

\begin{tabular}{|c|lll|}
\hline CHAPTER 6 - PREVENTION OF & Identifier: & SAR-400 & \\
INADVERTENT CRITICALITY - INL & Revision: & 4 & \\
STANDARDIZED SAFETY ANALYSIS & Effective Date: & $05 / 17 / 11$ & Page: 6-6 of 6-10 \\
REPORT & & & \\
\hline
\end{tabular}

\subsection{Criticality Controls}

The INL Criticality Safety program uses a tiered approach to criticality control. Passive engineered controls, such as geometry control, are the preferred control method. Where passive engineered controls are not feasible, the preferred order of controls is active engineered controls, followed by administrative controls. In addition, the double contingency principle is applied to criticality accident scenarios to determine the required design features and administrative controls needed to prevent an inadvertent criticality.

Criticality controls are derived in accordance with Laboratory procedures. The procedures, which implement DOE-STD-3007-2007, require that criticality safety evaluations (CSEs) be reviewed and approved by safety analysis and line management personnel to ensure that the correct configurations were evaluated and that the derived limits and controls can be implemented. Other organizations, such as emergency preparedness, and engineering, may also be included in the review process.

CSEs provide the documented evaluation of facility activities and equipment involving fissionable material to establish a basis for criticality safety. As such, CSEs identify the engineered and/or administrative controls, and contingencies, necessary to ensure the consequences of criticality accidents are prevented and/or mitigated.

Chapter 6 of the facility-specific DSA presents an overview of the results of the applicable CSEs. The controls necessary to prevent and mitigate the criticality scenarios are evaluated in the facilityspecific hazard/accident analysis to identify those controls that require selection as a technical safety requirement or a safety structure, system, and component (SSC). Factors such as: (1) engineered features that may themselves prevent criticality, (2) scenarios under single parameter administrative control, (3) system complexity, and (4) margin of sub-criticality, are considered in the selection process. Criticality controls may be specifically identified and described in the facility DSA and associated technical safety requirements, or they may be described in a more general manner in the facility DSA/TSRs, with specific details presented in a TSR-required contractor-approved list. When implemented through a contractor-approved list, the list will reference the CSEs from which the controls were derived; include the same organizations in the review and approval process as those used for the CSEs; and be developed and controlled in accordance with laboratory procedures. Responsibility for implementation of all criticality controls resides with facility management.

\subsubsection{Engineered Controls}

Laboratory procedures provide for the evaluation of engineered controls as part of the criticality safety program, including geometry, spacing, and neutron absorbers (both fixed and soluble). The use of engineered controls is based on factors such as feasibility of implementation and cost. Engineering controls important to criticality safety, as well as equipment used to store, handle, transport, or process fissionable material, are evaluated to determine configuration management needs. Detailed descriptions of engineered controls selected as safety SSCs for criticality safety are provided in facility-specific DSAs. 
Idaho National Laboratory

\begin{tabular}{|c|lll|}
\hline CHAPTER 6 - PREVENTION OF & Identifier: & SAR-400 & \\
INADVERTENT CRITICALITY - INL & Revision: & 4 & \\
STANDARDIZED SAFETY ANALYSIS & Effective Date: & $05 / 17 / 11$ & Page: 6-7 of 6-10 \\
REPORT & & & \\
\hline
\end{tabular}

\subsubsection{Administrative Controls}

In addition to engineering controls, administrative controls that impose limits on fissionable material mass, moderator, reflector, concentration, and volume may be used to ensure criticality safety. Detailed descriptions of administrative controls elevated to a TSR for criticality safety are provided in facility-specific DSAs.

\subsubsection{Application of Double Contingency Principle}

The criticality safety principles and criteria that govern nuclear facility operations are contained in LRD-18001. The fundamental requirement for criticality safety is that before beginning a new operation with fissionable material, or before changing an existing operation, the entire process is determined to be subcritical under both normal and credible abnormal conditions. The double contingency principle is a tool used to develop criticality accident scenarios and identify the process conditions and parameters involved and the number of controls on each parameter necessary to obtain the desired margin of safety. The double contingency principle recommends that sufficient factors of safety be incorporated into design or procedures to require at least two unlikely, independent, and concurrent changes in process conditions before a criticality accident is possible. The double contingency principle is applied to criticality accident scenarios to determine the required engineered features and administrative controls needed to prevent an inadvertent criticality. The criticality process analysis is documented in CSEs and/or safety basis documents.

\subsection{Criticality Safety Program}

The purpose of the Criticality Safety program is to ensure that activities involving fissionable materials are conducted in such a way that a criticality accident is prevented and mitigated. The Criticality Safety program is described in program description document (PDD)-18001, "INL Criticality Safety Program. ${ }^{"}$ Laboratory management is responsible for establishing a Criticality Safety program and for assigning, delegating, and accepting overall responsibility for criticality safety. Laboratory management is also responsible for establishing a program that includes personnel trained and qualified in criticality safety, for ensuring that the program is documented, and that a means for monitoring the effectiveness of the program exists. Facility management is responsible for the safe operation of facilities containing fissionable material.

A criticality safety program exists and provides the requirements for processes that involve transport, handling, processing, and storage of fissionable material. The determination of program requirements has been delegated to the Criticality Safety Engineering Group, which has documented a program compliant with applicable regulations, DOE orders, and industry standards, and includes best-management practices (LRD-18001).

Areas or processes that require criticality safety controls are designated as Criticality Control Areas (CCAs). The Criticality Safety program requires that areas or processes that contain greater than $15 \mathrm{~g}$ of fissionable material be evaluated for designation as CCAs. The purpose of the CCA program is to identify:

- Areas where criticality controls are needed

- The types of controls required to prevent and mitigate an accident 
Idaho National Laboratory

\begin{tabular}{|c|lll|}
\hline CHAPTER 6 - PREVENTION OF & Identifier: & SAR-400 & \\
INADVERTENT CRITICALITY - INL & Revision: & 4 & \\
STANDARDIZED SAFETY ANALYSIS & Effective Date: & $05 / 17 / 11$ & Page: 6-8 of 6-10 \\
REPORT & & & \\
\hline
\end{tabular}

- The personnel responsible for the areas

- Training of personnel having line management responsibility for criticality safety.

There are two types of CCAs: "Mass" and "Procedure." Mass CCAs are controlled to less than half of the water-moderated and-reflected minimum critical mass. Procedure CCAs require facility-specific evaluation and controls. The CCA program is governed by Laboratory procedures.

\subsubsection{Criticality Safety Organization}

The Criticality Safety Engineering Department provides technical support to operations, and documents requirements for the Criticality Safety program. The Department is independent of facility line management, and performs many duties that include the following:

- Act as point of contact for all INL criticality safety issues

- Develop, document, and maintain an effective and compliant Criticality Safety program (documented in LRD-18001)

- Administer the CCA program and ensure that criticality controls are in place for facilities and operations involving significant quantities of fissionable material

- Maintain qualified staff and a calculational capability for criticality safety and criticality alarm detector evaluations

- Perform criticality safety evaluations using handbook data or computational tools that are validated with applicable experimental data to provide controls that can be implemented resulting in safe yet cost-effective fissionable material operations

- Assist in the development and approval of facility safety basis documents

- Perform criticality safety reviews and assessments of existing facilities and planned activities.

Additional criticality safety responsibilities of management, facility management, and the Criticality Safety staff are identified in LRD-18001.

\subsubsection{Criticality Safety Plans and Procedures}

The Criticality Safety program has an array of safety plans and procedures through which the program is implemented. Criticality Safety program requirements, safety evaluations, assessments, control identification, and implementation are conducted in accordance with controlled documents (see Chapter 12, "Procedures and Training," for discussion of document control processes). All fissionable material activities are conducted in accordance with approved operating procedures. The procedures include controls and limits specified in the criticality safety analysis and are approved and controlled by facility management. Procedures are supplemented with posted criticality safety limits, if required. Facilities equipped with Criticality Alarm Systems (CASs) have evacuation plans and procedures. Requirements and guidelines for responding to fires in CCAs are found in LRD-18001 and include consideration of the presence of moderators when developing overall response plans. 
Idaho National Laboratory

\begin{tabular}{|c|lll|}
\hline CHAPTER 6 - PREVENTION OF & Identifier: & SAR-400 & \\
INADVERTENT CRITICALITY - INL & Revision: & 4 & \\
STANDARDIZED SAFETY ANALYSIS & Effective Date: & $05 / 17 / 11$ & Page: 6-9 of 6-10 \\
REPORT & & & \\
\hline
\end{tabular}

\subsubsection{Criticality Safety Training}

Facility management ensures that all workers handling significant quantities of fissionable material (greater than $15 \mathrm{~g}$ and requiring criticality control), and their supervisors, receive fissionable material handler training. Training emphasizes that workers must understand and follow applicable procedural requirements. All workers handling significant quantities of fissionable material are trained as fissionable material handlers in accordance with the criticality safety training program requirements listed in LRD-18001. The Criticality Safety training program meets the requirements of DOE O 5480.20A, "Personnel Selection, Qualification and Training Requirements for DOE Nuclear Facilities." Criticality Safety personnel are qualified per DOE-STD-1135-99, "Guidance for Nuclear Criticality Safety Engineer Training and Qualification." ${ }^{\circ}$

\subsubsection{Determination of Operational Nuclear Criticality Limits}

Operational nuclear criticality limits are established based on the criticality safety principles, criteria, accepted handbook data, and criticality safety calculations as prescribed in LRD-18001 and governed by Laboratory procedures.

\subsubsection{Criticality Safety Inspections and Audits}

Criticality safety inspections and assessments are conducted per Criticality Safety program and Laboratory procedures in accordance with DOE orders and industry standards. Assessments are performed to determine the effectiveness of the Criticality Safety program and that process conditions have not been altered so as to affect criticality safety evaluations.

\subsubsection{Criticality Infraction Reporting and Follow-up}

A criticality infraction is defined as a noncompliance with a criticality safety control, or the lack thereof. Reporting and documenting criticality infractions that involve facility specific TSRs or safety SSCs is done in accordance with approved procedures and manuals that implement the requirements of DOE Manual 231.1-2, "Occurrence Reporting and Processing of Operations Information." All criticality control infractions, including those outside of facility-specific DSAs, are reviewed to determine if there has been a programmatic breakdown of the Criticality Safety program.

\subsection{Criticality Instrumentation}

Criticality detection and alarm systems are used to mitigate radiation exposures from an inadvertent criticality. Mitigation is provided by the evacuation of personnel in accordance with facility-specific emergency plans. Criticality detection monitors, alarm systems, computer controls, and other support equipment (such as an uninterruptible power supply) make up the criticality alarm systems. Criticality alarm systems are designed, operated, and maintained per the requirements of the referenced Standard ANSI/ANS-8.3-1997, "Criticality Accident Alarm System." "These requirements are listed in LRD-18001. The need for a CAS is determined in facility-specific DSA. Well-shielded facilities (e.g., spent fuel pools and shielded hot cells) do not require an alarm system. 
Idaho National Laboratory

\begin{tabular}{|c|lll|}
\hline CHAPTER 6 - PREVENTION OF & Identifier: & SAR-400 & \\
INADVERTENT CRITICALITY - INL & Revision: & 4 & \\
STANDARDIZED SAFETY ANALYSIS & Effective Date: & $05 / 17 / 11$ & Page: 6-10 of 6-10 \\
REPORT & & & \\
\hline
\end{tabular}

\subsection{References}

1. LRD-18001, "INL Criticality Safety Program Requirements Manual," current revision.

2. 10 CFR 830 , "Nuclear Safety Management," Code of Federal Regulations, Office of the Federal Register.

3. DOE O 420.1B, Chapter III, "Nuclear Criticality Safety," U.S. Department of Energy, current revision.

4. DOE-STD-3007-2007, "Guidelines for Preparing Criticality Safety Evaluations at Department of Energy Non-Reactor Nuclear Facilities," U.S. Department of Energy, current revision.

5. American National Standards Institute/American Nuclear Society (ANSI/ANS) 8 Series Standards, current revision.

6. PDD-18001, "INL Criticality Safety Program," current revision.

7. DOE O 5480.20A, "Personnel Selection, Qualification and Training Requirements for DOE Nuclear Facilities," U.S. Department of Energy, current revision.

8. DOE-STD-1135-99, "Guidance for Nuclear Criticality Safety Engineer Training and Qualification," U.S. Department of Energy, current revision.

9. DOE Manual 231.1-2, "Occurrence Reporting and Processing of Operations Information," U.S. Department of Energy, current revision.

10. ANSI/ANS-8.3-1997, "Criticality Accident Alarm System," American National Standards Institute/American Nuclear Society, current revision. 
Idaho National Laboratory

\section{LIST OF CRITICALITY SAFETY PROGRAM DOCUMENTS}

$\begin{array}{lll}\text { Identifier: } & \text { NS-18209 } \\ \text { Revision: } & 4 \\ \text { Effective Date: } & 12 / 09 / 11\end{array}$

Effective Date: 12/09/11

\begin{tabular}{|l|l|l|l|}
\hline Criticality Safety & List & & eCR Number: 600439 \\
\hline
\end{tabular}

Manual: NO Nuclear Safety Engineering

\section{LIST}

\begin{tabular}{|c|c|c|c|c|}
\hline Document ID & Document Title & $\begin{array}{l}\text { Document } \\
\text { Owner }\end{array}$ & Date & Revision \\
\hline PDD-18001 & $\begin{array}{l}\text { INL Criticality Safety Program } \\
\text { Description Document }\end{array}$ & J. T. Taylor & $07 / 12 / 10$ & 3 \\
\hline LRD-18001 & $\begin{array}{l}\text { INL Criticality Safety Program } \\
\text { Requirements Manual }\end{array}$ & J. T. Taylor & $03 / 30 / 10$ & 2 \\
\hline LWP-18003 & $\begin{array}{l}\text { Establishing, Operating, and } \\
\text { Deleting INL Criticality Control } \\
\text { Areas }\end{array}$ & J. T. Taylor & $09 / 30 / 10$ & 3 \\
\hline NS-18201 & $\begin{array}{l}\text { Performing and Reviewing } \\
\text { Criticality Safety Evaluations }\end{array}$ & J. T. Taylor & $07 / 06 / 10$ & 4 \\
\hline NS-18202 & Criticality Safety Assessments & J. T. Taylor & $10 / 17 / 11$ & 2 \\
\hline NS-18203 & $\begin{array}{l}\text { Criticality Safety Engineer } \\
\text { Qualification Plan }\end{array}$ & J. T. Taylor & $12 / 03 / 09$ & 1 \\
\hline NS-18204 & $\begin{array}{l}\text { Criticality Safety Officer } \\
\text { Qualification Plan }\end{array}$ & J. T. Taylor & $11 / 03 / 10$ & 3 \\
\hline NS- 18205 & $\begin{array}{l}\text { Criticality Safety Specialist } \\
\text { Qualification Plan }\end{array}$ & J. T. Taylor & $06 / 10 / 08$ & 1 \\
\hline NS-18209 & $\begin{array}{l}\text { List of Criticality Safety Program } \\
\text { Documents }\end{array}$ & J. T. Taylor & $12 / 09 / 11$ & 4 \\
\hline NS- 18210 & $\begin{array}{l}\text { Criticality Safety Program } \\
\text { Requirements Identification and } \\
\text { Implementation Document }\end{array}$ & J. T. Taylor & $03 / 30 / 10$ & 2 \\
\hline NS-18211 & Criticality Safety Analysis Software & J. T. Taylor & $10 / 26 / 10$ & 0 \\
\hline INL/EXT-06-01183 & $\begin{array}{l}\text { Criticality Safety Basics for INL } \\
\text { FMHs and CSOs }\end{array}$ & J. T. Taylor & $06 / 30 / 06$ & 0 \\
\hline INL/INT-06-01380 & $\begin{array}{l}\text { Criticality Dose Calculational } \\
\text { Methodology }\end{array}$ & J. T. Taylor & 09/08/09 & 1 \\
\hline INL/EXT-07-12535 & $\begin{array}{l}\text { Criticality Safety Basics for INL } \\
\text { Emergency Responders }\end{array}$ & J. T. Taylor & $05 / 31 / 07$ & 0 \\
\hline
\end{tabular}


Idaho National Laboratory

LIST OF CRITICALITY SAFETY PROGRAM DOCUMENTS

$\begin{array}{lll}\text { Identifier: } & \text { NS-18209 } \\ \text { Revision: } & 4 \\ \text { Effective Date: } & \text { 12/09/11 }\end{array}$
Revision: $\quad 4$

Page: 2 of 2

\begin{tabular}{|l|l|l|c|c|}
\hline \multicolumn{1}{|c|}{ Document ID } & \multicolumn{1}{|c|}{ Document Title } & $\begin{array}{c}\text { Document } \\
\text { Owner }\end{array}$ & \multicolumn{1}{c|}{ Date } & Revision \\
\hline INL/INT-10-19660 & $\begin{array}{l}\text { MCNP5 1,40 Verification and } \\
\text { Validation for the Criticality Safety } \\
\text { Analysis Software Application }\end{array}$ & J. T. Taylor & $10 / 25 / 10$ & 0 \\
\hline INL/INT-10-19661 & $\begin{array}{l}\text { MCNP5 1.51 Verification and } \\
\text { Validation for the Criticality Safety } \\
\text { Analysis Software Application }\end{array}$ & J. T. Taylor & $10 / 26 / 11$ & 1 \\
\hline INL/INT-11-22236 & $\begin{array}{l}\text { SCALE 6.0 Verification and } \\
\text { Validation for the Criticality Safety } \\
\text { Analysis Software Application }\end{array}$ & J. T. Taylor & $11 / 11 / 11$ & 1 \\
\hline
\end{tabular}


Rev. 01

Use with MCP-42

Page 1 of 8

MFC Nuclear Operations TRAINING DEPARTMENT

TRAINING DESIGN PLAN

FOR

SSPSF SAR 408/TSR 408 IMPLEMENTATION 2011

At

MFC

Revision: 00

Instructional Designer: Marianne Noy

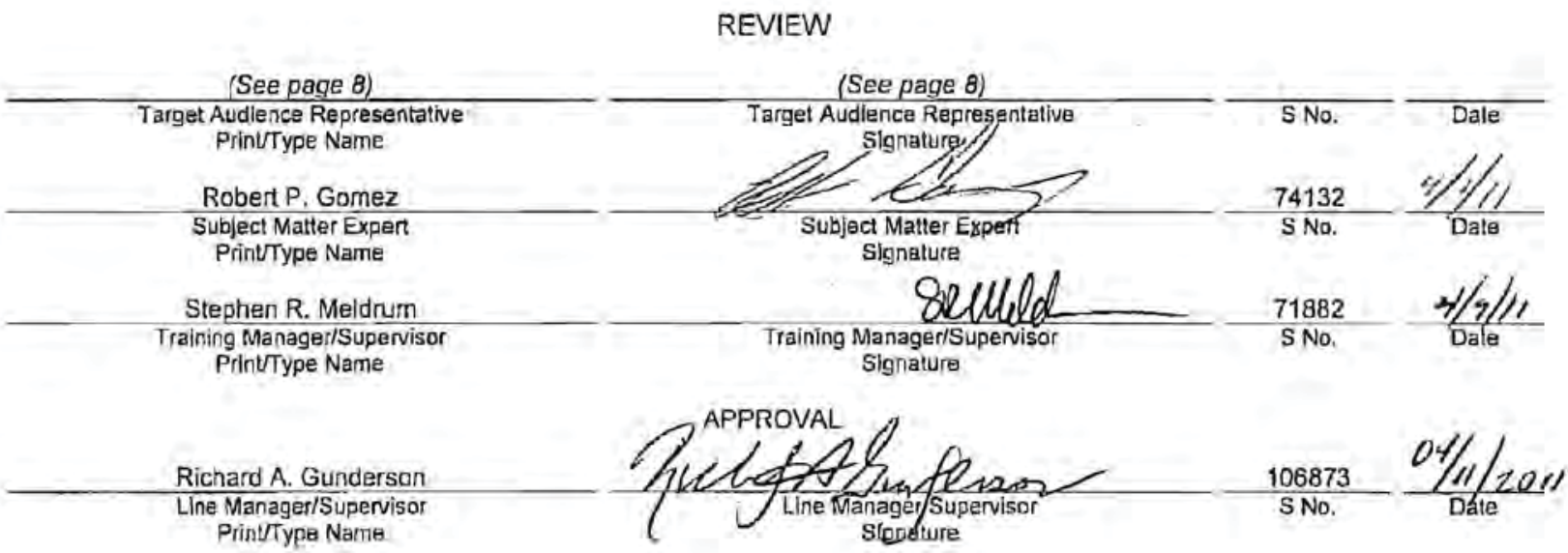


$361.73 A$

$09 / 20 / 2006$

Rev. 01

Use with MCP-42

TRAINING DESIGN PLAN

Submitted by:

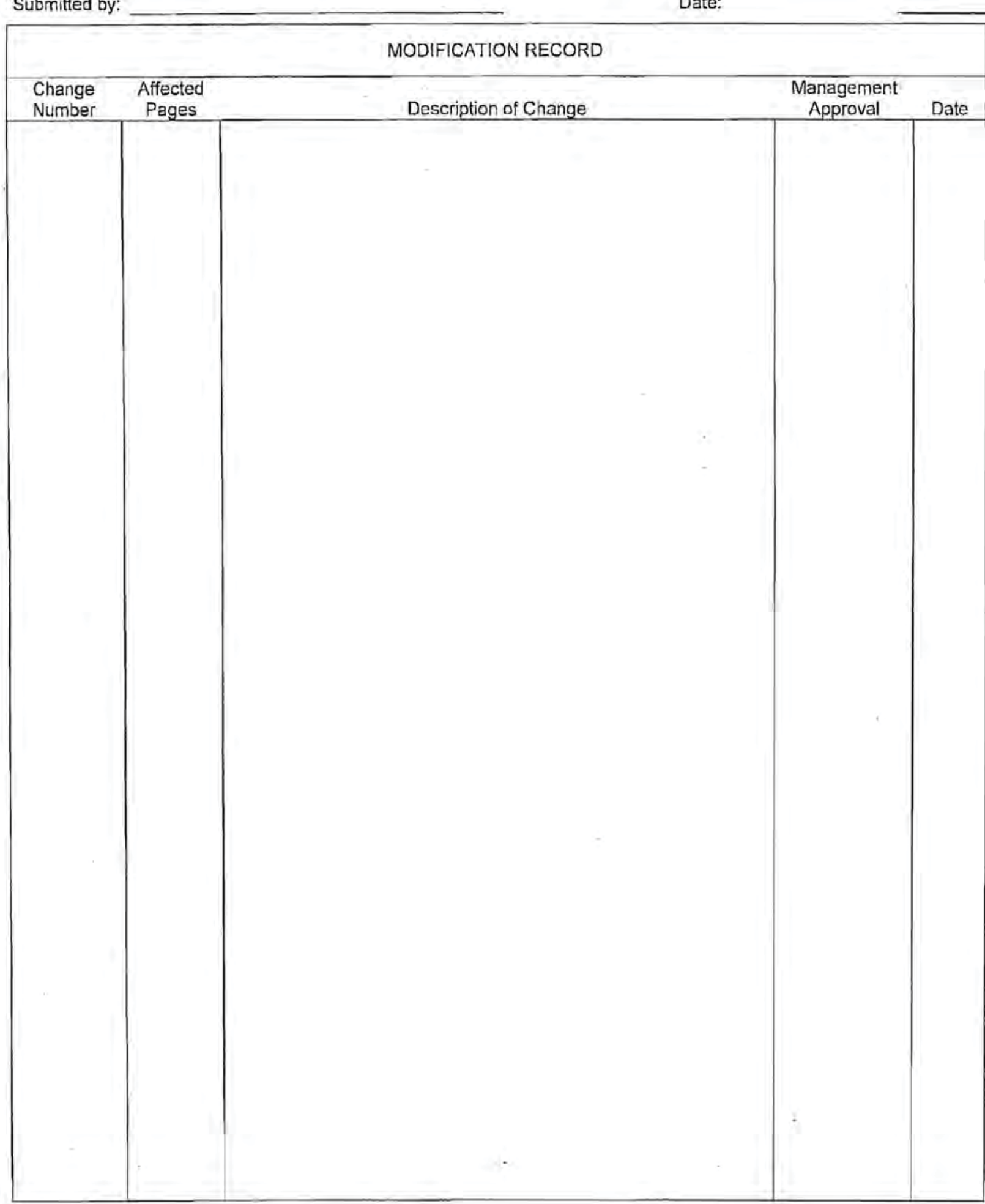

Page 2 of 8

Date: 
Rev. 01

Use with MCP-42

Introduction:

This design plan details the required training for implementation of Safety Analysis Report (SAR)-408 and Technical Safety Requirements (TSR)-408 for the Space \& Security Power Systems Faclity (SSPSF) at the Materials and Fuels Complex (MFC). As a part of implementation, training for INL. Standardized SAR-400/TSR-400 and INL/INT-09-16013, SSPSF Criticality Safety Evaluation revision, as applicable, is also detailed in this plan.

Training Program Title:

SSPSF SAR-408/TSR-408 Implementation

Drivers:

DOE Order 426.2, "Personnel Selection, Training, Qualification, and Certification Requirements for DOE Nuclear Facilitles" (formerly DOE Order 5480.20A)

PDD-147, "MFC Nuclear Facility Training Program"

Prerequisites:

Nuclear Facility Personnel:

Nuclear Facility Operations Personnel as defined by DOE Order 426.2, i.e., Nuclear Facility Managers, Operations Supervisors, Technical Staff, Operators, Facility Shift Supervisor, Maintenance, Technicians (RPS Quality Inspectors, MFC Mechanics, I\&C Technicians), and instructors will meet the existing requirements for training and qualification prescribed by PDD-147, "MFC Nuclear Facility Training Program," and their individual training plans. Health Physics Technicians (HPT) will meet the requirements of PDD-1073, "Radiological Control Training and Qualifications Programs." USQ managers and evaluators will meet the requirements of the USQ training program. Other nuclear facility personnel (Safeguards and Security, and MBA custodians, and maintenance) will meet the training and qualification requirements as identified in their training plans and programs.

Objectives:

The specific objectives will be covered as identified in the attached matrix, "DSA-009-RPSF to SAR/TSR-408 Crosswalk and Training Analysis/Design." 
Rev. 01

Use with MCP-42

Mastery of Objectives:

The required training will be tracked to completion.

SSPSF Operator/Foreman/SS:

Mastery of objectives will be measured by written examinations on TSRs and criticality controls. At least minimum staffing personnel must complete the required training prior to SAR/TSR-408 implementation. Individuals must demonstrate $100 \%$ completion prior to performing work that is impacted by the changes. Training will track the completion of training by using a qualified watch list.

Management, Technical Staff, RPS Quality Inspectors, RPS Quality Engineers, Maintenance, Support Staff, USQ, Safety Analysts, HPTs, MBA Custodians:

Mastery of objectives will be demonstrated by satisfactory participation in the assigned training as identified. At a minimum, personnel assigned to SSPSF facility must complete the required training prior to implementation or prior to perfoming work in or related to SSPSF.

Safeguards:

Safeguards tralning coordinators will address training needs for the safeguards personnel as applicable.

NOTE 1: SSPSF Technical Lead are assigned functions filled by SSPSF operators and supervisors. RPS SME are assigned functions filled by RPS Engineers (SSPSF Technical Staff). Neither of these fundtions are identified within the plan because the required training is identified by position (operator, supervisor, RPS engineer, etc).

NOTE 2: RPS Quality Assurance consists of quality inspectors (RPS QI) and quality engineers (RPS QE). Unless specified, RPS QA refers to both.

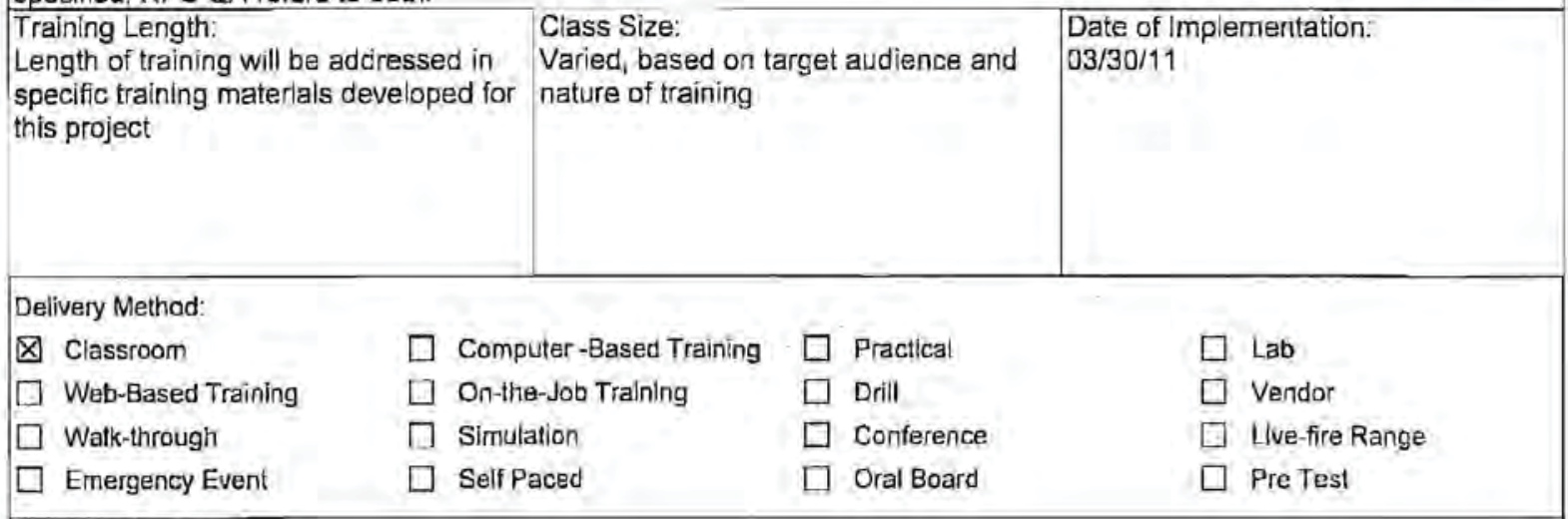

Program Content:

The Iraining program and content will ensure personnel are knowledgeable and are competent commensurate with their responsibilities. Furthermore, the program will include, as applicable, facility-specific training, safety tralning, training to new project-specific procedures, training to the safety basis, and training for abnormal conditions. The training will be reviewed to ensure it adequately addresses all aspects of the planned operations. The training plan will meet the requirements of Manual 12, PDD-147, and LWP-12061.

After analysis, it was determined that the training will take five training sessions. The analysis, implementing documents, target audiences, specific objectives, and applicable training are identified in the attached matrices. See "SSPSF SAR/TSR-408 Related Training Implementation Matrix," and "DSA-009-RPSF to SAR/TSR-408 Crosswalk and Training Analysis / Design."

MCS1102D

The generic lesson plan MFC00014. "MFC DSA/TSR Revision/Update," will be used to deliver training covering the INL Standardized DSAVTSR, SAR-400/TSR-400. For this training, Objective 1 and Objective 3 will be used. No written examination will be given 
Rev. 01

Use with MCP-42

The generic lesson plan MFC00014, "MFC DSATSR Revision/Update," will be used to deliver training covering SAR-408 TSR 408 , and associated changes. For this training, the following objectives will be used. There will be a written examination."

1. Review of the INL Slandardized Nuclear Safety Basis Manual (SAR-40O) (Brief Overview Only)

1.1 DISCUSS the use and application of INL Standardized Nuclear Safety Basis Manual; (SAR-400)

1.2 REVIEWI DISCUSS each chapter of SAR-400

2. Facility Specific DSA Changes:

2.1 DISCUSS the changes to the DSA (20 Chapters)

2.2 DISCUSS the bases for changes to the DSA

2.3 DISCUSS the relationship between the facility's DSASAR documents (SAR-400 and the facility specific DSA)

3. Will Not Use

4. Facility Specific TSR Changes:

4.1 DISCUSS the bases for changes to the TSR

4.2 DISCUSS the relationship between the facility's TSR documents (TSR-400 and the facility -specific TSR)

4.3 DISCUSS the changes to the Use and Application section in the Technical Safety Requirements

4.7 DESCRIBE the changes to the Administrative Controls (ACs) in the Technical Safety Requirements

4.8 DESCRIBE the changes to the Design Features in the Technical Safety Requirements

5. Facility Specific Procedure/Forms changes due to the DSAITSR revision:

5.1 DISCUSS the changes to the facillty's procedures (l.e., NRAD-OL-5100, "Reactor Operations").

5.2 DISCUSS the changes to the facility's forms (i.e., Surveillance Checks).

NOTE: The following lists cover material contained in the SAR/TSR. They will be mentioned at an overview leve during this training: LST-677, "Radioactive Materlal Form Control for SSPSF;" LST-302, "Safety Basis List for the Materials and Fuels Complex (MFC) Space and Security Power Systems (SSPSF);" LST-324, "SSPSF Nuclear Safety Basis Implementation Matrix;" and IAG-261, "INL Authorization Agreement for the Materials and Fuels Complex (MFC) Space and Security Power Systems Facility (SSPSF)"

\section{MCS1102B}

The generic lesson plan MFC00013, "MFC Operating Procedure Review, " will be used to review the changes to SSPSFOI-21160, "SSPSF Nuclear Material Handling," and to discuss LST-395, "Criticality Safety Controls for SSPSF," (and applicable portions of INLINT-09-16013, "SSPSF Criticality Safety Evaluation"). For this training, the following objectives will be used. There will be a written examination.*

1. State the "W Questions" that should be understood while working through a procedure.

2. Identify the Purpose, Scope and Applicability of the procedure.

3. Discuss the safety hazards and speciflc precautions, prerequisites or limitations associated with the task/procedure.

5. Describe the basic steps of the procedure for the task. (Include cautions, notes, or other limitations and any reactivity effects).

6. Identify any Operational Safety Requirements, Technical Safety Requirements, UFSAR or other related safety bases items in the procedure.

8. Discuss the consequences of failing to adequately perform the task/evolution properly.

MCS1102C

The generic lesson plan MFC00061, "MFC Administrative Procedure/Document Review," will be used to discuss applicable sections of INLINT-09-16013 (primarily chapter 7) with the Fissionable Material Handler Supervisors (FMHS). For this training, the following objectives will be used. There will be a written examination.

1. Describe document scope.

2. Describe document applicability.

3. Describe document basis.

5. Discuss facility/organization activities when this document/procedure is required to be used,

6. State/identify the rules and regulations contained in the document/procedure that are applicable to the facility.

8 . Discuss the consequences of failing to adequately adhere to the procedure/document requirements.

9. Discuss actions to be taken when this procedure cannot be completed as written.

10. Discuss the rules associated with using this type of procedure.

"The written examination will only be required for operators, supervisors, and FMH/FMHS. The exam questions ior each training session identlied above will be combined into one examination.

Required Read 
An overview of the changes will be provided for USQ Managers and Evaluators as well as technical staff as identified in the attached matrices.

In addition to the five sessions outlined above, the Inltial training for SSPSF certified Fissionable Material Handlers (FMH) and FMHS needs to be reviewed. The FMH program also needs to be reviewed by INL Criticality Safety. INL/INT-0916013, "SSPSF Criticality Safety Evaluation," has been rewritten, and the FMH/FMHS initial training program for a needs to be reviewed from a 'knowledge of the CSE' perspective. Initlal analysis indicated that there are no additional tasks, nor any obsolete tasks, as a result of the CSE or SAR/TSR-408. However, the performance of some tasks will change, Assumptions:

- Safeguards and security training are the responsibility of the Safeguards and Security Training department.

- Availability of approved revised procedures with lead time to develop and deliver the training.

- Departments providing support staff, L.e, HPT, Maintenance, etc., have the responsibillty to ensure that assigned personne are trained/quallied to thair job positions prior to the performance of their support functions assoc/ated with this project.

- Personnel who were significantly involved with the development of SAR/TSR-408 and revision/creation of implementing procedures, will be given an exception to tralning as applicable.

- Personnel who were involved in the development and/or approval of the exam questions will also be considered for exemptions from written exams as applicable.

\section{Critical Success Factors:}

- Approved documents/procedures are available to the instructor prior to the development and delivery af identified training.

- Appropriato level review personnel are avallable to review training

- Assigned personnel satisfy prerequisite requlrements.

\section{Responsibilitiles and Roles:}

- See PDD-147 "MFC Nuclear Operations Training" for complete detalls.

- SP-20.1.1, "Laboratory and Hot Cells Services Roles and Responsibilities," identifies the roles and responsibilities of personnel assigned to these departments.

- R1037-0008-QP, "Radioisotope Power Systems Program (RPS) Quality Assurance Program Plan," identifies the responslbillties of personnel assigned to RPS in conjunction with SSPSF

- Line management has the ultimate responsibility to ensure that their personnel are adequately trained to perform their job in a safe and efficient manner.

- The training department exists to assist line management in camying out their training responsibilitles.

- Development of trainlng materials will be done by the SARTSR-408 implementation Coordinalor working with the fraining organization to ensure training is developed in accordance with approved training procedures. Input and review will be oblained from subject matler experts, as applicable, and approval by line management. Approved MFC template lesson plans will be used as appropriate.

- Qualified training personnel, subject matter experts, or management personnel will present training and be involved in the evaluation process.

- Line management will verify that personnel are adequately trained to periorm the work.

The Nuclear Facillty Manager for SSPSF or his alternate are considered Subject Matter Experts for this process, based on their extensive involvement with SAR/TSR-408 and process procedure development.

Retraining:

- Retraining of procedure changes is not specifically required. Retraining on the related tasks will be as determined by the biennial and continuing training process for SSPSF and RPS.

Materlals:

Presentatlons, examinations, qualification cards, etc, developed per the requirements of this plan.

Gomments:

None 
Other:

Post Training Considerations:

- The EDMS End User Notification System will be used to inform appropriate personnel of changes to procedures.

- Significant changes to the procedures will be analyzed to determine need for additional training. 
$361.73 \mathrm{~A}$

$09 / 20 / 2006$

Rev. 01

Use wilh MCP-42

Attendees of Design Meeling:

\begin{tabular}{|c|c|c|c|c|c|}
\hline Print Name: & Robert P. Gomez & Signature: & & S No.: & 74132 \\
\hline & $\begin{array}{l}\text { SARTTSR-408 } \\
\text { Implementation }\end{array}$ & & & & \\
\hline Job Tille: & Coordinator & Phone No.: & $533-8088$ & Mail Stop: & 6116 \\
\hline Print Name: & Marianne Noy & Signature: & & & 52771 \\
\hline Job Tille: & Instruclor & Phone No.: & $533-7560$ & Mail Stop: & 6112 \\
\hline
\end{tabular}

Review:

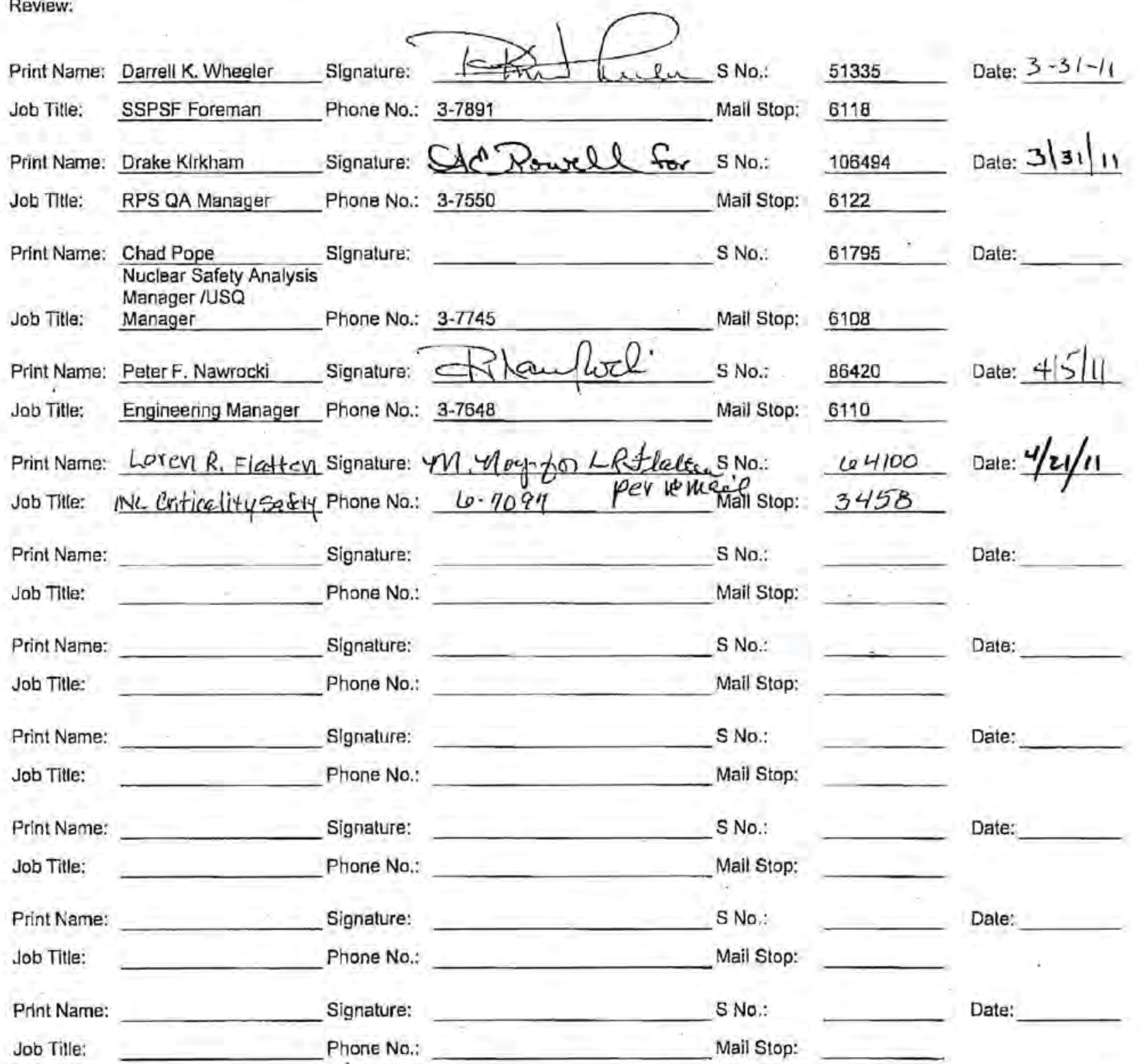

Page 8 of 8

Date: $4 / 1 / 16$

प Date: $4 / 1 / 1 /$

\section{TRAINING DESIGN PLAN}




\title{
Nuclear Infrastructure Assessment and Disablement Course (NIAD)
}

\section{Module \#3: Criticality Safety}

\author{
J. Todd Taylor
}

April 26, 2011 


\section{Applied Science of Criticality Safety}

\section{Todd Taylor}

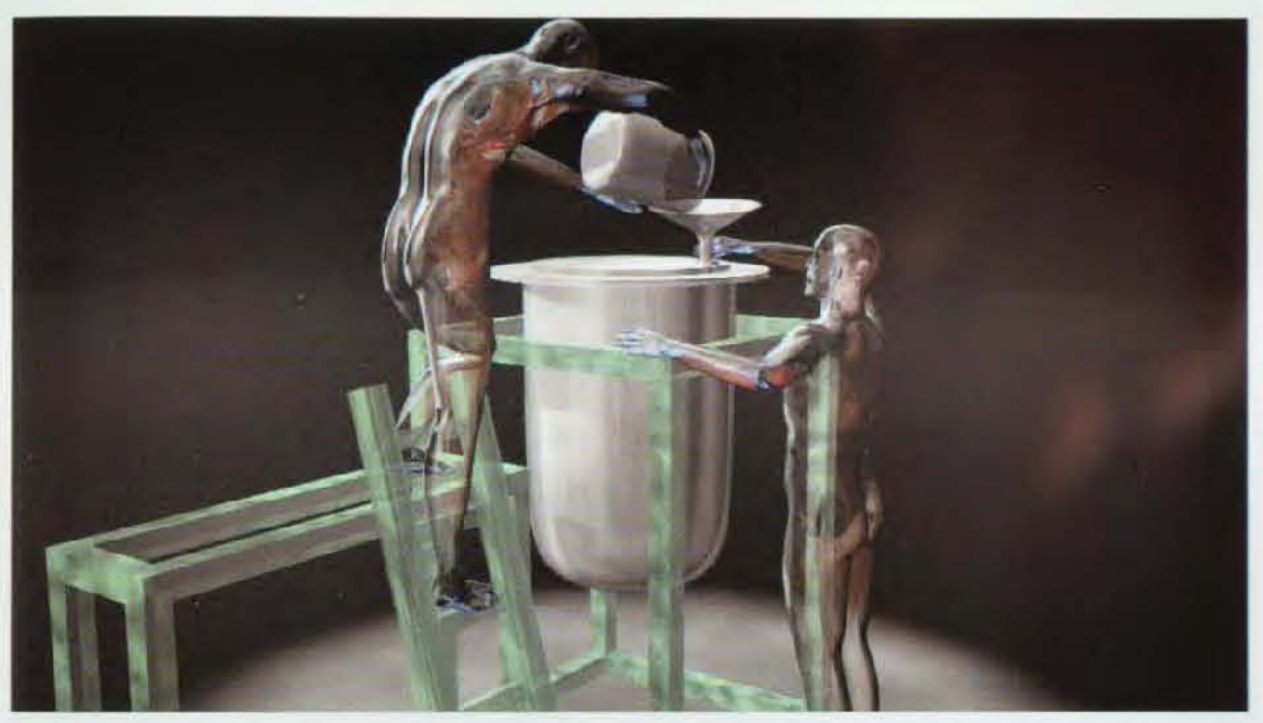

1 Working conditions at the time of the accident. Ouchi was supporting the funnel used to pour the uranium solution. Masato Shinohara, who was pouring the solution, was also exposed to a high dose of neutron beam radiation. 


\section{Reports Issued in 2011}

\begin{tabular}{|c|c|c|c|}
\hline Author & Report Number & Title & Date \\
\hline $\begin{array}{l}\text { J. J. Plowman } \\
\text { P. J. Sentieri }\end{array}$ & $\begin{array}{l}\text { INL/INT-07-13228 } \\
\text { Rev. } 1\end{array}$ & $\begin{array}{l}\text { Criticality Safety Evaluation for the Handling, } \\
\text { Storage and Inter-Facility Transfer of SNL } \\
\text { Transport Canisters Housing Test Assemblies }\end{array}$ & $01 / 19 / 11$ \\
\hline J. J. Plowman & INL/INT-11-21023 & $\begin{array}{l}\text { Criticality Safety Evaluation of SNL Transport } \\
\text { Canisters in ZPPR or FMF Vault }\end{array}$ & $02 / 03 / 11$ \\
\hline C. E. Stuart & $\begin{array}{l}\text { INL/INT-09-15665 } \\
\text { Rev. } 3\end{array}$ & $\begin{array}{l}\text { Criticality Safety Evaluation of the Uranium } \\
\text { Holdup in the Equipment Filters at FMF }\end{array}$ & $02 / 17 / 11$ \\
\hline C. E. Stuart & $\begin{array}{l}\text { EDF-6824 } \\
\text { Rev. } 3\end{array}$ & $\begin{array}{l}\text { Criticality Safety Evaluation for Handling } \\
\text { Fissionable Material Containers at the Fuel } \\
\text { Manufacturing Facility (FMF) }\end{array}$ & $02 / 17 / 11$ \\
\hline P. J. Sentieri & INL/INT-11-21186 & $\begin{array}{l}\text { Use of the Hydraulic Actuated Cutter in the Fuel } \\
\text { Conditioning Facility (FCF) }\end{array}$ & $03 / 02 / 11$ \\
\hline N. J. Schira & INL/INT-11-20982 & $\begin{array}{l}\text { Criticality Safety Evaluation for the DTRA Low- } \\
\text { Enriched Uranium Inspection Object }\end{array}$ & $03 / 17 / 11$ \\
\hline $\begin{array}{l}\text { J. J. Plowman } \\
\text { V. L. Putman }\end{array}$ & INL/INT-11-21441 & $\begin{array}{l}\text { Criticality Safety Evaluation for the Storage of } \\
\text { the IPNS Source Cask }\end{array}$ & $03 / 21 / 11$ \\
\hline J. T. Taylor & $\begin{array}{l}\text { INL/INT-11-21528 } \\
\text { Rev. } 1\end{array}$ & $\begin{array}{l}\text { Criticality Safety Implementation Strategy for } \\
\text { the Metal Waste Form Furnace in HFEF }\end{array}$ & $\begin{array}{l}04 / 06 / 11 \\
07 / 27 / 11\end{array}$ \\
\hline C. E. Stuart & $\begin{array}{l}\text { ECAR-1486 } \\
\text { Rev. } 1 \\
\text { Rev. } 2\end{array}$ & $\begin{array}{l}\text { Criticality Safety Evaluation for the Storage and } \\
\text { Handling of EBR-II Fuel Bottles in the Fuel } \\
\text { Conditioning Facility at MFC }\end{array}$ & $\begin{array}{l}04 / 20 / 11 \\
08 / 11 / 11 \\
11 / 30 / 11\end{array}$ \\
\hline $\begin{array}{l}\text { L. M. Montierth } \\
\text { V. L. Putman }\end{array}$ & $\begin{array}{l}\text { INL/INT-11-22236 } \\
\text { Rev. } 1\end{array}$ & $\begin{array}{l}\text { SCALE 6.0 Verification and Validation for the } \\
\text { Criticality Safety Analysis Software Application }\end{array}$ & $\begin{array}{l}05 / 26 / 11 \\
11 / 07 / 11\end{array}$ \\
\hline C. E. Stuart & $\begin{array}{l}\text { INL/INT-09-15364 } \\
\text { Rev. } 2\end{array}$ & $\begin{array}{l}\text { Criticality Safety Evaluation for the Fuel } \\
\text { Accident Condition Simulator (FACS) Furnace } \\
\text { in the Hot Fuel Examination Facility (HFEF) }\end{array}$ & $06 / 28 / 11$ \\
\hline P. J. Sentieri & TEV-1234 & $\begin{array}{l}\text { Technical Evaluation for the Receipt and } \\
\text { Processing of Alpha Gamma Hot Cell Material at } \\
\text { FCF }\end{array}$ & $07 / 13 / 11$ \\
\hline
\end{tabular}




\section{Reports Issued in 2011}

\begin{tabular}{|c|c|c|c|}
\hline Author & Report Number & Title & Date \\
\hline C. E. Stuart & ECAR-1508 & $\begin{array}{l}\text { Criticality Safety Evaluation for the Storage of } \\
\text { Fissionable Material in Mk-II and Cold Line } \\
\text { Birdcages }\end{array}$ & $08 / 19 / 11$ \\
\hline C. E. Stuart & ECAR-1526 & $\begin{array}{l}\text { Criticality Safety Evaluation for the Storage of } \\
\text { FFTF Fuel Elements in FAB Birdcages and } \\
\text { Model } 60 \text { Containers }\end{array}$ & $08 / 19 / 11$ \\
\hline W. W. Scates & ECAR-1550 & $\begin{array}{l}\text { Criticality Alarm System Evaluation for the Zero } \\
\text { Power Physics Reactor Facility }\end{array}$ & $08 / 19 / 11$ \\
\hline V. L. Putman & ECAR-1652 & $\begin{array}{l}\text { RSWF Criticality Scenarios with a Concrete } \\
\text { Shield Plug }\end{array}$ & $08 / 25 / 11$ \\
\hline N. Zhang & ECAR-1610 & $\begin{array}{l}\text { Criticality Safety Evaluation for the TREAT } \\
\text { Reactor Building }\end{array}$ & $08 / 31 / 11$ \\
\hline W. W. Scates & $\begin{array}{l}\text { EDF-6478 } \\
\text { Rev. } 3\end{array}$ & $\begin{array}{l}\text { Criticality Dose Evaluation for the Fuel } \\
\text { Manufacturing Facility }\end{array}$ & $10 / 31 / 11$ \\
\hline $\begin{array}{l}\text { L. M. Montierth } \\
\text { V. L. Putman }\end{array}$ & $\begin{array}{l}\text { INL/INT-10-19661 } \\
\text { Rev. } 1\end{array}$ & $\begin{array}{l}\text { MCNP5 } 1.51 \text { Verification and Validation for the } \\
\text { Criticality Safety Analysis Software Application }\end{array}$ & $10 / 26 / 11$ \\
\hline L. M. Montierth & $\begin{array}{l}\text { INL/INT-09-15366 } \\
\text { Rev. } 1\end{array}$ & $\begin{array}{l}\text { Criticality Safety Evaluation for the Inter-Facility } \\
\text { Transfer of PSCs in the HFEF-5 Cask }\end{array}$ & $11 / 01 / 11$ \\
\hline P. J. Sentieri & TEV-1359 & $\begin{array}{l}\text { Technical Evaluation for Condensate to Return } \\
\text { to the Mk-V ER at FCF }\end{array}$ & $11 / 02 / 11$ \\
\hline $\begin{array}{l}\text { N. J. Schira } \\
\text { N. Zhang }\end{array}$ & ECAR-1711 & $\begin{array}{l}\text { Criticality Safety Evaluation of Fissionable } \\
\text { Material Equivalency Factors }\end{array}$ & $11 / 10 / 11$ \\
\hline W. W. Scates & ECAR-1718 & $\begin{array}{l}\text { Criticality Alarm System Evaluation for } \\
\text { CPP-651 }\end{array}$ & TBD \\
\hline W. W. Scates & ECAR-1720 & $\begin{array}{l}\text { Criticality Safety Evaluation for Building } \\
\text { CPP-651 }\end{array}$ & TBD \\
\hline C. E. Stuart & ECAR-1721 & $\begin{array}{l}\text { Criticality Safety Evaluation for the Storage of } \\
\text { Fissionable Material in Type 7A Drums }\end{array}$ & TBD \\
\hline
\end{tabular}

